Prepared in cooperation with the City of Lincoln

Microbe Concentrations, Laser Particle Counts, and Stable Hydrogen and Oxygen Isotope Ratios in Samples from a Riverbank Filtration Study, Platte River, Nebraska, 2002 to 2004

Data Series 133 



\section{Microbe Concentrations, Laser Particle Counts, and Stable Hydrogen and Oxygen Isotope Ratios in Samples from a Riverbank Filtration Study, Platte River, Nebraska, 2002 to 2004}

By J.R. Vogel, S.I. Harris, T.B. Coplen, E.W. Rice, and I.M. Verstraeten

Prepared in cooperation with the City of Lincoln

Data Series 133 


\section{U.S. Department of the Interior \\ Gale A. Norton, Secretary \\ U.S. Geological Survey \\ P. Patrick Leahy, Acting Director}

U.S. Geological Survey, Reston, Virginia: 2005

For sale by U.S. Geological Survey, Information Services
Box 25286, Denver Federal Center
Denver, CO 80225
For more information about the USGS and its products:
Telephone: 1-888-ASK-USGS
World Wide Web: http://www.usgs.gov/

Any use of trade, product, or firm names in this publication is for descriptive purposes only and does not imply endorsement by the U.S. Government.

Although this report is in the public domain, permission must be secured from the individual copyright owners to reproduce any copyrighted materials contained within this report.

Suggested citation:

Vogel, J.R. , Harris, S.I., Coplen, T.B., Rice, E.W., and Verstraeten, I.M. , 2005, Microbe Concentrations, Laser Particle Counts, and Stable Hydrogen and Oxygen Isotope Ratios in Samples from a Riverbank Filtration Study, Platte River, Nebraska, 2002 to 2004: U.S. Geological Survey, Data Series 133, 68 p. 


\section{Contents}

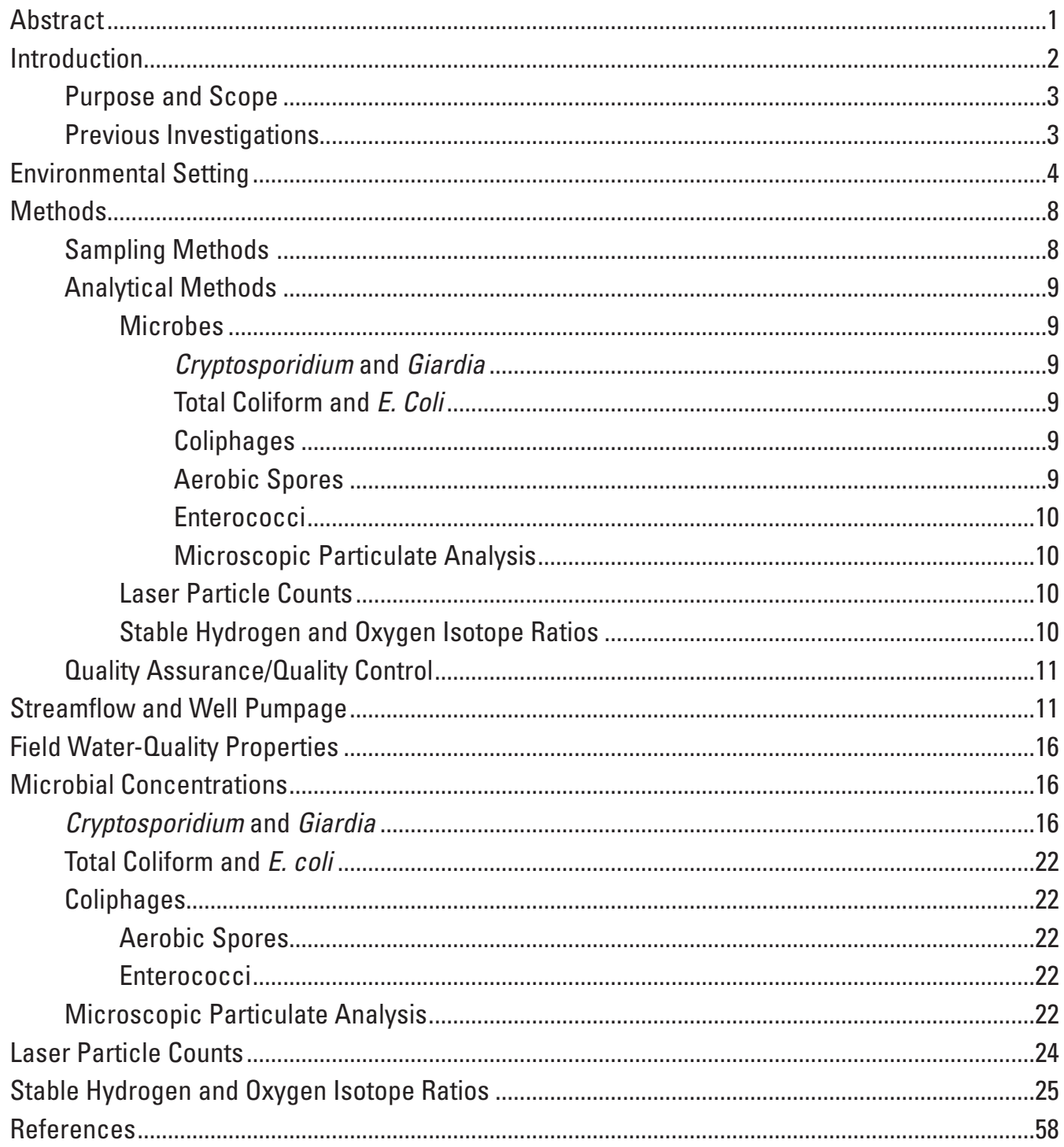

\section{Figures}

1. Location of the riverbank filtration study at a municipal well field along the Platte River in eastern Nebraska...

2. Comparison of average daily streamflow and historical mean daily streamflow at the Platte River near Ashland gaging station (06801000).

3. Flow conditions during sampling in the Platte River near Ashland between October 2002 and September 2004

4. Pumpage in collector well W90-1H during the period of the study................................15

5. Field water-quality properties at selected sites during the riverbank filtration study, Platte River, Nebraska. 


\section{Figures-Continued}

6. Turbidity at selected sites during the riverbank filtration study, Platte River, Nebraska.

7. Dissolved organic carbon (DOC) in samples from the Platte River and collector well W90-1H during the riverbank filtration study, Platte River, Nebraska.

8. Stable hydrogen and oxygen isotope ratios in samples from the Platte River and the well field during the riverbank filtration study, Platte River, Nebraska.

\section{Tables}

1. Description of microbes for which samples were analyzed during riverbank filtration study, Platte River, Nebraska.

2. Field water-quality properties and dissolved organic carbon in samples collected during the riverbank filtration study, Platte River, Nebraska

3. Percent recovery of dissolved organic carbon blind samples analyzed as part of the Organic Blind Sample Project by the National Water Quality Laboratory from February 23, 1999, to September 25, 2003.

4. Summary statistics of microbial concentrations in samples collected during riverbank filtration study, Platte River, Nebraska.

5. Cryptosporidium and Giardia concentrations in samples collected during the riverbank filtration study, Platte River, Nebraska.

6. Cryptosporidium and Giardia recovery efficiencies from analysis of samples during the riverbank filtration study, Platte River, Nebraska.

7. Total coliform, E. coli, male-specific and somatic coliphage, aerobic spore, and enterococci concentrations in samples collected during the riverbank filtration study, Platte River, Nebraska.

8. Summary statistics of microscopic particulate analysis concentrations in samples collected during riverbank filtration study, Platte River, Nebraska

9. Microscopic particulate analysis concentrations in samples collected during the riverbank filtration study, Platte River, Nebraska.

10. Summary statistics of laser particle counts in samples collected during riverbank filtration study, Platte River, Nebraska.

11. Laser particle counts in samples collected during the riverbank filtration study, Platte River, Nebraska.

12. Stable hydrogen and oxygen isotope ratios in samples collected during the riverbank filtration study, Platte River, Nebraska. 


\section{Conversion Factors and Datums}

\begin{tabular}{|c|c|c|}
\hline Multiply & By & To obtain \\
\hline \multicolumn{3}{|c|}{ Length } \\
\hline micrometer $(\mu \mathrm{m})$ & 0.00003937 & inch (in.) \\
\hline meter $(\mathrm{m})$ & 3.281 & foot $(\mathrm{ft})$ \\
\hline kilometer $(\mathrm{km})$ & 0.6214 & mile (mi) \\
\hline \multicolumn{3}{|c|}{ Volume } \\
\hline liter (L) & 33.82 & ounce, fluid (fl. oz) \\
\hline milliliter (mL) & 0.03382 & ounce, fluid (fl. oz) \\
\hline microliter $(\mu \mathrm{L})$ & 0.00003382 & ounce, fluid (fl. oz) \\
\hline liter $(\mathrm{L})$ & 2.113 & pint $(\mathrm{pt})$ \\
\hline liter (L) & 1.057 & quart (qt) \\
\hline liter (L) & 0.2642 & gallon (gal) \\
\hline \multicolumn{3}{|c|}{ Flow rate } \\
\hline cubic meter per second $\left(\mathrm{m}^{3} / \mathrm{s}\right)$ & 35.31 & cubic foot per second $\left(\mathrm{ft}^{3} / \mathrm{s}\right)$ \\
\hline cubic meter per day $\left(\mathrm{m}^{3} / \mathrm{d}\right)$ & 264.2 & gallon per day $(\mathrm{gal} / \mathrm{d})$ \\
\hline million liters per day (ML/d) & 0.2642 & million gallons per day $(\mathrm{Mgal} / \mathrm{d})$ \\
\hline cubic meter per second $\left(\mathrm{m}^{3} / \mathrm{s}\right)$ & 22.83 & million gallons per day $(\mathrm{Mgal} / \mathrm{d})$ \\
\hline \multicolumn{3}{|c|}{ Mass } \\
\hline nanogram (ng) & $3.527 \times 10^{-11}$ & ounce, avoirdupois (oz) \\
\hline microgram $(\mu \mathrm{g})$ & 0.00000003527 & ounce, avoirdupois (oz) \\
\hline milligram (mg) & 0.00003527 & ounce, avoirdupois (oz) \\
\hline $\operatorname{gram}(\mathrm{g})$ & 0.03527 & ounce, avoirdupois (oz) \\
\hline
\end{tabular}

Temperature in degrees Celsius $\left({ }^{\circ} \mathrm{C}\right)$ may be converted to degrees Fahrenheit $\left({ }^{\circ} \mathrm{F}\right)$ as follows:

$$
{ }^{\circ} \mathrm{F}=\left(1.8 x^{\circ} \mathrm{C}\right)+32
$$

Vertical coordinate information is referenced to the North American Vertical Datum of 1988 (NAVD 88).

Horizontal coordinate information is referenced to the North American Datum of 1983 (NAD 83).

Altitude, as used in this report, refers to distance above the vertical datum.

Specific conductance is given in microsiemens per centimeter at 25 degrees Celsius $(\mu \mathrm{S} / \mathrm{cm}$ at $\left.25^{\circ} \mathrm{C}\right)$.

Concentrations of chemical constituents in water are given either in milligrams per liter (mg/L) or micrograms per liter $(\mu \mathrm{g} / \mathrm{L})$. 



\title{
Microbe Concentrations, Laser Particle Counts, and Stable Hydrogen and Oxygen Isotope Ratios in Samples from a Riverbank Filtration Study, Platte River, Nebraska, 2002 to 2004
}

\author{
By J.R. Vogel, S.I. Harris, T.B. Coplen, E.W. Rice, and I.M. Verstraeten
}

\begin{abstract}
Riverbank filtration is an important process for removal of microbes, such as Cryptosporidium and Giardia, from ground waters affected by surface water. Water supplies identified as being ground water under the direct influence of surface waters are required to meet the same treatment requirements as surface water under the Surface Water Treatment Rule. Source waters that undergo riverbank filtration are after classified as ground water under the direct influence of surface water. Under many circumstances, however, environmental conditions and analytical techniques preclude direct quantification of removal of microbes of concern (Cryptosporidium and Giardia) during riverbank filtration. Instead, microbial and physical surrogates of these two protozoa that occur in greater concentrations and are less difficult to analyze for than Cryptosporidium and Giardia can be measured in the surface and ground waters in an attempt to quantify removal by riverbank filtration. To evaluate the use of riverbank filtration as an effective means of drinking-water treatment, a study was conducted from 2002 to 2004 by the U.S. Geological Survey, in cooperation with the City of Lincoln, at an established riverbank-filtration well field with horizontal collector wells and vertical wells. This report presents analytical methods and data collected during the study. Data are presented as generalized statistics and in figures showing temporal variations.

Sites from which water-quality samples were collected for this study included one surface-water site (Platte River), one ground-water site (W90-1H collector well), and two drinking-water sites (raw and finished). Samples from these sites were analyzed for field water-quality properties, microbe concentrations, laser particle counts, and stable hydrogen and oxygen ratios. Samples from an additional vertical well (W49-9) were analyzed for stable hydrogen and oxygen isotope ratios.

Cryptosporidium was detected in 48 percent (13 of 27) of Platte River samples collected during the study, and Giardia was detected in 44 percent (12 of 27) of Platte River samples collected during the study. Both microbes, however were not always detected in the same sample. In general, detected
\end{abstract}

Cryptosporidium concentrations were greater and more variable than Giardia concentrations. Neither Cryptosporidium nor Giardia was detected in any samples from well W90-1H, the raw water, or the finished water. Aerobic spores were detected in all samples collected from the Platte River and well W90-1H during this study. The mean concentration of aerobic spores in samples from the Platte River was 2.7 magnitudes greater than the mean concentration in samples from well W90-1H. Aerobic spores were detected in 95 percent of raw water samples and in 21 percent of finished water samples. Enterococci were detected in all samples from the Platte River, in one sample from well W90-1H, in one sample from the raw water, and in no samples from the finished water. During microscopic particulate analyses (MPAs), all non-diatomaceous algae were detected less frequently and at lower average concentrations in samples from well W90-1H than in samples from the Platte River except for Phacus. At least one type of diatom was detected in all samples from the Platte River. Unclassified diatoms were detected in 2 of 14 samples from well W90-1H, in 1 of 7 raw water samples, and in none of four finished water samples. Total coliforms were detected with decreasing frequency in samples from the Platte River, well W90-1H, and raw water, respectively, and not detected in finished water samples. E. coli were detected in most of the samples collected from the Platte River and in 9 percent of the samples collected from well W90-1H. E. coli were not detected in raw or finished water samples. In the Platte River, somatic coliphages were detected more often and generally in higher levels than male-specific coliphages. Somatic and male-specific coliphages were only detected at levels near the method detection limit in a few samples from well $\mathrm{W} 90-1 \mathrm{H}$, the raw water, and the finished water.

In general, mean laser particle counts in each size classification decreased as size increased. Mean laser particle counts in each size classification generally were greater in samples from the Platte River than in samples from well W90-1H and also generally were greater in the raw water than in the finished water. 
In surface water, stable hydrogen isotope ratios showed seasonal variations ranging from -73.1 per mill $(\% \circ)$ to $-48.7 \%$ relative to Vienna Standard Mean Ocean Water reference water, and stable oxygen isotope ratios varied from $-9.86 \%$ o to $-6.04 \%$. In ground water, stable hydrogen isotope ratios showed seasonal variations ranging from $-71.6 \%$ to $-45.0 \%$ relative to Vienna Standard Mean Ocean Water reference water, and stable oxygen isotope ratios varied from $-9.82 \%$ o to $-5.25 \%$ o.

\section{Introduction}

Bank filtration has been used for centuries to purify surface water. In its simplest form, a well is drilled near a body of water such as a stream or a lake. Vertical wells can be dug or drilled at varying distances from the surface-water source, and horizontal wells (also called collector wells) can have their laterals extending under a stream or lake. Stream or lake water flows through the sediments before entering the well. Depending on the soil characteristics, hydrologic conditions, and the distance water travels, high levels of pathogen removal can be achieved. However, water treatment efficiency for bank filtration depends on the specific hydrogeology of each well field.

Bank filtration offers some advantages over the conventional filtration methods for surface water, including reliability and low cost of operation. However, local conditions can affect the effectiveness of bank filtration. For example, sediment characteristics can affect both the retention time as well as the efficiency of the sediments in removing or disinfecting pathogens. Although indicators of disinfection completeness or filtration efficiency have been used widely and are well understood, indicators of bank filtration performance (for example, coliforms, turbidity, and particle size distributions) are less understood. Because most bank-filtered water of medium to large drinking-water treatment plants will be disinfected, the occurrence of pathogens that are susceptible to the disinfectants is not of high concern. However, for parasites, such as Cryptosporidium and Giardia, the commonly used drinkingwater disinfectants are not always effective.

Water supplies identified as being ground water under the direct influence (GWUDI) of surface waters are required to meet the same treatment requirements as surface water under the Surface Water Treatment Rule (SWTR) (U.S. Environmental Protection Agency, 2002). SWTR and subsequent surface-water regulations define GWUDI as "any water beneath the surface of the ground with (1) significant occurrence of insects or other macroorganisms, algae, or large diameter pathogens such as Cryptosporidium or Giardia, or (2) significant and relatively rapid shifts in water characteristics such as turbidity, temperature, conductivity, or $\mathrm{pH}$ which closely correlate to climatological or surface water conditions." State authorities determine GWUDI status using a combination of hydrogeologic criteria, sanitary surveys, well-construction logs, and analytical testing. In general, water from wells located near rivers and classified as GWUDI undergoes riverbank filtration. Two pathogens specifically regulated by the SWTR and subsequent surface water regulations are Cryptosporidium and Giardia. In Nebraska, precedent has been set at the Kearney, Nebraska, well field for the granting of removal credits for Giardia and Cryptosporidium if there is sufficient evidence of removal of these organisms by bank filtration processes (Elizabeth Esseks, Nebraska Department of Health and Human Services, oral commun., 2004).

Because Cryptosporidium oocysts and Giardia cysts commonly are present in river water, ineffective removal of these organisms by bank filtration could result in increased health risks. Historically, drinking-water quality is monitored by the presence or absence of indicator organisms (for example, coliforms and fecal coliform bacteria). Turbidity levels or particle counts are indicators of the efficacy of various filtration technologies in removing pathogens. Standard filtration performance can be studied by testing filter efficacy under laboratory, pilot plant, and field conditions. However, for bank filtration, each application has unique characteristics that may affect particle removal and pathogen disinfection. In theory, testing the drinking water for the presence of pathogens should be able to determine the safety of the water. However, methods to detect Cryptosporidium oocysts and Giardia cysts are particularly unreliable, generally recovering only a fraction of seeded oocysts/cysts (DiGiorgio and others, 2002). Limitations of the Cryptosporidium and Giardia tests indicate that failure to detect oocysts/cysts in drinking-water supplies does not ensure their absence in the water. Testing for various water-quality indicators may help to determine the presence of waterborne pathogens. However, comprehensive data are not yet available to determine which easily measured water-quality indicators can best assess either the presence of a pathogen or an increased health risk.

To understand the efficiency of riverbank filtration with respect to various microbes, more information is needed concerning the fate of contaminants as they move through the riverbed sediments into an aquifer and on to collector wells. A study was conducted from 2002 through 2004 at a riverbank filtration site on the Platte River in eastern Nebraska (fig. 1) by the U.S. Geological Survey (USGS), in cooperation with the City of Lincoln, to evaluate the use of riverbank filtration as an effective means of drinking-water treatment. During the study, water-quality samples were collected monthly or quarterly from the Platte River, a horizontal collector well, the influent (raw) water of a drinking-water treatment plant, and the finished water of a drinking-water treatment plant. The samples were analyzed for selected microbial concentrations, laser particle counts, and stable hydrogen and oxygen isotope ratios. Samples collected from a vertical well were also analyzed for stable hydrogen and oxygen isotope ratios. The objectives of this study were: (1) to evaluate the potential transport, attenuation, and inhibition of microorganisms of varying sizes during riverbank filtration into a public-water supply at varying flow regimes of the river during different times of the year, and (2) to evaluate the use of various microbiological and 


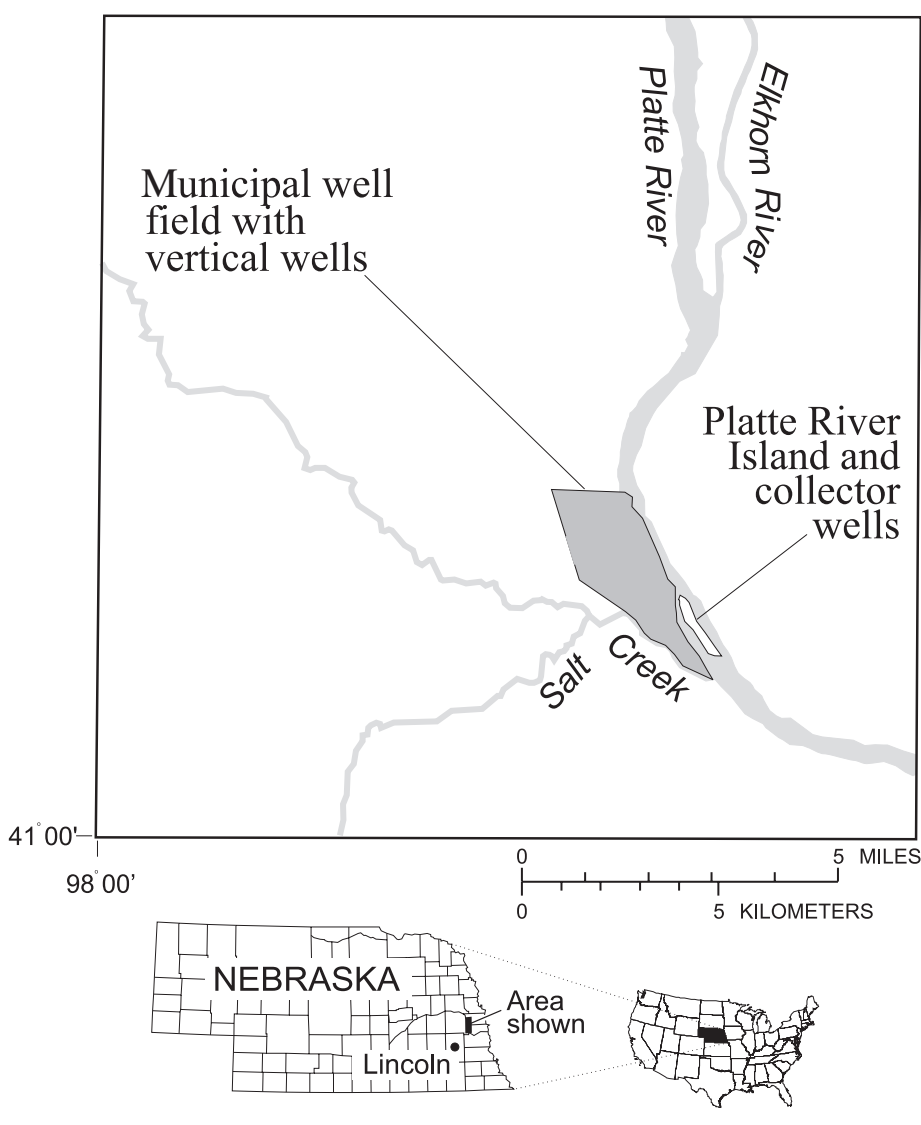

Figure 1. Location of the riverbank filtration study at a municipal well field along the Platte River in eastern Nebraska.

physical parameters as indicators of Cryptosporidium or Giardia contamination.

\section{Purpose and Scope}

The purpose of this report is to present field water-quality properties, microbe concentrations, laser particle counts, and stable hydrogen and oxygen isotope ratios in samples collected during a riverbank filtration study of the Platte River in eastern Nebraska during 2002 through 2004. This report includes descriptions of the sampling and analytical methods and data obtained during the study. Interpretations are limited to generalized statistics and figures containing temporal variations.

\section{Previous Investigations}

Previous studies have provided hydrologic background information and reasonable estimations of traveltimes and chemical transport velocities for the municipal well field monitored during this study (Davis, 1992; Verstraeten and others, 1998; Verstraeten and others, 1999; Heberer and others, 2001; Verstraeten and Heberer, 2002; Verstraeten, Heberer, and others, 2002; Verstraeten, Thurman, and others, 2002; Verstraeten, Heberer, and others, 2003; Vogel and others, 2005). However, these studies focused on chemical compound occurrence and transport at the research site.

Indicators or indicator organisms of Cryptosporidium and Giardia that may originate from similar sources and that were considered in this study include turbidity, particle counts, dissolved organic carbon, and microbial indicators (table 1). However, the absence of any or all of these indicators does not guarantee that Cryptosporidium or Giardia is not present (Aboytes and others, 2004).

Turbidity is a measure of suspended particulates in a liquid and has been linked to fecal contamination of surface and ground water (LeChevallier and others, 1991a; Christensen and others, 2001). LeChevallier and others (1991b) and LeChevallier and Norton (1992) indicate a link between log removal of turbidity and log removal of Cryptosporidium and Giardia. However, Rose and others (1988) did not find a direct correlation between turbidity and the presence of Cryptosporidium or Giardia in a watershed in the western United States.

Particle counts in specific size ranges have been used as an indication of filtration efficiency of Cryptosporidium and Giardia for conventional water-treatment plants. Studies indicate that log removal of particles evaluated in size ranges coincidental to the size of Cryptosporidium (4-7 $\mu \mathrm{m})$ and Giardia $(7-11 \mu \mathrm{m})$ can be used as a surrogate for log reduction of these organisms (LeChevallier and others, 1991b, LeChevallier and Norton, 1992; Nieminski and Ongerth, 1995). However, other research also has shown that the technology used in laser particle counters generally undersizes the particles (Lewis and Manz, 1991; Hargesheimer and others, 1992; O'Shaughnessy and others, 1997). Therefore, particle counts for slightly smaller particle-size ranges than those of the corresponding protozoa diameters have been used as surrogates for removal of these organisms.

Many studies have been completed using total or fecal coliforms as an indicator of fecal contamination (for example, Crane and others, 1983; Baxter-Potter and Gilliland, 1988; Mau and Pope, 1999; Fujioka and Yoneyama, 2001). Correlation of total coliform concentrations to Cryptosporidium or Giardia concentrations, however, has had mixed results. LeChevallier and others (1991a) indicated a statistical correlation between total coliform concentrations and Cryptosporidium and Giardia concentrations, whereas Akin and Jakubowski (1986), Rose and others (1988), and Boyer and Kuczynska (2003) did not. LeChevallier and others (1991a) pointed out that the maximum total coliform concentrations measured in their study were much higher than in Akin and Jakubowski (1986) and Rose and others (1988), indicating that the higher concentrations of total coliforms may be responsible for the higher correlations. For a river study in the western United States, Rose and others (1988) determined that total coliform and fecal coliform were not reliable predictors for the presence or absence of Cryptosporidium or Giardia. 
Francy and others (1994) and Edberg and others (1997) recommended using $E$. coli as an indicator of fecal contamination. Published literature reports the continued use of E. coli for this purpose (for example, Griffin and others, 1999; Fujioka and Yoneyama, 2001; Borst and Selvakumar, 2003; Haack and others, 2003). Thompson and Blatchley (2000) compared inactivation rates of E. coli and Cryptosporidium parvum by gamma irradiation, showing much larger levels of inactivation of E. coli than Cryptosporidium parvum at similar levels of gamma irradiation. E. coli has been shown to be unsuitable as a direct indicator of the presence of Cryptosporidium in streams because of faster die-off rates of E. coli than Cryptosporidium. Alm and others (2003) suggested that freshwater beach sand might also serve as a reservoir for fecal indicator bacteria such as E. coli.

Recent research has been completed using coliphages as an indicator of fecal contamination (International Association for Water Pollution Research and Control (IAWPRC) Study Group on Health Related Water Microbiology, 1991; Griffin and others, 1999; Fujioka and Yoneyama, 2001). Weiss and others (2003) indicated log reduction of various coliphages ranging from 1.9 to 3.3 at three drinking-water utilities in the midwestern United States during riverbank filtration. A male-specific coliphage (MS2) has been shown to have greater inactivation than Cryptosporidium parvum by similar levels of gamma irradiation during water treatment (Thompson and Blatchley, 2000). Chauret and others (1999) showed greater reduction of somatic coliphages than Cryptosporidium and Giardia during aerobic wastewater treatment (excluding the anaerobic sludge digestion). During the anaerobic sludge digestion, neither Cryptosporidium nor Giardia concentrations were reduced significantly, whereas the somatic coliphage concentration was reduced slightly.

Aerobic spores, specifically spores of the bacterium Bacillus subtilis, have been used as surrogates in evaluation of treatment processes with varying success (Facile and others, 2000; Chauret and others, 2001; Trimboli and others, 2001; Huck and others, 2002; Larson and Mariñas, 2003). Huck and others (2002) suggested that aerobic spores may be used in treatment plants as a conservative estimate of the capacity of the filter to remove Cryptosporidium under operating conditions based upon results from two treatment plants where removal of seeded Bacillus subtilis was lower than removal of seeded Cryptosporidium parvum. For disinfection purposes, Facile and others (2000) indicated that aerobic spores possibly could be used as a surrogate for inactivation of Giardia lamblia and Cryptosporidium parvum (oo)cysts during ozone activation. However, results from Larson and Mariñas (2003) and Craik and others (2002), indicated that Bacillus subtilis may not be a reliable surrogate of Cryptosporidium parvum inactivation for ozone disinfection. Aerobic spores have been found to be more sensitive than Cryptosporidium parvum to chlorine dioxide and chloramines and therefore may overestimate removal when used as a direct indicator of Cryptosporidium parvum inactivation in this process (Chauret and others, 2001; Larson and Mariñas, 2003).
Enterococci also have been used as an indicator of fecal contamination (Griffin and others, 1999; Vilanova and others, 2002; Haack and others, 2003). Enterococci generally seem to be more persistent than either bacterial pathogens or fecal coliforms (Cohen and Shuval, 1973; Davies-Colley and others, 1994; Sinton and others, 1994). Enterococci, however, may not be a good indicator of Cryptosporidium presence in river water because of higher die-off rates of enterococci compared to Cryptosporidium (Medema and others, 1997). Freshwater beach sands also may serve as a reservoir of enterococci and other fecal indicator bacteria (Alm and others, 2003). Results from Chauret and others (1999) showed greater reduction of enterococci than Cryptosporidium or Giardia during aerobic wastewater treatment (excluding the anaerobic sludge digestion). During the anaerobic sludge digestion, none of these three microbes were reduced significantly.

Microscopic particulate analysis (MPA) was developed by the U.S. Environmental Protection Agency (USEPA) to be used in determining whether an existing ground-water source should be classified as being under the influence of surface water (U.S. Environmental Protection Agency, 1992). MPAs have been used as a method to estimate the threat of groundwater contamination by Cryptosporidium and/or Giardia (Schulmeyer, 1994; Nnadi and Fulkerson, 2002). However, some studies caution about the overdependence on using the MPA as the only criteria for designating GWUDI without taking into account the absolute risk of illness from the water (Gollnitz and others, 1997; Chin and Qi, 2000). Quantitative MPA techniques also have been used to quantify concentrations of various indicator microbes including several types of non-diatomaceous algae, diatoms, rotifers, amoebae, nematodes, flagellates, and pollen (Schulmeyer, 1994).

\section{Environmental Setting}

The Platte River and its tributaries receive municipal waste from most cities along its course, except the City of Omaha, which releases its wastewater into the Missouri River above its confluence with the Platte River. Along the Platte River and its tributaries, an estimated 200 sewage treatment plants (STPs) release treated or untreated wastewater into the rivers with flows varying from about $0.4 \mathrm{ML} / \mathrm{d}$ (million liters per day) to about $200 \mathrm{ML} / \mathrm{d}$ (Ronald Ash, Nebraska Department of Environmental Quality, oral commun., 2001). In addition, more than an estimated 7,000 animal feeding operations (AFOs) exist in Nebraska, of which less than 1,000 are confined animal feeding operations (CAFOs). A CAFO is defined by the State of Nebraska as having at least 1,000 animal units (Dennis Heitmann, Nebraska Department of Environmental Quality, oral commun., 2001). The AFOs vary in size from more than 1 unit to almost 100,000 units of cattle and pigs. During runoff events or chronic wet periods (several rainfalls within 1 month leaving the soils saturated and standing water high in collection pits), unregulated and regulated 
discharges occur from these AFOs into nearby streams. Nebraska was ranked third on January 1, 2004, in inventory of cattle and calves in the United States with 6.25M (million) head, or about 6.6 percent of the national inventory (National Agricultural Statistics Service, 2004). Moreover, Nebraska was ranked seventh in the United States on December 1, 2003 , in inventory of hogs and pigs with about 2.9M head, or 4.8 percent of the national production (National Agricultural Statistics Service, 2004).

Table 1. Description of microbes for which samples were analyzed during riverbank filtration study, Platte River, Nebraska.

[um, micrometers; diam, diameter; ${ }^{\circ} \mathrm{C}$, degrees Celsius; --, not applicable]

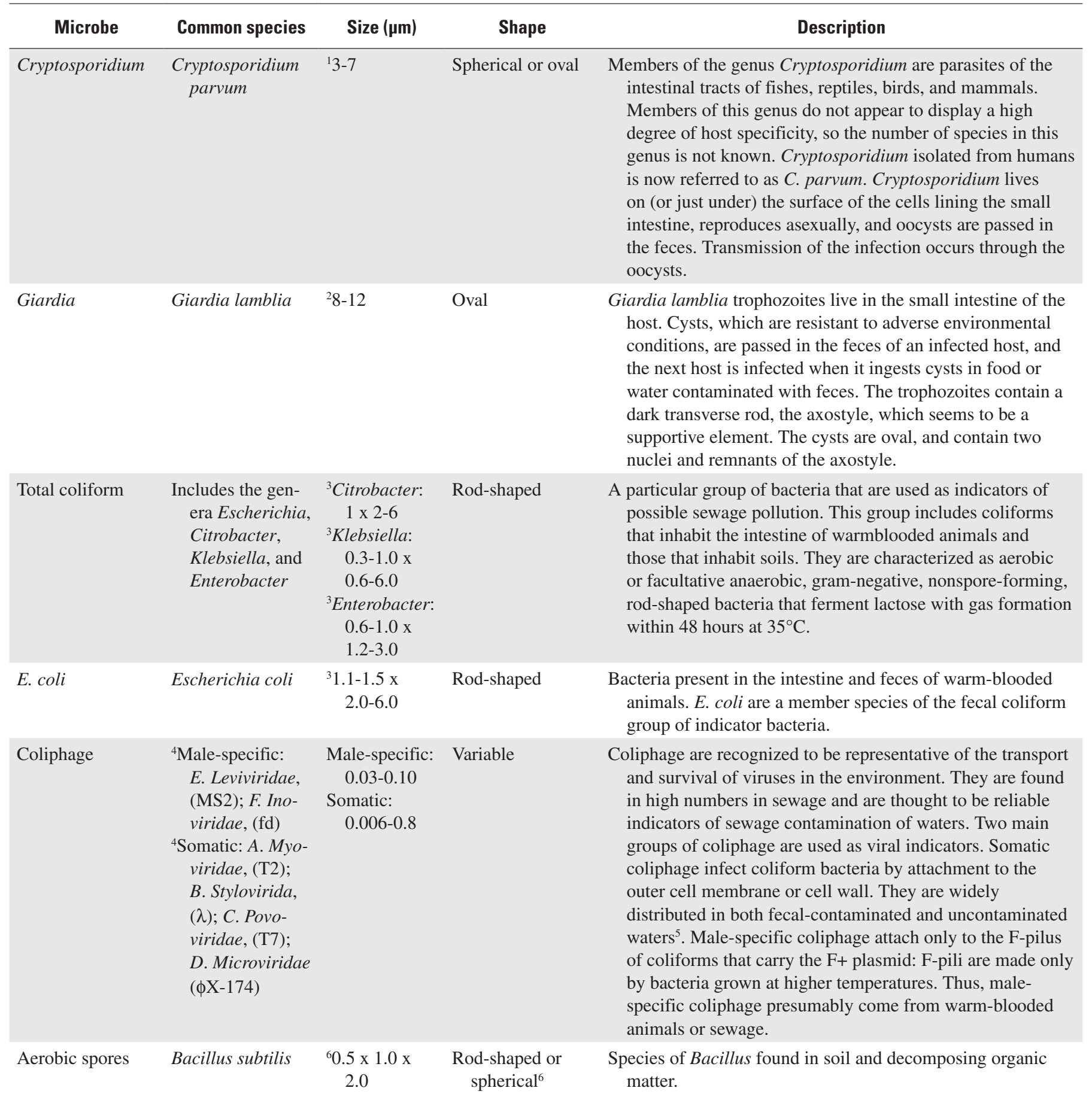


Table 1. Description of microbes for which samples were analyzed during riverbank filtration study, Platte River, Nebraska.Continued

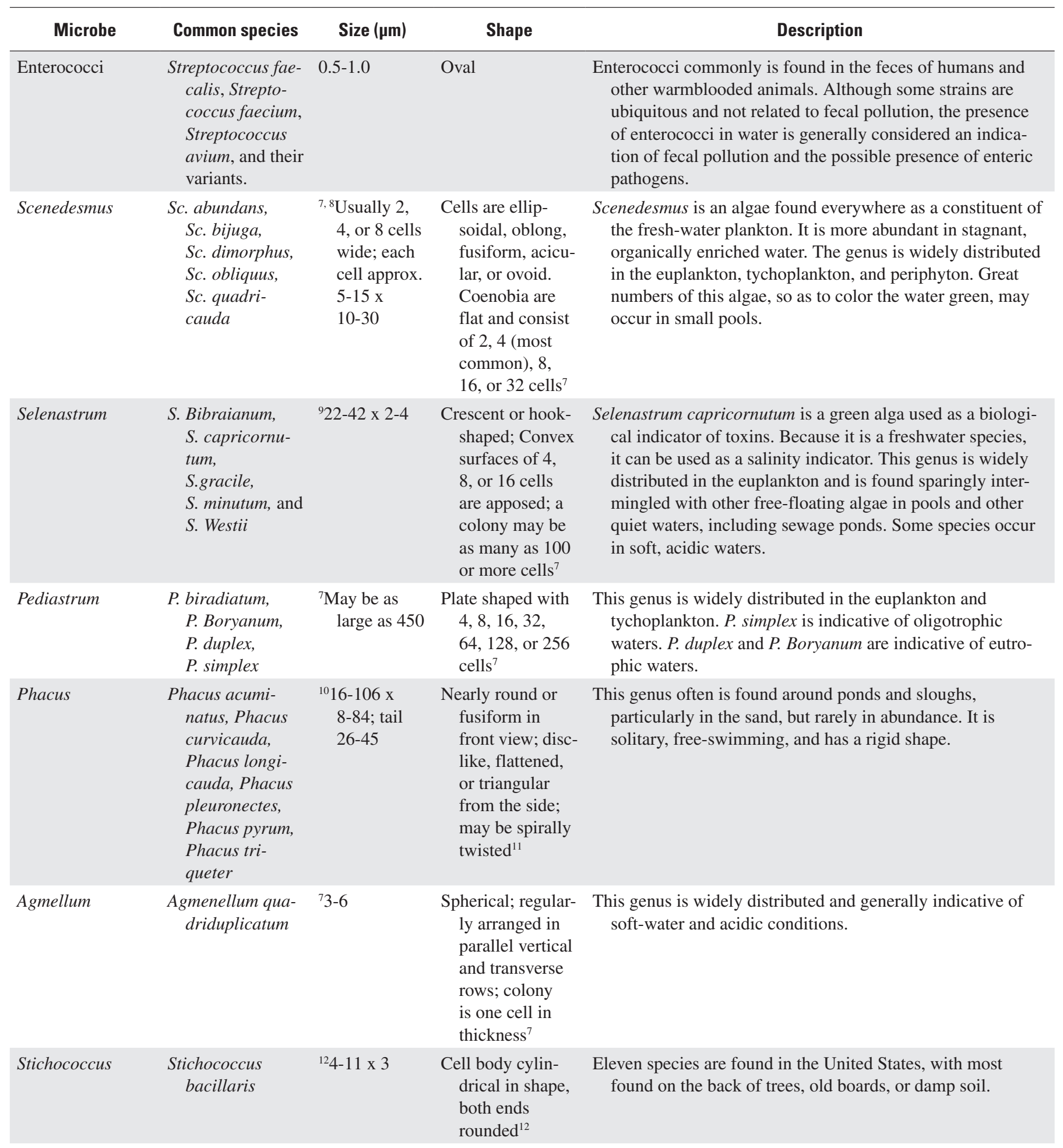


Table 1. Description of microbes for which samples were analyzed during riverbank filtration study, Platte River, Nebraska.Continued

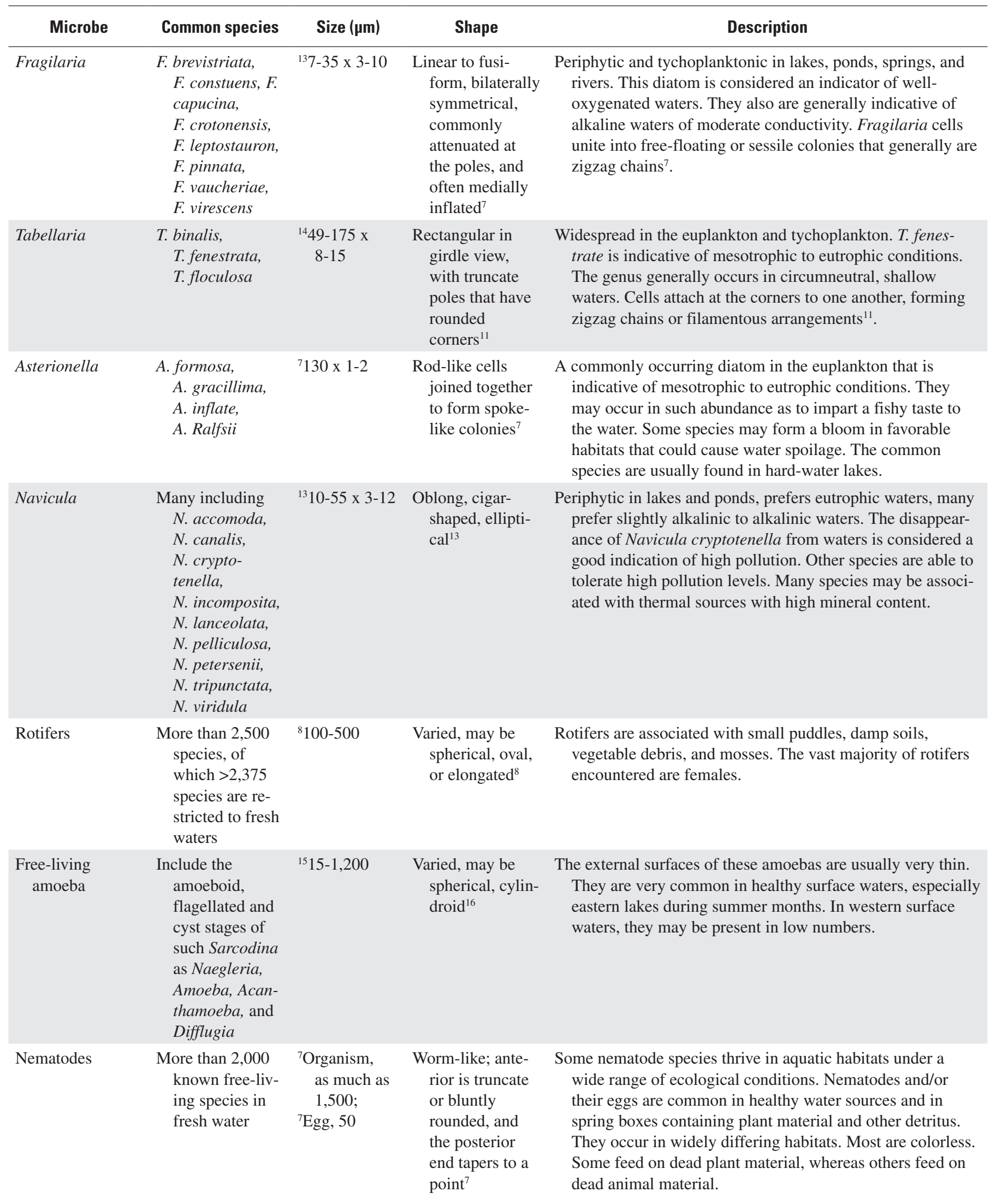


Table 1. Description of microbes for which samples were analyzed during riverbank filtration study, Platte River, Nebraska.Continued

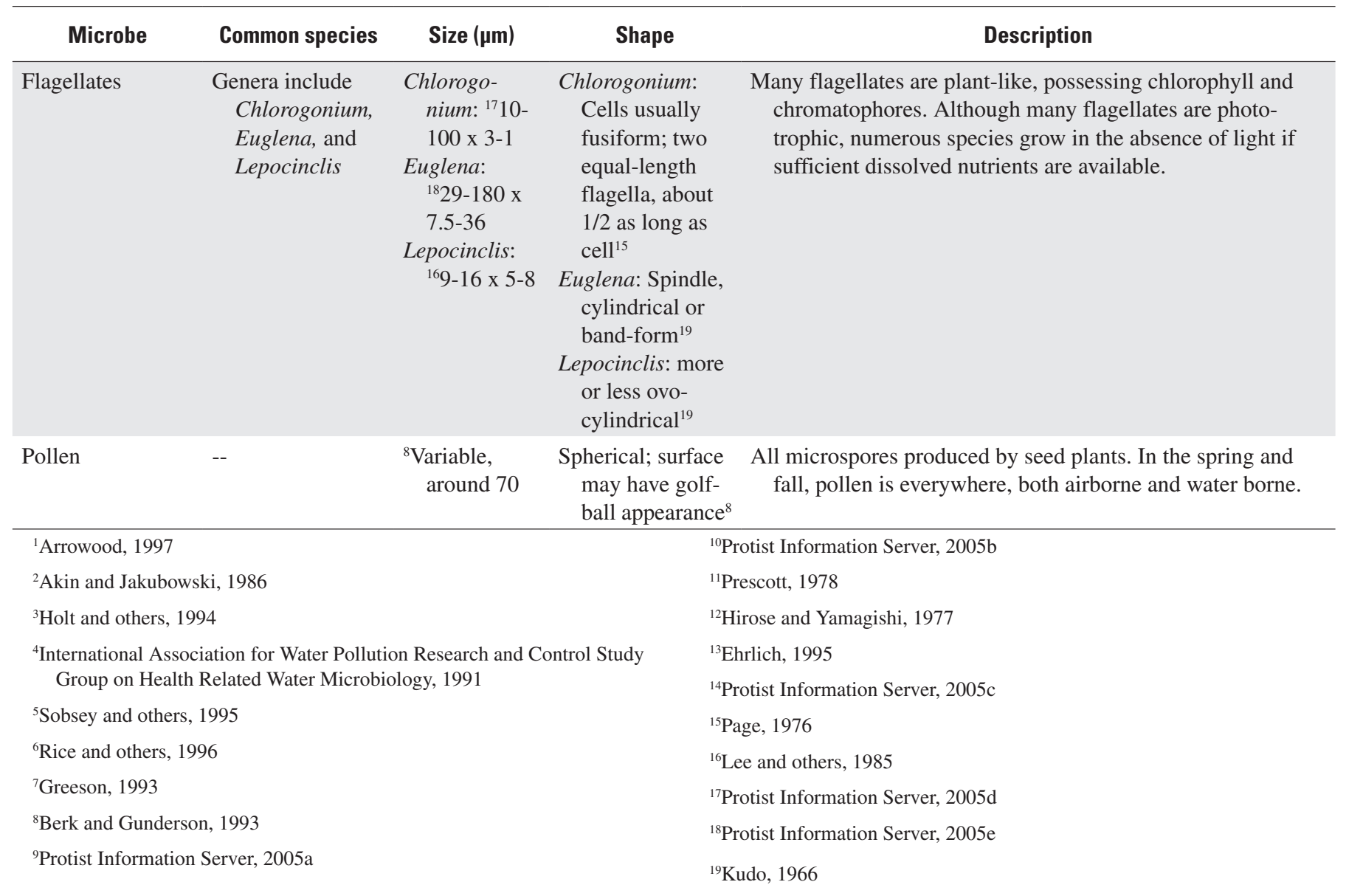

The alluvial sediments deposited by the Platte River, consisting mainly of sand and gravel and some silt and clay, increasingly have been developed for drinking-water supply by cities along the Platte River. At the same time, river and ground-water quality are being influenced by releases of wastewater and runoff from fields along the river. The municipal water supply from the well field along the river generally is affected by the quality of water from the local streams and the main channel (Verstraeten and others, 1999). The well field consists of 2 horizontal and 36 vertical wells completed in the alluvial sediments, generally at depths of less than 40 $\mathrm{m}$ (meters). Water obtained from the well field is used for a population of more than 230,000 people, which is growing at a rapid rate that may require development of additional large capacity wells at the well field.

\section{Methods}

This section of the report describes the sampling and analytical methods used in the study. The quality-assurance samples collected for this study are also described.

\section{Sampling Methods}

During this study, representative water samples were collected monthly or quarterly according to a pre-determined schedule from four sites: surface water from the Platte River near Ashland, Nebraska, ground water from well W90-1H, raw water, and finished water. Well $90-1 \mathrm{H}$ is a horizontal collector well that is located on an island in the middle of the Platte River. Raw water is influent to the drinking-water treatment plant that uses water from the site as source water. In general, the raw water is approximately 50 percent verticalwell water and 50 percent horizontal-well water. This ratio varies throughout the year based on management of the well field. Finished water is the effluent of the drinking-water treatment plant after treatment by rapid sand filtration, ozonation, and chloramines. Additional samples collected from a fifth site (well W49-9) were analyzed only for stable hydrogen and isotope ratios. All water samples were collected using approved sampling protocols (U.S. Geological Survey, 19972004). Because Kistemann and others (2002) suggested that substantial shares of the total microbial loads in watercourses result from rainfall and extreme events, samples also were collected during a spring-runoff event and two summer-runoff 
events. Other regularly scheduled samples also were collected during runoff events if the event occurred on the day scheduled for sampling. Boyer and Kuczynska (2003), however, reported that Cryptosporidium oocyst densities were not correlated to storm-dependent flow in an agriculturally influenced karst spring.

\section{Analytical Methods}

Water samples were analyzed in the field for $\mathrm{pH}$, temperature, specific conductance, dissolved oxygen (DO), and turbidity using USGS procedures for collecting field measurements (U.S. Geological Survey, 1997-2004). Dissolved organic carbon (DOC), microbial concentrations (Cryptosporidium, Giardia, male-specific and somatic coliphages, total coliform, E. coli, aerobic spores, enterococci, and MPA), laser particle counts, and stable hydrogen and oxygen isotope ratios were determined by analytical laboratory methods. DOC analysis was completed at the USGS National Water Quality Laboratory (NWQL) using the methods of Brenton and Arnett (1993). The NWQL is certified by the National Environmental Laboratory Accreditation Program, which is the only program that accredits environmental laboratories on a national basis for drinking-water analyses. Coliphage analysis was completed in the USGS Ohio Water Science Center Microbiology Laboratory. Other laboratory analyses described in this report were completed at other USGS or USEPA-approved laboratories. The USGS National Water Information System (NWIS) database permanently stores water-quality information collected by the USGS. However, some analytical data were not entered into the NWIS database, such as values for constituents that were obtained using non-approved methods (screening or research methods). These data were entered into a project water-quality database that was archived by the USGS Nebraska Water Science Center.

\section{Microbes}

Samples collected for this study were analyzed for microbes including Cryptosporidium, Giardia, male-specific $(\mathrm{F}+)$ and somatic coliphages, total coliform, E. coli, aerobic spores, and enterococci (table 1). MPA techniques were used to quantify concentrations of algae, diatoms, rotifers, amoeba, nematodes, flagellates, and pollen (table 1).

\section{Cryptosporidium and Giardia}

For analysis of Cryptosporidium and Giardia concentrations, USEPA method 1623 was utilized (U.S. Environmental Protection Agency, 2001a). An absolute porosity filter

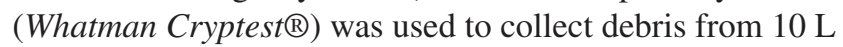
(liters) of water. If the water was too turbid to allow filtration of $10 \mathrm{~L}$, a lesser volume was filtered. The filter was eluted through backflushing and the debris was collected and centrifuged to concentrate it. The concentrate was subjected to immunomagnetic separation (IMS) that specifically retains the Cryptosporidium oocysts and Giardia cysts and allows the background debris to be removed. The IMS part of the sample was placed on a well slide and stained with fluorescein-tagged antibodies to Cryptosporidium and Giardia and a vital dye stain (DAPI) that specifically delineates the nuclei within the organisms. The slides were examined microscopically, and organisms that were identified as Cryptosporidium and Giardia were counted.

\section{Total Coliform and E. Coli}

Total coliform and E. coli concentrations were determined using the most-probable number (MPN) method from Colilert $^{\mathrm{TM}}$ at the Nebraska Health and Human Services Laboratory. Colilert ${ }^{\mathrm{TM}}$ is a commercially available liquid medium (Idexx Corporation, Westbrook, Maine) that allows the simultaneous detection of total coliforms and E. coli. The MPN method is facilitated by use of a specially designed disposable incubation tray called the Quantitray. To perform the analysis, two enzyme substrates are reacted in Colilert ${ }^{\mathrm{TM}}$ - $\mathrm{a}$ chromogen that reacts with the enzyme found in total coliforms (galactosidase), and a fluorogen that reacts with an enzyme found in E. coli (glucuronidase). After 24 hours of incubation at $35^{\circ} \mathrm{C}$ (degrees Celsius), a totalcoliform-positive reaction turns the medium yellow, while an E. coli-positive reaction causes the medium to fluoresce under a long-wave ultraviolet light (366 nanometers). A dilution step was added to the procedure on November 10, 2003, effectively raising the maximum detectable concentration of the method from $201 \mathrm{MPN} / 100 \mathrm{~mL}$ to 2,420 MPN/100 mL.

\section{Coliphages}

Male-specific $(\mathrm{F}+)$ and somatic coliphages in water were analyzed using the single agar layer (SAL) procedure (USEPA Method 1602; U.S. Environmental Protection Agency, 2001b). Antibiotic-resistant host-culture strains E. coli F-amp (resistant to streptomycin and ampicillin) and $E$. coli $\mathrm{CN}-13$ (resistant to nalidixic acid) were used as hosts for male-specific and somatic coliphages, respectively. A 100-mL (milliliter) sample was combined with magnesium chloride, log-phase host bacteria, and tryptic soy agar. The sample mixture was poured into plates and incubated overnight. If phage particles are present in the sample, they infect an E. coli cell and reproduce, causing death of the cell and cell lysis. This continues until a plaque is visible; a plaque is a circular clearing in the bacterial lawn. The plaques were counted and summed for all plates from a single sample and expressed as plaques per $100 \mathrm{~mL}$.

\section{Aerobic Spores}

Aerobic spores were analyzed in the laboratory of Dr. Gene Rice at the USEPA in Cincinnati, Ohio using the procedures of Rice and others (1996). During analysis, the samples were placed in a sterile flask, agitated, and heated to $80^{\circ} \mathrm{C}$. After 12 minutes at $80^{\circ} \mathrm{C}$, the flasks were cooled in an 
ice bath. Dilutions of the sample were filtered onto a $0.45-\mu \mathrm{m}$ porosity membrane filter. The membranes were then placed on nutrient agar medium containing the dye trypan blue, inverted, and incubated for $20-22$ hours at $35^{\circ} \mathrm{C}$. After incubation, all colonies on the plates were counted using a binocular dissecting microscope. All colonies in this procedure were considered to be derived from bacterial spores that were present in the sample and capable of surviving the heat treatment. Petri dishes with loose-fitting lids were used to facilitate growth of the strictly aerobic spore-formers during medium preparation.

\section{Enterococci}

Enterococci concentrations were determined using the MPN method from Enterolert ${ }^{\mathrm{TM}}$ at the USEPA labor oratory of Dr. Gene Rice in Cincinnati, Ohio. The MPN method is facilitated by use of the Quantitray. Enterolert ${ }^{\mathrm{TM}}$ detects enterococci such as E. faecium and E. faecalis in fresh and marine water because when enterococci use their $\beta$-glucosidase enzyme to metabolize the nutrient-indicator, 4-methyl-umbelliferyl B-D-glucoside, found in Enterolert ${ }^{\mathrm{TM}}$, the sample fluoresces. Enterococci are detected within 24 hours with a method detection limit of 1 colony forming unit (cfu) per $100 \mathrm{~mL}$ sample.

\section{Microscopic Particulate Analysis}

For MPAs, a yarn-wound depth filter was used to collect debris from either $100 \mathrm{~L}$ (surface water, ground water, and raw water) or 1,000 L (finished water). The particulates were eluted from the filter, and the washing was concentrated using centrifugation. In the case of raw water, centrifugation often was not necessary because enough particulates were present to examine the sample directly. Appropriate dilutions of the sample were made to provide adequate dispersion of particulates on a 100-microliter ( $\mu \mathrm{L})$ Palmer Maloney chamber. The particulates were counted and categorized by organism type (algae, diatom, nematode). Genus categorization was then attempted for algae and diatoms.

\section{Laser Particle Counts}

Laser particle counts (LPC) were determined by Analytical Services, Inc., in Williston, Vermont, using a Hiac/Royco Laser Particle Counter. For analysis, the machine pulls the water sample through a syringe, where a sensor uses "light scatter and light extinction technology" for determining particle size and concentration. The machine automatically calculates the averages of three sample runs for the same sample and reports this average as the result. The laser particle counter is calibrated every 12 months.

\section{Stable Hydrogen and Oxygen Isotope Ratios}

Samples from the Platte River and from two wells (W90-1H and W49-9) were analyzed for stable hydrogen and oxygen isotope ratios. Samples were collected monthly from well 49-9, which is approximately 300 meters from the Platte River at the study site.

Variations in stable isotope abundance ratios typically are small. Stable isotope ratios commonly are determined as relative difference in the ratio of the less abundant isotope (usually heavy) to the more abundant isotope (usually light) of the sample with respect to the reference. This difference is designated $\delta\left({ }^{i} \mathrm{E}\right)$ notation (pronounced delta) and it is defined according to the relation in equation 1 :

$$
\delta\left({ }^{i} \mathrm{E}\right)=\left[\frac{n_{\mathrm{X}}\left({ }^{i} \mathrm{E}\right) / n_{\mathrm{X}}\left({ }^{j} \mathrm{E}\right)}{n_{\text {ref }}\left({ }^{i} \mathrm{E}\right) / n_{\text {ref }}\left({ }^{j} \mathrm{E}\right)}-1\right]
$$

where $\delta\left({ }^{i} \mathrm{E}\right)$ refers to the delta value of isotope number $i$ of element $\mathrm{E}$ of sample $\mathrm{X}$ relative to the reference (ref), and $n_{\mathrm{X}}\left({ }^{i} \mathrm{E}\right) / n_{\mathrm{X}}\left({ }^{j} \mathrm{E}\right)$ and $n_{\text {ref }}\left({ }^{i} \mathrm{E}\right) / n_{\text {ref }}\left({ }^{j} \mathrm{E}\right)$ are the ratios of the isotope amounts in unknown $\mathrm{X}$ and a reference (ref). A positive $\delta\left({ }^{i} \mathrm{E}\right)$ value indicates that the unknown is more enriched in the heavy isotope than the reference. A negative $\delta\left({ }^{i} \mathrm{E}\right)$ value indicates that the unknown is depleted in the heavy isotope relative to the reference. The $\delta\left({ }^{i} \mathrm{E}\right)$ is commonly shortened to $\delta^{i} \mathrm{E}$ and has been reported in parts per hundred (\% or percent), parts per thousand (\%o or per mill), and parts per ten thousand. In this report, $\delta\left({ }^{i} \mathrm{E}\right)$ values are given in \%o.

For stable hydrogen isotope ratios

$$
\delta^{2} \mathrm{H}=\left[\frac{n_{\mathrm{X}}\left({ }^{2} \mathrm{H}\right) / n_{\mathrm{X}}\left({ }^{1} \mathrm{H}\right)}{n_{\text {VSMOW }}\left({ }^{2} \mathrm{H}\right) / n_{\text {VSMOW }}\left({ }^{1} \mathrm{H}\right)}-1\right]
$$

where the isotope ratios are expressed relative to Vienna Standard Mean Ocean Water (VSMOW) reference water and they are normalized such that $\delta^{2} \mathrm{H}$ of Standard Light Antarctic Precipitation (SLAP) reference water is $-428 \%$ (Coplen, 1996). Hydrogen isotope ratios were determined by $\mathrm{H}_{2}-\mathrm{H}_{2} \mathrm{O}$ equilibration and analysis by isotope ratio mass spectrometry (Coplen and others, 1991). About 25 percent of analyses each day were reference samples and samples were analyzed in replicate. The 2-sigma uncertainty of hydrogen isotopic results is $2 \%$. This means that if a sample was resubmitted for analysis at a later date, there is a 95-percent probability that the hydrogen isotopic result reported will be within $2 \%$ of the result originally reported.

For oxygen isotope ratios

$$
\delta^{18} \mathrm{O}=\left[\frac{n_{\mathrm{X}}\left({ }^{18} \mathrm{O}\right) / n_{\mathrm{X}}\left({ }^{16} \mathrm{O}\right)}{n_{\text {VSMOW }}\left({ }^{18} \mathrm{HO}\right) / n_{\text {VSMOW }}\left({ }^{16} \mathrm{O}\right)}-1\right]
$$

where the isotope ratios are expressed relative to VSMOW reference water, and they are normalized such that ${ }^{18} \mathrm{O}$ of SLAP reference water is $-55.5 \%$ (Coplen, 1996). Oxygen isotope ratios are determined by the $\mathrm{CO}_{2}-\mathrm{H}_{2} \mathrm{O}$ equilibration method of Epstein and Mayeda (1953). About 20 percent of analyses each day were isotopic reference water, and about 35 percent of samples were analyzed in replicate. The 2-sigma 
uncertainty of oxygen isotopic results is $0.2 \%$. This means that if a sample is resubmitted for analysis at a later date, there is a 95-percent probability that the isotopic result reported will be within $0.2 \%$ of the result originally reported.

\section{Quality Assurance/Quality Control}

Various quality-assurance (QA) samples were collected for this study. Duplicate samples consist of splits from the same sample aliquot that are collected in such a manner that the samples are assumed to be essentially identical in composition. Duplicate samples for Cryptosporidium and Giardia analysis were collected from the Platte River on March 17, 2003, and from well W90-1H on June 30, 2003. Duplicate samples for somatic and male-specific coliphages were collected from the Platte River on October 20, 2003; from well W90-1H on April 15, 2003, and March 16, 2004; from the raw water on May 13, 2003, and January 13, 2004; and from the finished water on September 16, 2003. Duplicate MPA samples were collected from well W90-1H on March 18, 2003, and from the raw water on May 13, 2003. Duplicate LPC samples were collected from the Platte River on December 9, 2002, and November 15, 2003; from well W90-1H on December 16, 2003; from the raw water on January 21, 2003, and June 30, 2003; and from the finished water on May 27, 2003, and January 13, 2004.

Equipment blanks, which are samples of ultrapure deionized water that have been processed with the same sample collection equipment used to collect the surface-water environmental samples, also were collected and analyzed for various microbes. An equipment blank was collected on April 1, 2003, and analyzed for Cryptosporidium and Giardia. A second equipment blank was also collected on June 18, 2003, and analyzed for male-specific and somatic coliphages. A third equipment-blank for MPA was collected on January 21, 2003. Additional quality-assurance and quality-control (QC) measures inherent to the laboratory methods and consistent with each laboratory QA plan also were taken. In addition, a three-tiered approach of QC divided into method performance (instrument and method), data review and blind sample programs, and performance evaluation studies were applied at the NWQL (Pirkey and Glodt, 1998).

\section{Streamflow and Well Pumpage}

Streamflow during the period of study of riverbank filtration at the established well field was compared to the natural variability in the hydrologic system through use of long-term streamflow information. Historical median streamflow data used for comparisons are available at http://nwis.waterdata. usgs.gov/ne/nwis/sw for the Platte River near Ashland (station 0681000) for water years 1929 to 2004. Daily mean streamflow during the study period was compared to the historical mean daily streamflow in the Platte River (fig. 2). Flow conditions were tracked for several days around each sample date at the Platte River sampling site (fig. 3). Streamflow conditions denoted as being impacted by "Ice" in figure 3 will not reflect accurate flow conditions because of changes in the stage-discharge relation caused by ice in the channel. In addition, well field management caused varied pumping rates during different times of the year in the collector well W90-1H (fig. 4), total flow into the treatment plant, and total well field pumpage during the study period.

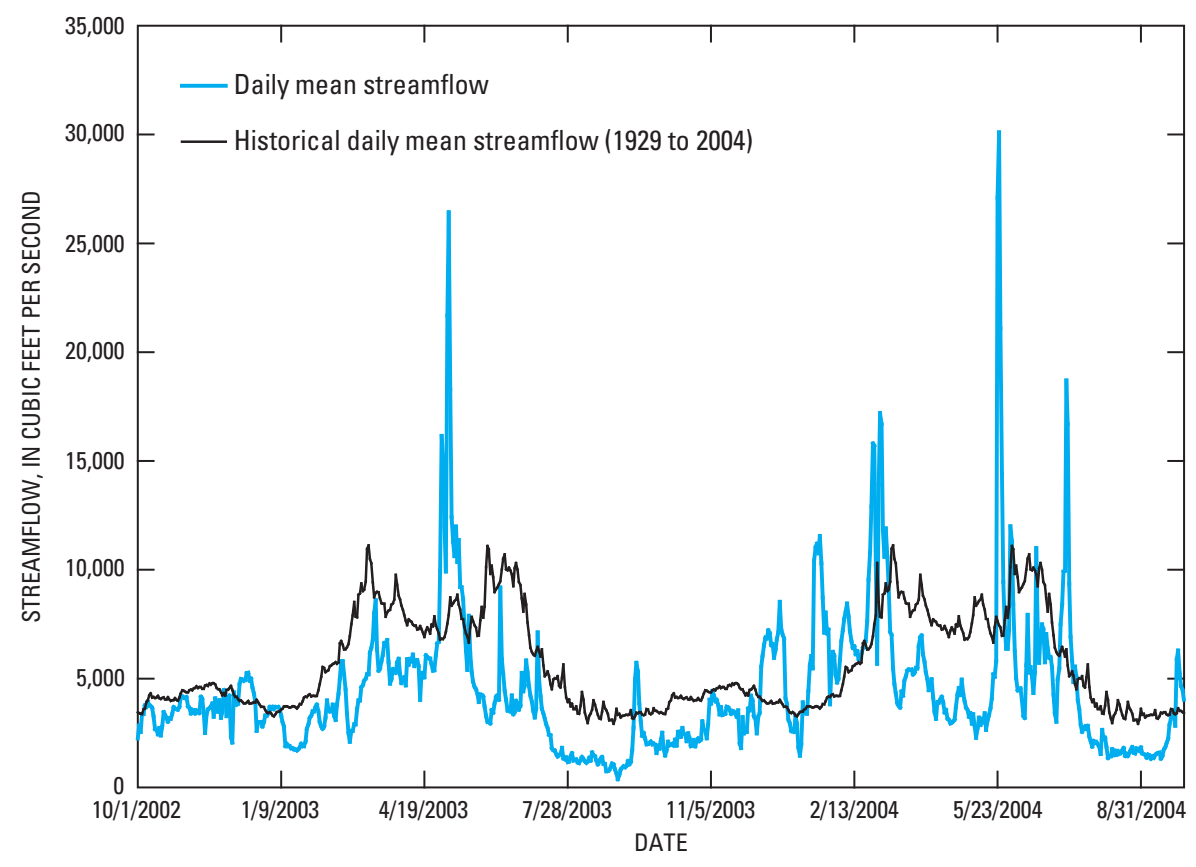

Figure 2. Comparison of average daily streamflow and historical mean daily streamflow at the Platte River near Ashland gaging station (06801000). 

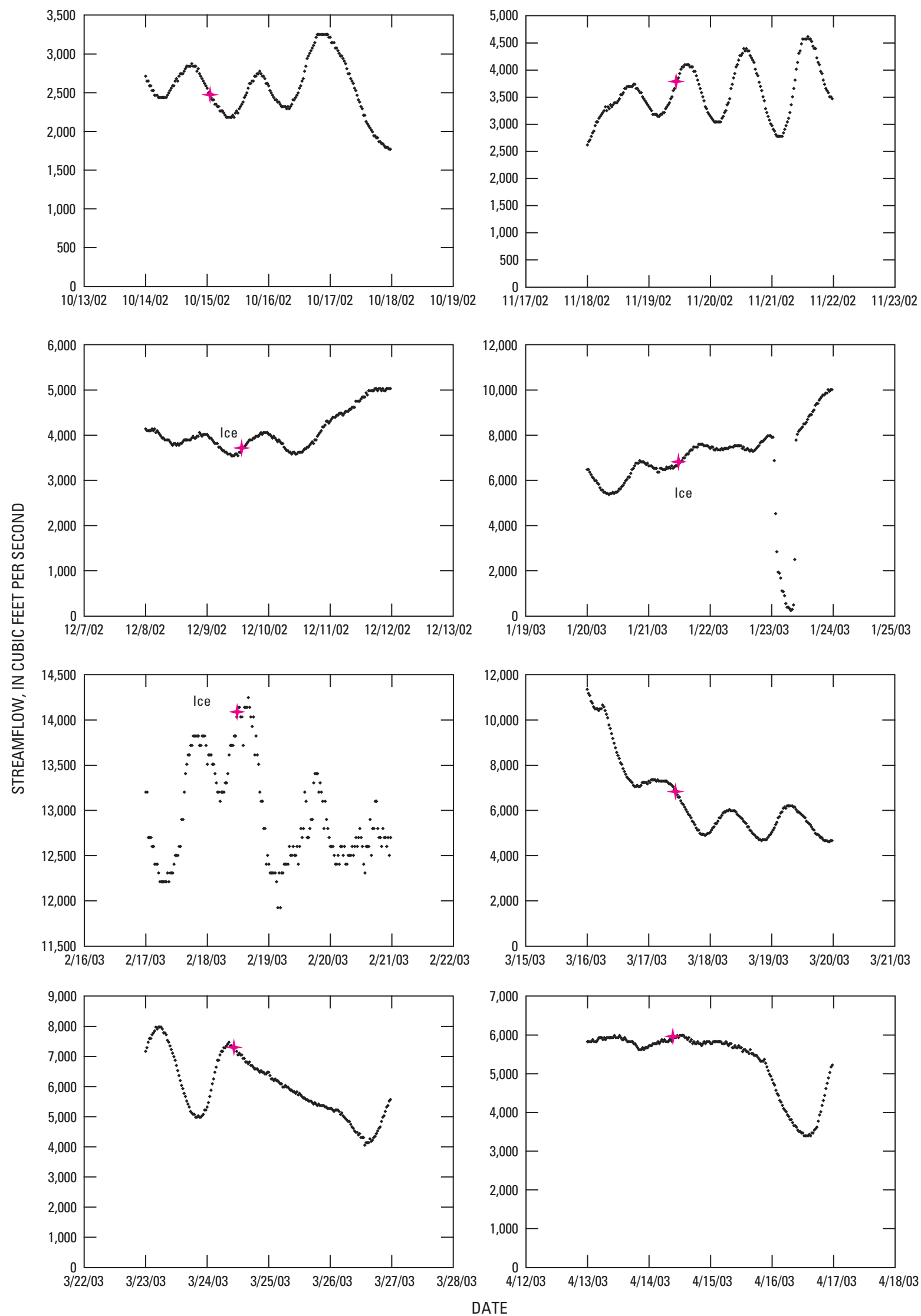

Figure 3. Flow conditions during sampling in the Platte River near Ashland between October 2002 and September 2004. Sample collection times are represented by stars. 

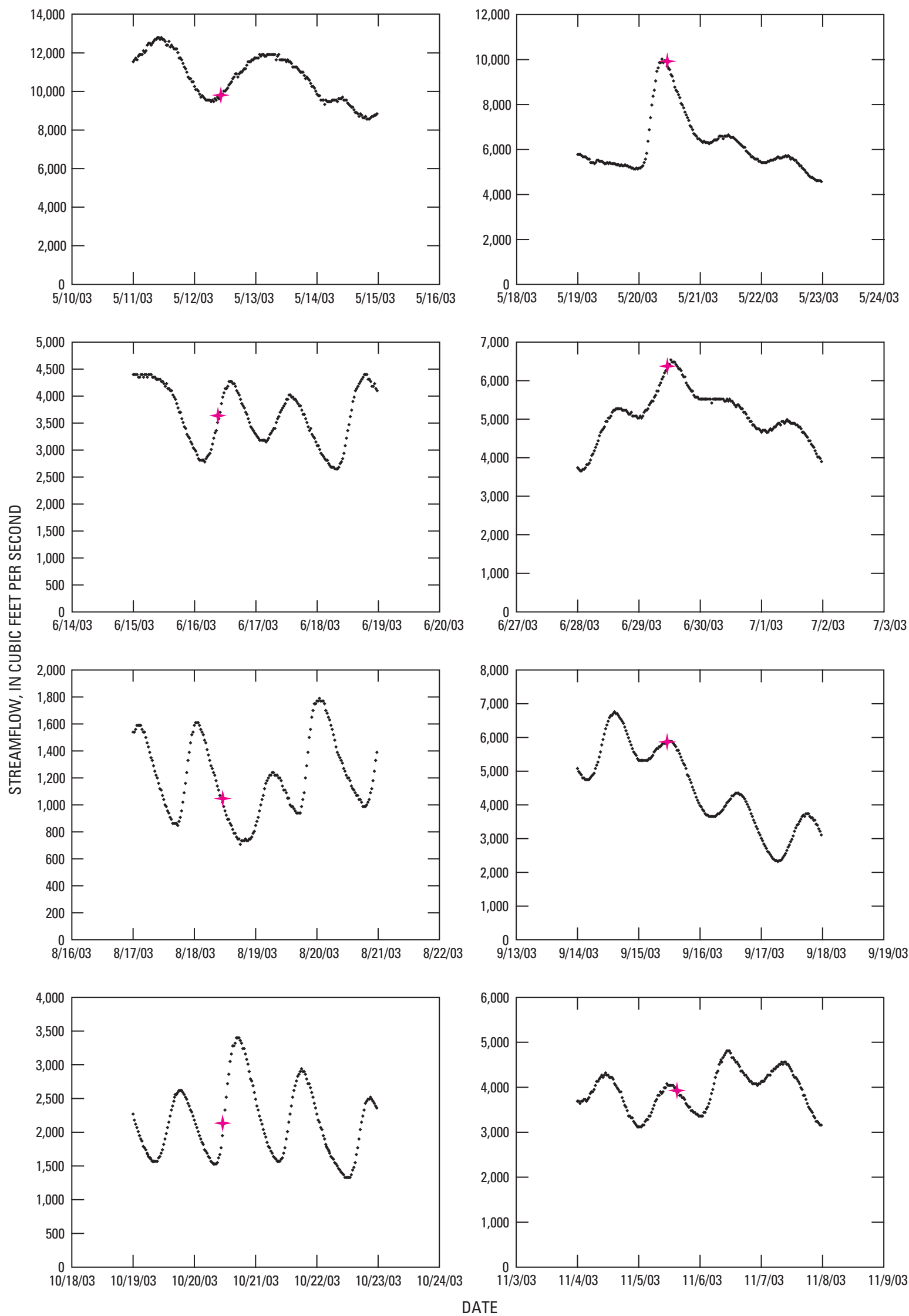

Figure 3. Flow conditions during sampling in the Platte River near Ashland between October 2002 and September 2004. Sample collection times are represented by stars. - Continued 

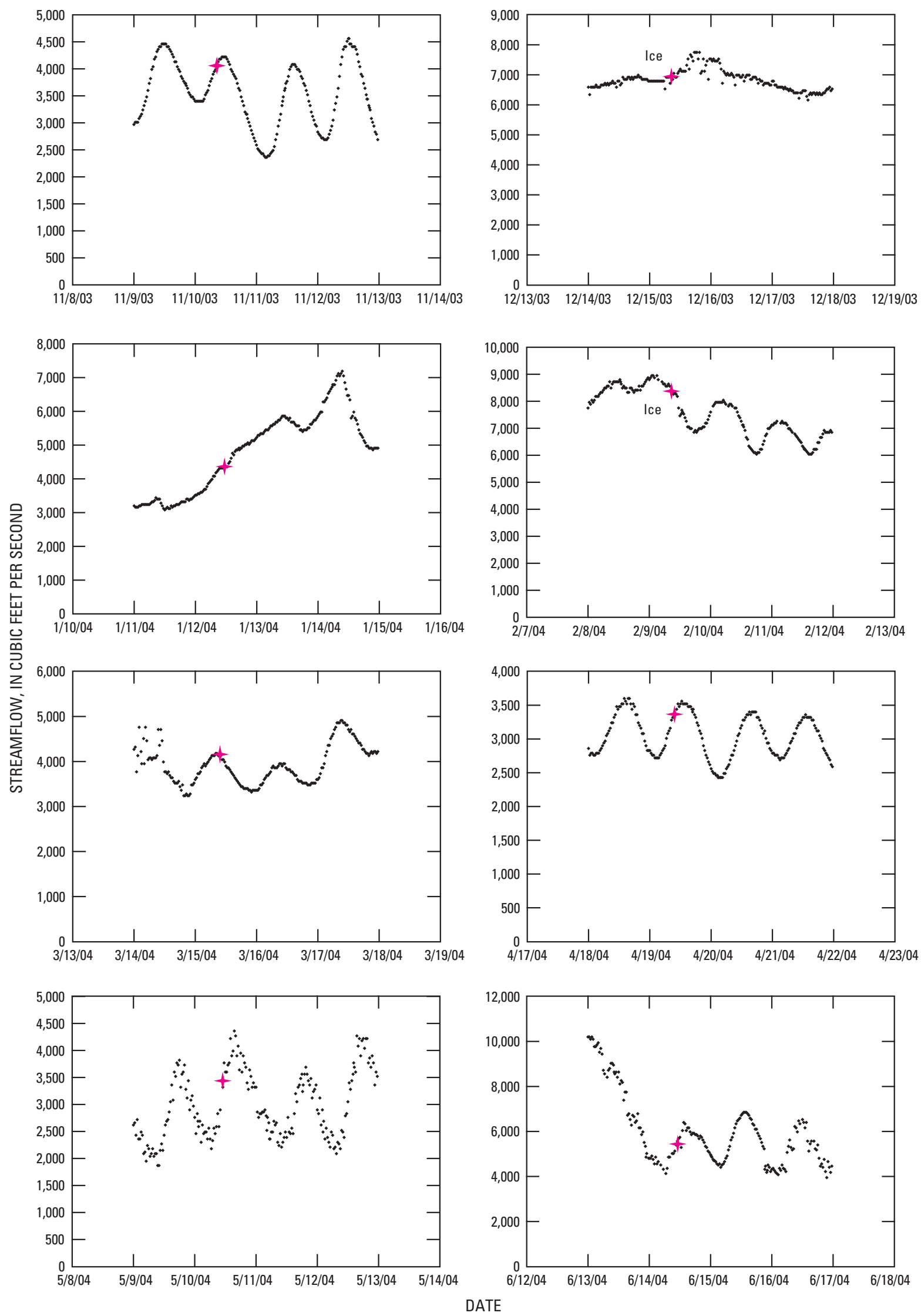

Figure 3. Flow conditions during sampling in the Platte River near Ashland between October 2002 and September 2004. Sample collection times are represented by stars.-Continued 

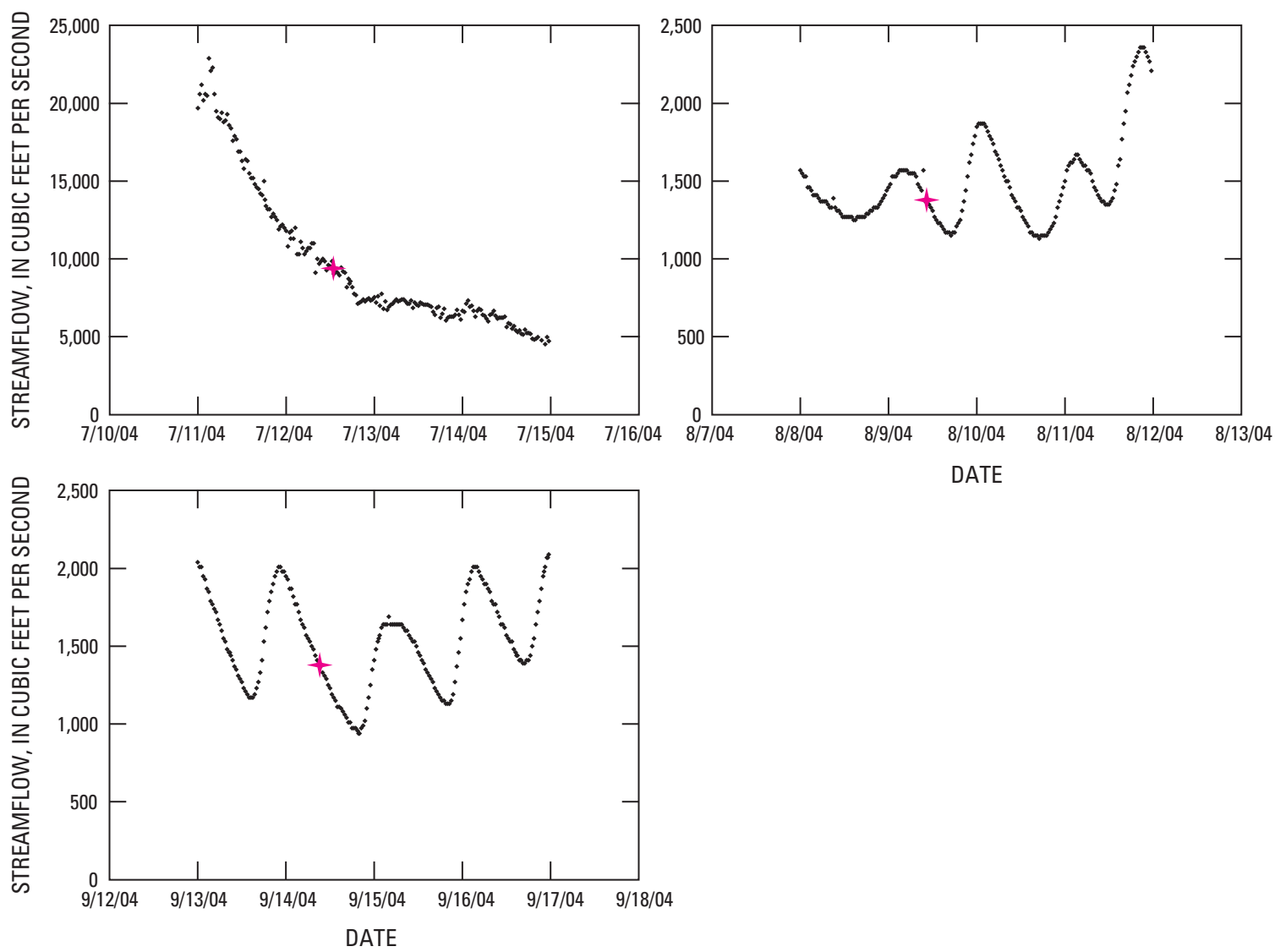

Figure 3. Flow conditions during sampling in the Platte River near Ashland between October 2002 and September 2004. Sample collection times are represented by stars.-Continued

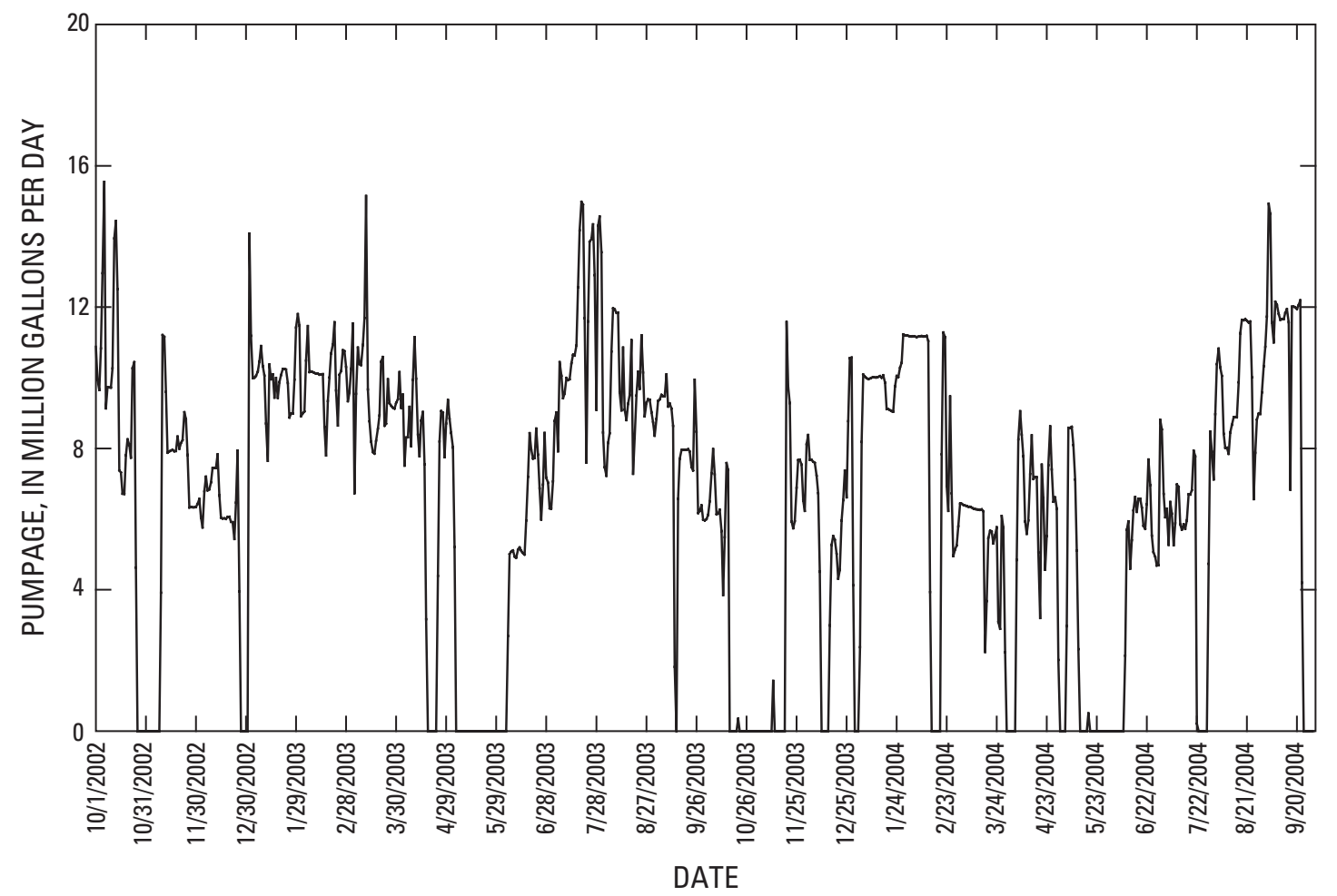

Figure 4. Pumpage in collector well W90-1H during the period of the study. 


\section{Field Water-Quality Properties}

Field water-quality properties were measured at each site (fig. 5; table 2). Water temperature in the Platte River varied seasonally and generally mirrored the air temperature, with a measured minimum temperature of $0^{\circ} \mathrm{C}$ and maximum temperature of $29.8^{\circ} \mathrm{C}$. The temperature of the ground water from well W90-1H generally mirrored the Platte River temperature with a lag of 1 to 2 months. Measured water temperature in well W90-1 $\mathrm{H}$ varied from 4.5 to $20.8^{\circ} \mathrm{C}$. Water temperature at the drinking-water sampling sites (raw water and finished water) showed less variability than in the ground-water well, with summer temperatures similar to air temperatures and somewhat stable temperatures (around 12 to $13^{\circ} \mathrm{C}$ ) in the winter. This is a result of the indoor location of these two sampling sites.

The $\mathrm{pH}$ of Platte River samples varied from 7.55 to 8.97 through the sample period, with no apparent seasonal trend. Samples collected from well W90-1H had less variability in measured $\mathrm{pH}$ values than the Platte River, ranging from 7.26 to 8.00 during the study period. In general, the $\mathrm{pH}$ of the rawwater and finished-water samples was similar to the $\mathrm{pH}$ of the ground water samples from well W90-1H.

Specific conductance of samples collected from the Platte River varied from 310 to 567 microsiemens per centimeter $(\mu \mathrm{S} / \mathrm{cm})$ during the study period. The specific conductance of samples from well W90-1H, raw water, and finished water were similar and showed less variability than the Platte River samples. One outlier measurement occurred on April 1, 2004, when specific conductance of the finished water sample measured $744 \mu \mathrm{S} / \mathrm{cm}$.

Dissolved-oxygen (DO) concentrations in samples from the Platte River ranged from 4.35 to $15.37 \mathrm{mg} / \mathrm{L}$. The lower concentrations generally occurred in the summer months and the higher concentrations during the winter months. Measured DO concentrations in the ground-water samples from well W90-1H showed a trend similar to the Platte River with a lag time of 1 to 2 months. The DO measurements in well W90-1H ranged from 0.12 to $8.74 \mathrm{mg} / \mathrm{L}$. Compared to the $\mathrm{W} 90-1 \mathrm{H}$ samples, raw-water samples had higher DO concentrations in the summer months and lower DO concentrations during the winter months. In general, DO concentrations in the finished water samples were higher than in the raw water samples due to aeration during the treatment process.

Turbidity in Platte River samples ranged from 6.46 to $1,536 \mathrm{NTU}$ (nephelometric turbidity units) during the study period (fig. 6; table 2). Turbidity in samples from well $\mathrm{W} 90-1 \mathrm{H}$, raw water, and finished water were similar and ranged from 2 to 4 magnitudes less than the turbidity of Platte River samples collected at similar sample times.

Concentrations of DOC in samples from the Platte River ranged from 1.9 to $6.0 \mathrm{mg} / \mathrm{L}$ during the study period, with higher concentrations generally measured in the summer months (fig. 7; table 2). Samples from well W90-1H contained more consistent concentrations of DOC throughout the year than samples from the Platte River, with concentrations in well W90-1H ranging from $1.8 \mathrm{mg} / \mathrm{L}$ to $3.5 \mathrm{mg} / \mathrm{L}$. In general, DOC concentrations in W90-1H samples were similar to Platte River samples during the winter months and lower during the summer months. Blind samples also were analyzed by the NWQL as part of the Organic Blind Sample Project to assess operational performance of the dissolved organic methods (table 3) (U.S. Geological Survey, 2004).

\section{Microbial Concentrations}

Results from microbial analysis are presented in this section of the report. Results of QA/QC samples that were analyzed for microbes also are presented.

\section{Cryptosporidium and Giardia}

Samples from all four sites were analyzed for Cryptosporidium and Giardia concentrations (tables 4 and 5). Environmental and duplicate samples from the Platte River on March 17, 2003, and from well W90-1H on June 30, 2002, respectively, had no detectable Cryptosporidium or Giardia. In addition, an equipment blank collected on April 1, 2003, using surface-water collection equipment had no detectable Cryptosporidium or Giardia (table 5). Mean recovery of Cryptosporidium was 42 percent and mean recovery of Giardia was 39 percent, with a coefficient of variation (CV) of 36.5 percent for Cryptosporidium and a CV of 38.7 percent for Giardia for all samples collected during this study (table 6). All of these samples were analyzed using the Whatman Cryptest ${ }^{\circledR}$ filter. These findings are less than the mean and $\mathrm{CV}$ of recovery for Cryptosporidium (mean $=54, \mathrm{CV}=33.1$ ) and greater than the mean and $\mathrm{CV}$ of recovery for Giardia (mean=25, CV=100.8) in natural waters reported by DiGiorgio and others (2002) using the Gelman Envirocheck ${ }^{\circledR}$ highvolume filter.

Cryptosporidia were detected in 48 percent (13 of 27) of Platte River samples collected during the study, and Giardia were detected in 44 percent (12 of 27) of Platte River samples collected during the study. Both microbes, however, were not always detected in the same sample. In general, Cryptosporidium concentrations were greater and more variable than Giardia concentrations. Cryptosporidia were detected in every Platte River sample between November 5, 2003 and July 12, 2004 (9 of 13 detections), whereas Giardia detections generally were more scattered throughout the sampling period. Neither Cryptosporidium nor Giardia was detected in any samples from well $\mathrm{W} 90-1 \mathrm{H}$, the raw water, or the finished water. 

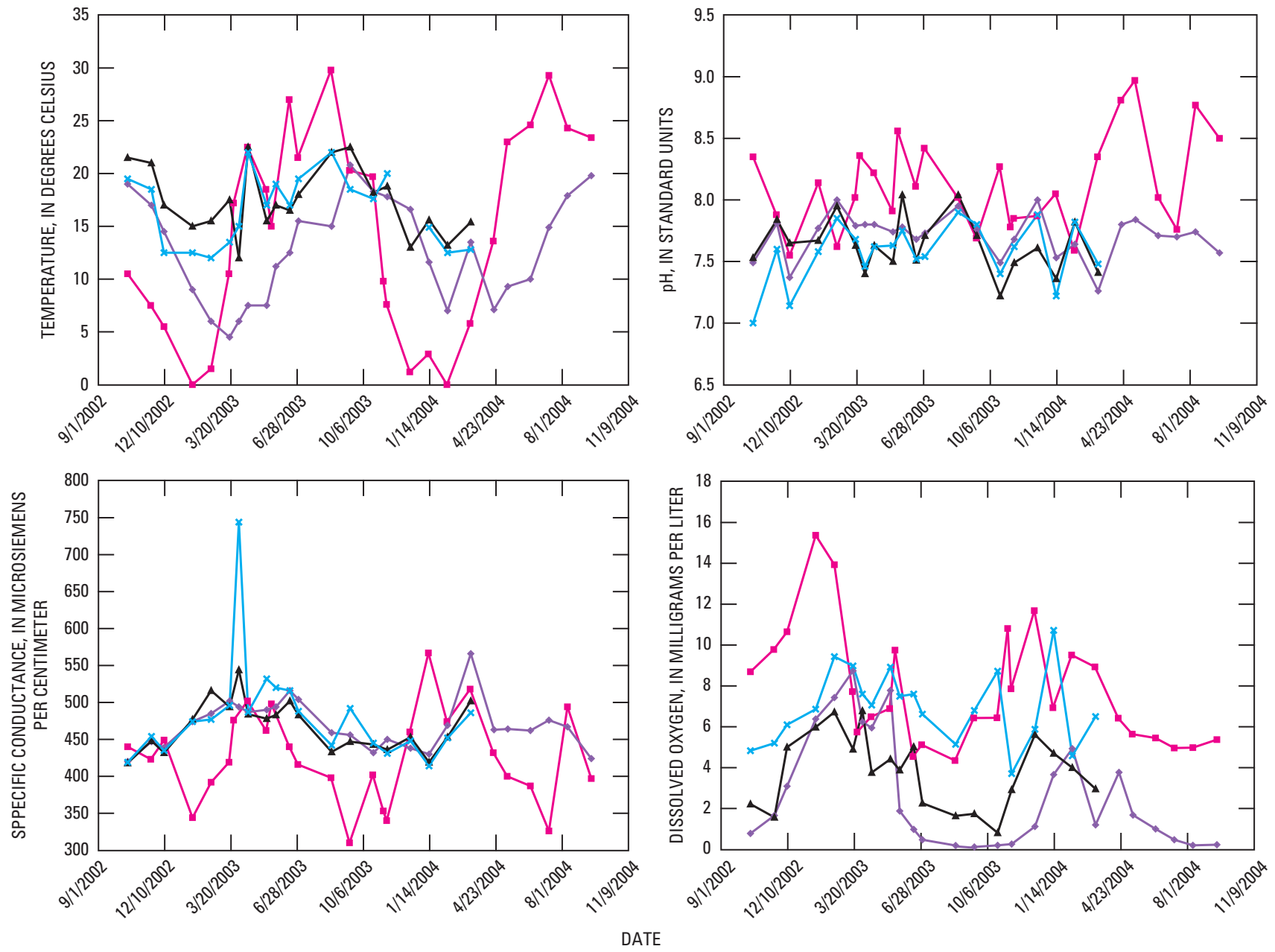

EXPLANATION

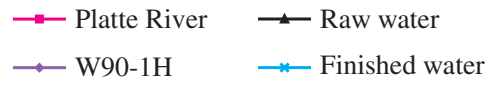

Figure 5. Field water-quality properties at selected sites during the riverbank filtration study, Platte River, Nebraska. 


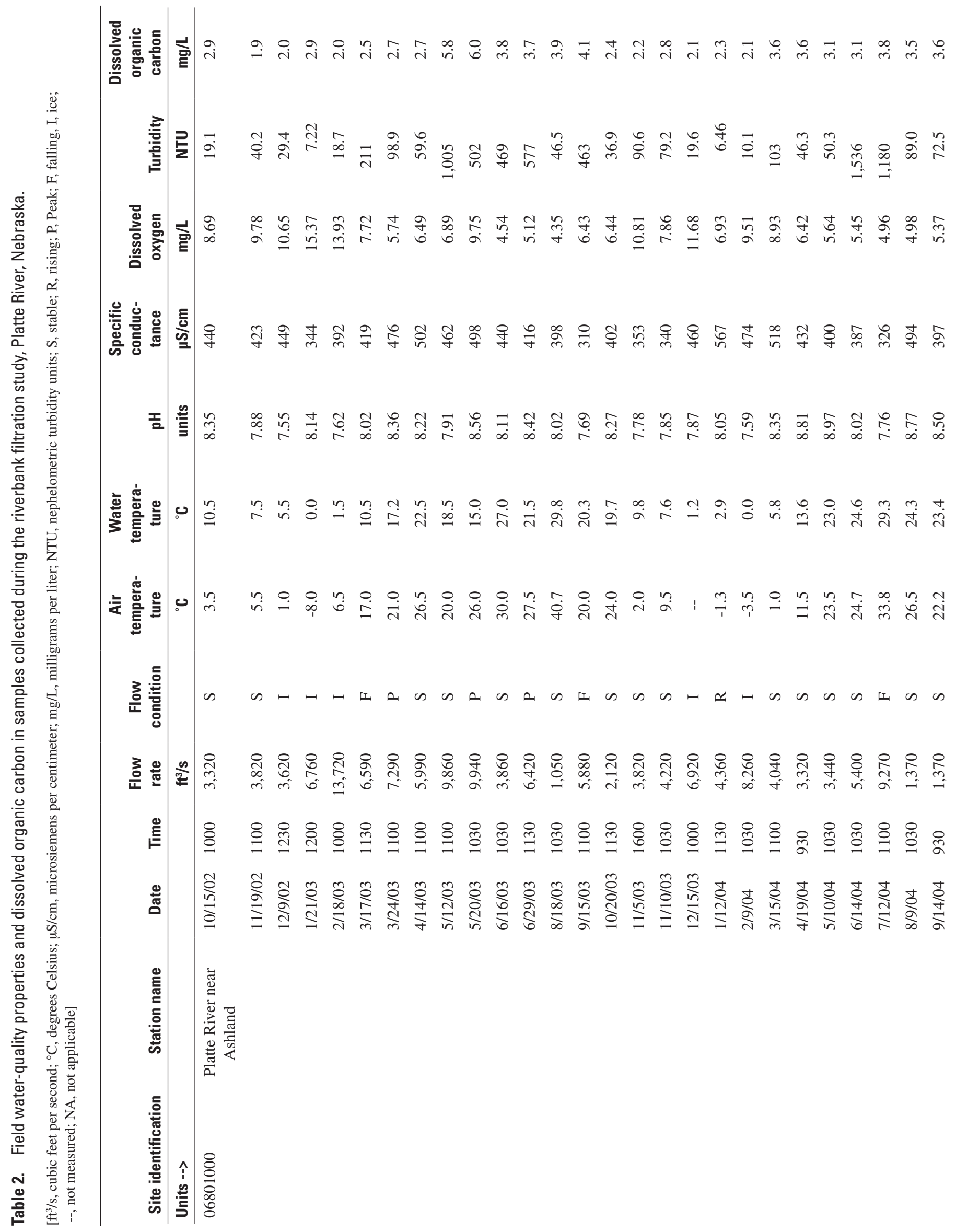




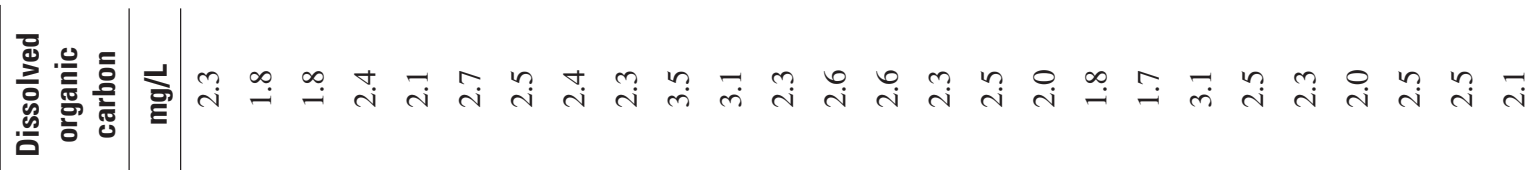




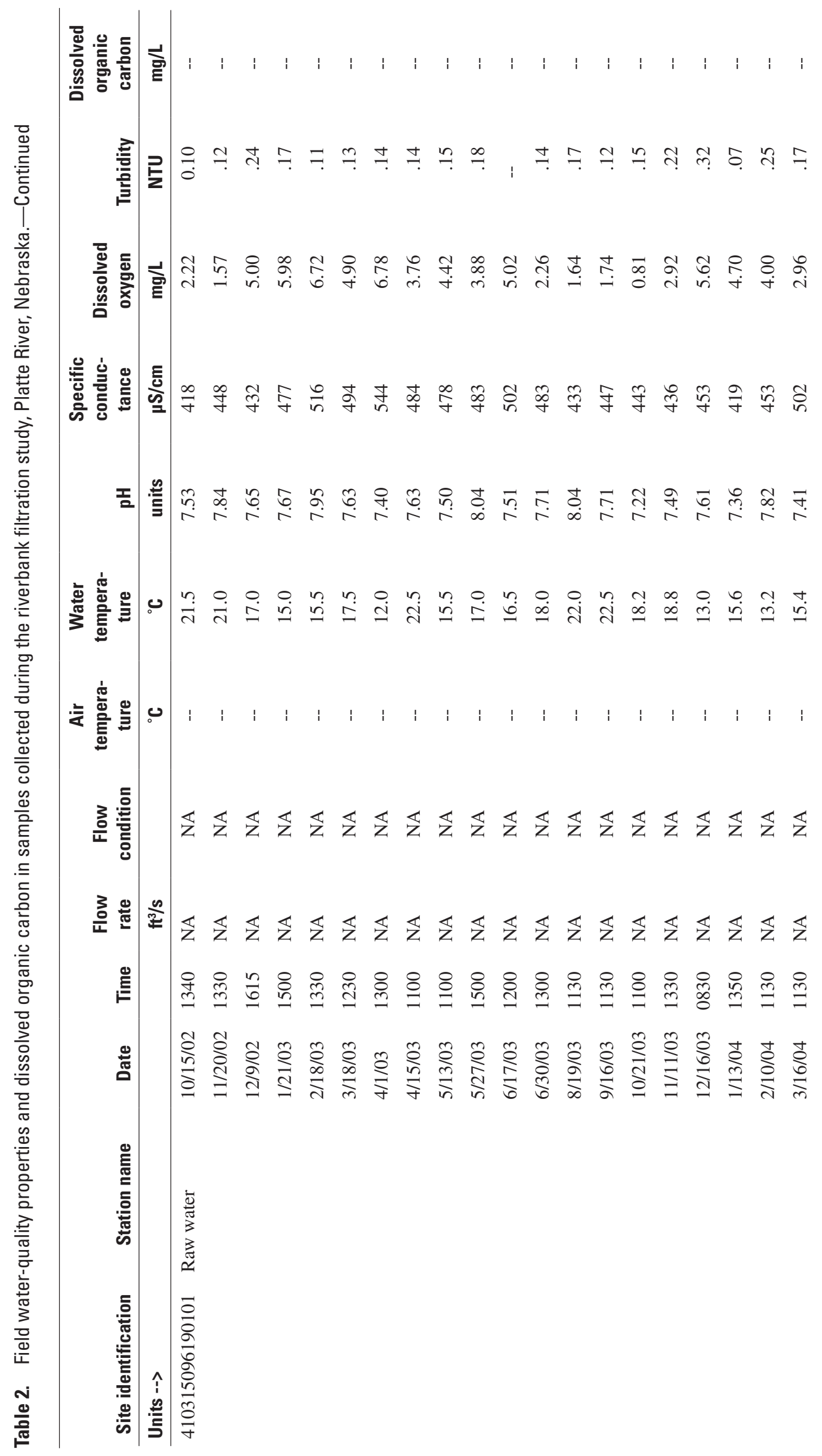




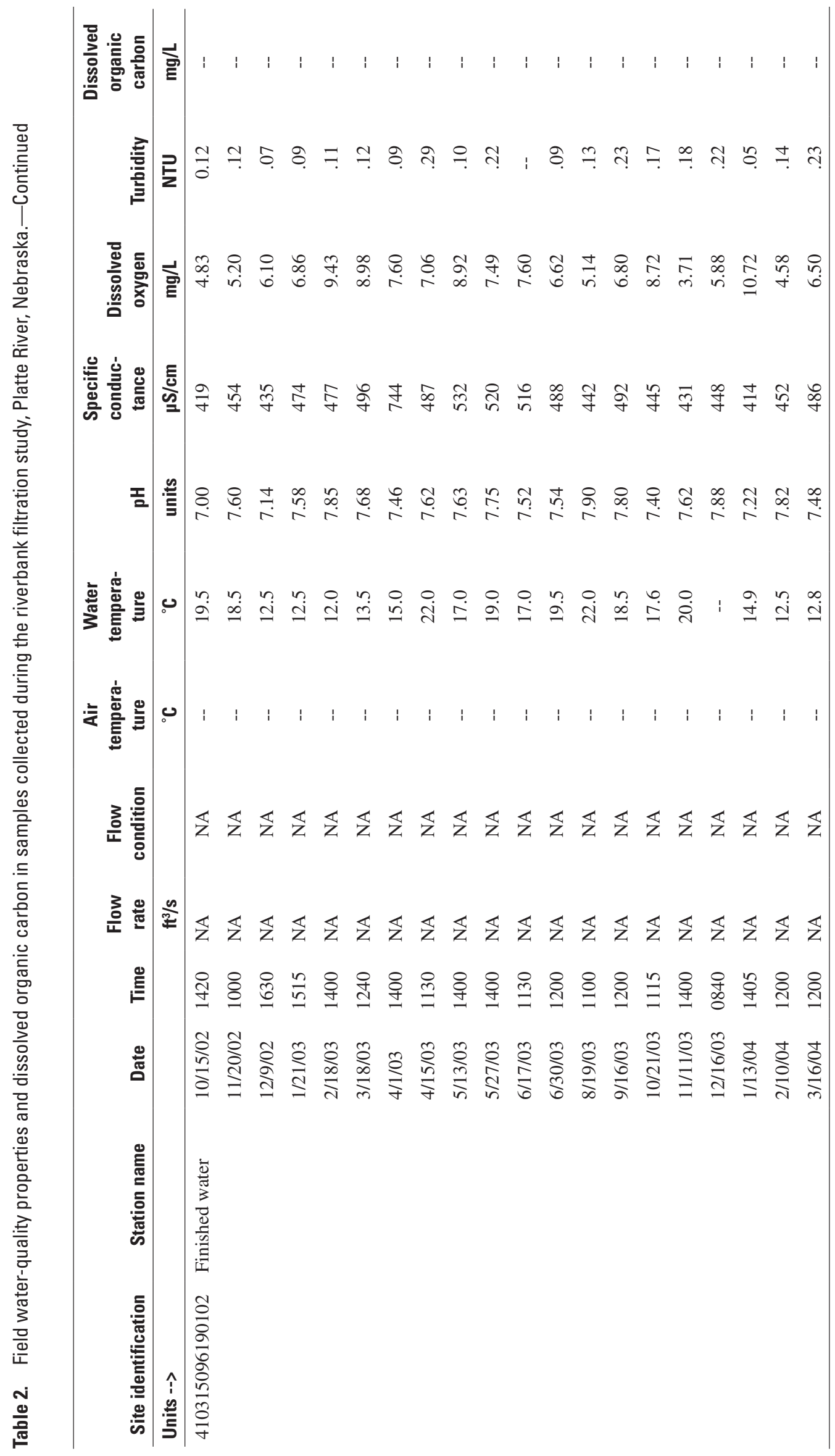


Table 3. Percentage recovery of dissolved organic carbon blind samples analyzed as part of the Organic Blind Sample Project by the National Water Quality Laboratory from February 23, 1999, to September 25, 2003. (Data from U.S. Geological Survey, 2004).

[mg/L, milligrams per liter]

\begin{tabular}{lcccc}
\hline Range, in mg/L & $\begin{array}{c}\text { Number } \\
\text { of } \\
\text { samples }\end{array}$ & $\begin{array}{c}\text { Median } \\
\text { (percent) }\end{array}$ & $\begin{array}{c}\text { Mean } \\
\text { (percent) }\end{array}$ & $\begin{array}{c}\text { Standard } \\
\text { deviation } \\
\text { (percent) }\end{array}$ \\
\hline $0.600-1.000$ & 10 & 113 & 119 & 16.8 \\
$1.000-15.00$ & 11 & 99.8 & 100 & 5.5 \\
$15.00-20.00$ & 4 & 110 & 114 & 20.1 \\
\hline
\end{tabular}

\section{Total Coliform and E. coli}

Samples from all four sites were analyzed for total coliform and E. coli concentrations (tables 4 and 7). Total coliforms were detected in all samples collected from the Platte River, in 30 percent ( 7 of 23) of the samples collected from well W90-1H, and in 16 percent (3 of 19) of the raw water samples. Total coliforms were not detected in any of the finished water samples. E. coli were detected in 88 percent $(22$ of 25) of the samples collected from the Platte River and in 9 percent (2 of 23) of the samples collected from well W901H. E. coli were not detected in any of the raw or finished water samples. Reported concentrations of total coliforms and $E$. coli in many samples from the Platte River and of total coliforms in samples from well W90-1H were greater than the maximum amount measured by the analytical method used, so summary statistics could not be calculated for these samples (table 4).

\section{Coliphages}

Samples from all four sites were analyzed for male-specific and somatic coliphage concentrations (tables 4 and 7). Male-specific coliphages were not detected in any samples on the dates that duplicate samples were collected, whereas two of six duplicate samples contained detectable levels of somatic coliphages. The environmental and duplicate samples collected from the Platte River on October 20, 2003, contained identical concentrations of somatic coliphages. Concentrations measured in the environmental and duplicate samples collected from well W90-1H on March 16, 2004, measured concentrations differing by $7 \mathrm{pfu}$ (44 percent).

In the Platte River, somatic coliphages were detected more often and generally in higher levels than male-specific coliphages. Somatic coliphages were detected in 23 percent (6 of 26) of samples from well W90-1H at concentrations less than in the Platte River sampled at approximately the same time. Somatic coliphages were detected in only a few samples at levels near the method detection limit (MDL) in the raw water and the finished water. Male-specific coliphages also were detected in only a few samples at levels near the MDL in well W90-1H, the raw water, and the finished water.

\section{Aerobic Spores}

Samples from all four sites were analyzed for aerobic spore concentrations (tables 4 and 7). Aerobic spores were detected in all samples collected from the Platte River and well W90-1H during this study. The mean concentration of aerobic spores in samples from the Platte River was 2.7 magnitudes greater than the mean concentration in samples from well W90-1H. Aerobic spores were detected in 18 of 19 raw water samples (95 percent) and 4 of 19 finished water samples (21 percent). The mean aerobic spore concentration in samples from well W90-1H was 0.3 magnitudes greater than the mean aerobic spore concentration in samples of the raw water. The mean aerobic spore concentration in raw water samples was 1.5 magnitudes greater than the mean aerobic spore concentration in the finished water samples.

\section{Enterococci}

Samples from all four sites were analyzed for enterococci concentrations (tables 4 and 7). Enterococci were detected in all samples from the Platte River. Only one sample from well W90-1H and one sample from the raw water contained detectable concentrations of enterococci, although these samples were not collected at the same time. Enterococci were not detected in any samples from the finished water.

\section{Microscopic Particulate Analysis}

MPAs were completed on samples from all four sites (tables 8 and 9). Of the classified non-diatomaceous algae analyzed in samples from the Platte River, Scendesmus was detected most often (14 of 15 samples). Unclassified algae were detected in all samples collected from the Platte River. Scendesmus also was the most detected classified algae in samples from well W90-1H (4 of 14 samples). All non-diatomaceous algae were detected less frequently and at lower mean concentrations in samples from well W90-1H than in samples from the Platte River except for Phacus, which was detected in 2 of 14 samples from the well, but not in any of the 15 samples from the Platte River. However, the MDLs for the samples from the Platte River were, on average, 5.8 magnitudes higher than the MDL (table 9). Scendesmus ( 2 of 7 samples) and Pediastrum (1 of 7 samples) were the only classified non-diatomaceous algae detected in raw water samples. Unclassified algae were detected in 3 of 7 raw water samples. Non-diatomaceous algae were not detected in 4 samples from the finished water, except for 1 sample, which contained unclassified algae. 


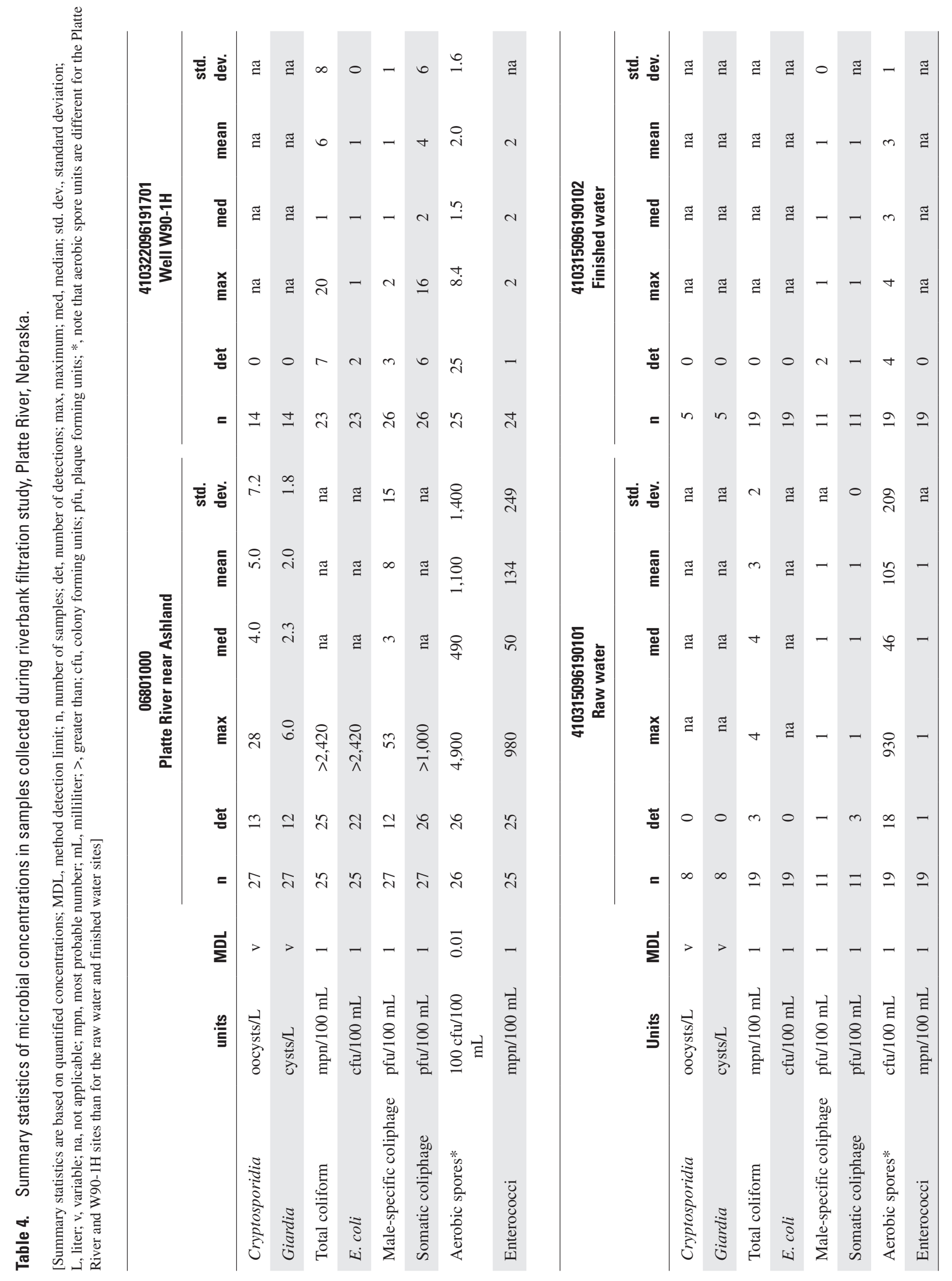


The most frequently detected classified diatom in samples from the Platte River was Navicula (9 of 15 samples). The highest mean concentration of classified diatoms in samples from the Platte River was Asterionella, although concentrations of this diatom also had the highest standard deviation. Unclassified diatoms were detected in 60 percent of the samples (9 of 15) from the Platte River. At least one type of diatom was detected in all samples from the Platte River. Detectable concentrations of classified diatoms were not present in any samples from well W90-1H, except for Tabellaria, which was detected in one sample. Unclassified diatoms were detected in 2 of 14 samples from well W90-1H. Classified diatoms were not detected in raw water samples, while unclassified diatoms were detected in 1 of 7 raw water samples. Diatoms were not detected in any of the four finished water samples.

Five other microscopic particles were quantified by the MPA (rotifers, amoebae, nematodes, flagellates, and pollen). The only type of these other microscopic particles detected in the Platte River samples was amoebae, which were detected in 20 percent of the samples ( 3 of 15). Rotifers, amoebae, nematodes, and pollen were detected in at least one sample from well W90-1H. These five types of microscopic particles were detected in at least one raw water sample. None of these five types of microscopic particles were detected in finished water samples using the MPA analysis.

\section{Laser Particle Counts}

LPCs were completed on samples from all four sites (tables 10 and 11). The first sample analyzed from each site during the study (October 2002) was analyzed in eight size classifications ranging from 0.5 to $100 \mu \mathrm{m}$. All samples after that were analyzed in size classifications ranging from $1.0 \mu \mathrm{m}$ to greater than $100 \mu \mathrm{m}$. For statistical analysis (table 10), values denoted with "M" are based upon a data set that included at least one value that was not quantified (such as, <1,000). These values are not included in the summary statistics values, but are included in the total number of samples. In general, the mean LPC in each size classification decreased as size increased. Mean LPC in each size classification generally was greater in samples from the Platte River than in samples from well W90-1H, and also generally greater in samples from the raw water than in samples from the finished water. However, mean LPCs generally were greater in the raw water samples than in samples from well W90-1H. Mean total LPCs in samples from well W90-1H may have been larger than mean total laser particle counts in the raw water because one sample where $0.5-1.0 \mu \mathrm{m}$ was quantified was included in the $\mathrm{W} 90-1 \mathrm{H}$ data set, whereas this size classification was not measured in any of the raw water samples.

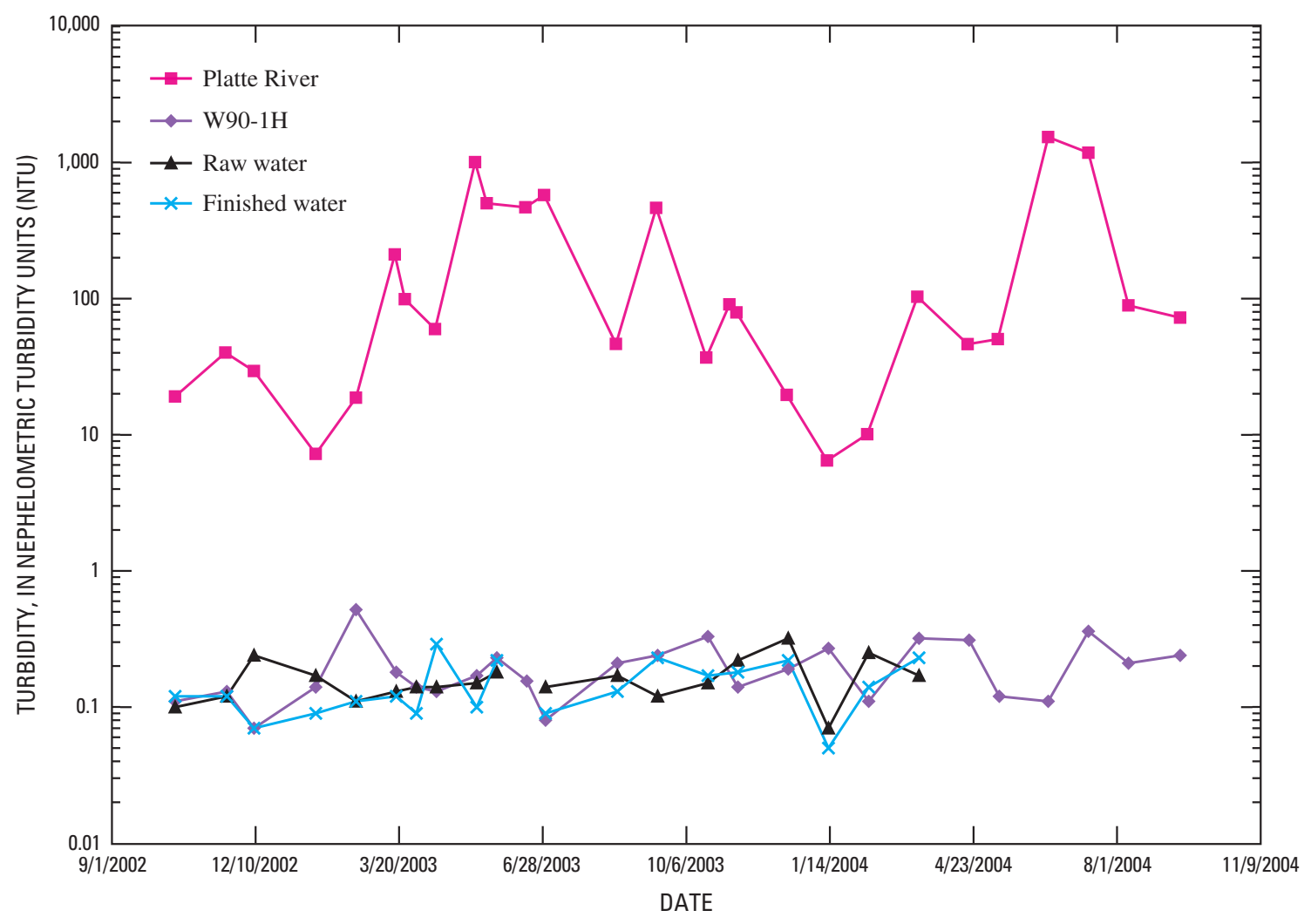

Figure 6. Turbidity at selected sites during the riverbank filtration study, Platte River, Nebraska. 


\section{Stable Hydrogen and Oxygen Isotope Ratios}

Stable hydrogen and oxygen isotope ratios were measured in surface-water (Platte River) and ground-water (wells W90-1H and W49-9) samples (fig. 8; table 12). Stable hydrogen isotope ratios of surface water showed seasonal variations ranging from $-73.1 \%$ to $-48.7 \%$ relative to VSMOW reference water. Stable oxygen isotope ratios of surface water ranged from $-9.86 \%$ o to $-6.04 \%$. Stable hydrogen isotope ratios of ground water showed seasonal variations ranging from $-71.6 \%$ to $-45.0 \%$ relative to VSMOW reference water. Stable oxygen isotope ratios of ground water ranged from $-9.82 \%$ o to $-5.25 \%$.

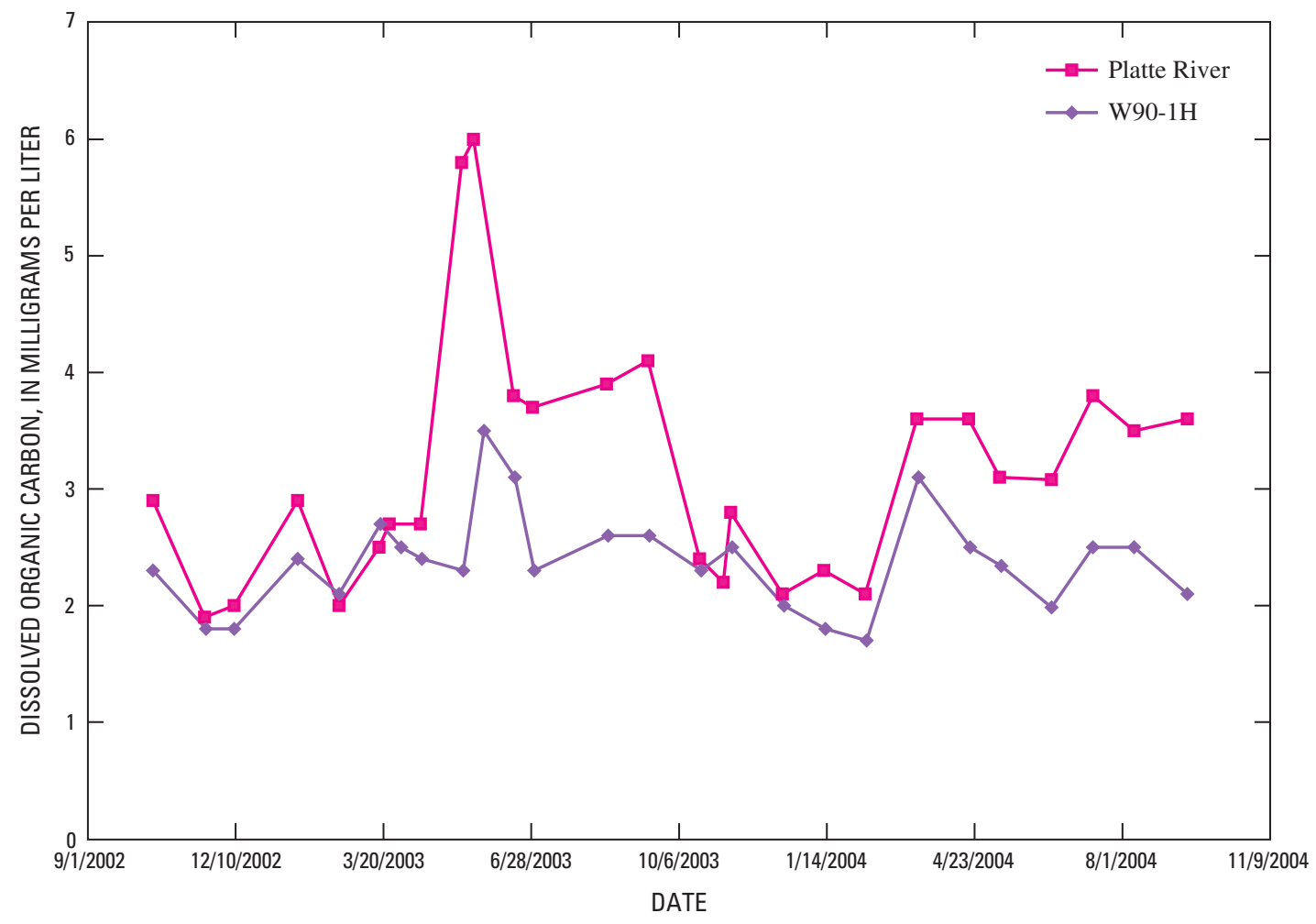

Figure 7. Dissolved organic carbon (DOC) in samples from the Platte River and collector well W90-1H during the riverbank filtration study, Platte River, Nebraska. 
26 Riverbank Filtration Study, Platte River, Nebraska, 2002 to 2004

Table 5. Cryptosporidium and Giardia concentrations in samples collected during the riverbank filtration study, Platte River, Nebraska.

[Crypto, Cryptosporidium; MDL, method detection limit; L, liter; <, less than; --, not measured]

\begin{tabular}{|c|c|c|c|c|c|c|c|c|}
\hline Site identification & Station name & Date & Crypto & Giardia & $\begin{array}{l}\text { Sample } \\
\text { volume }\end{array}$ & MDL & Crypto & Giardia \\
\hline Units --> & & & oocysts & cysts & (L) & units/L & oocysts/L & cysts/L \\
\hline \multirow{17}{*}{06801000} & \multirow{17}{*}{$\begin{array}{l}\text { Platte River near } \\
\text { Ashland }\end{array}$} & $11 / 19 / 02$ & 2 & 6 & 2.25 & .4 & 0.9 & 2.7 \\
\hline & & $12 / 9 / 02$ & 0 & 9 & 1.50 & .7 & $<\mathrm{MDL}$ & 6.0 \\
\hline & & $2 / 18 / 03$ & 0 & 2 & 3.25 & .3 & $<\mathrm{MDL}$ & .6 \\
\hline & & $3 / 17 / 03$ & 0 & 0 & 1.00 & 1.0 & $<\mathrm{MDL}$ & $<\mathrm{MDL}$ \\
\hline & & $3 / 24 / 03$ & 0 & 0 & 1.50 & .7 & $<\mathrm{MDL}$ & $<\mathrm{MDL}$ \\
\hline & & $4 / 14 / 03$ & 0 & 0 & 0.50 & 2.0 & $<\mathrm{MDL}$ & $<\mathrm{MDL}$ \\
\hline & & $6 / 29 / 03$ & 0 & 0 & .25 & 4.0 & $<\mathrm{MDL}$ & $<\mathrm{MDL}$ \\
\hline & & 8/18/03 & 0 & 0 & .50 & 2.0 & $<\mathrm{MDL}$ & $<\mathrm{MDL}$ \\
\hline & & $9 / 15 / 03$ & 1 & 0 & .25 & 4.0 & 4.0 & $<\mathrm{MDL}$ \\
\hline & & $10 / 20 / 03$ & 0 & 1 & .50 & 2.0 & $<\mathrm{MDL}$ & 2.0 \\
\hline & & $11 / 5 / 03$ & 2 & 1 & .50 & 2.0 & 4.0 & 2.0 \\
\hline & & $11 / 10 / 03$ & 2 & 0 & .50 & 2.0 & 4.0 & $<\mathrm{MDL}$ \\
\hline & & $12 / 15 / 03$ & 2 & 2 & .75 & 1.3 & 2.7 & 2.7 \\
\hline & & $1 / 12 / 04$ & 2 & 0 & 1.00 & 1.0 & 2.0 & $<\mathrm{MDL}$ \\
\hline & & $2 / 9 / 04$ & 2 & 1 & 8.50 & .1 & .2 & .1 \\
\hline & & $8 / 9 / 04$ & 0 & 0 & .50 & 2.0 & $<\mathrm{MDL}$ & $<\mathrm{MDL}$ \\
\hline & & $9 / 14 / 04$ & 0 & 0 & .50 & 2.0 & $<\mathrm{MDL}$ & $<\mathrm{MDL}$ \\
\hline \multirow[t]{11}{*}{410322096191701} & \multirow[t]{11}{*}{ W90-1H } & $10 / 15 / 02$ & -- & -- & -- & -- & -- & -- \\
\hline & & $11 / 20 / 02$ & 0 & 0 & 10.75 & .1 & $<\mathrm{MDL}$ & $<\mathrm{MDL}$ \\
\hline & & $12 / 9 / 02$ & -- & -- & -- & -- & -- & -- \\
\hline & & $1 / 21 / 03$ & -- & -- & -- & -- & -- & -- \\
\hline & & $2 / 18 / 03$ & -- & -- & -- & -- & -- & -- \\
\hline & & $3 / 18 / 03$ & -- & -- & -- & -- & -- & -- \\
\hline & & $4 / 1 / 03$ & 0 & 0 & 10.00 & .1 & $<\mathrm{MDL}$ & $<\mathrm{MDL}$ \\
\hline & & $4 / 15 / 03$ & 0 & 0 & 10.00 & .1 & $<\mathrm{MDL}$ & $<\mathrm{MDL}$ \\
\hline & & $5 / 13 / 03$ & 0 & 0 & 10.50 & .1 & $<\mathrm{MDL}$ & $<\mathrm{MDL}$ \\
\hline & & $5 / 27 / 03$ & 0 & 0 & 11.00 & .1 & $<\mathrm{MDL}$ & $<\mathrm{MDL}$ \\
\hline & & $6 / 17 / 03$ & 0 & 0 & 11.00 & .1 & $<\mathrm{MDL}$ & $<\mathrm{MDL}$ \\
\hline
\end{tabular}


Table 5. Cryptosporidium and Giardia concentrations in samples collected during the riverbank filtration study, Platte River, Nebraska.-Continued

\begin{tabular}{|c|c|c|c|c|c|c|c|c|}
\hline Site identification & Station name & Date & Crypto & Giardia & $\begin{array}{l}\text { Sample } \\
\text { volume }\end{array}$ & MDL & Crypto & Giardia \\
\hline Units --> & & & oocysts & cysts & (L) & units/L & oocysts/L & cysts/L \\
\hline \multirow{10}{*}{410322096191701} & & $8 / 19 / 03$ & 0 & 0 & 11.00 & .1 & $<\mathrm{MDL}$ & $<\mathrm{MDL}$ \\
\hline & & $9 / 16 / 03$ & -- & -- & -- & -- & -- & -- \\
\hline & & $11 / 11 / 03$ & 0 & 0 & 11.00 & .1 & $<\mathrm{MDL}$ & $<\mathrm{MDL}$ \\
\hline & & $12 / 16 / 03$ & -- & -- & -- & -- & -- & -- \\
\hline & & $1 / 13 / 04$ & -- & -- & -- & -- & -- & -- \\
\hline & & $2 / 10 / 04$ & -- & -- & -- & -- & -- & -- \\
\hline & & $6 / 14 / 04$ & 0 & 0 & 10.00 & .1 & $<\mathrm{MDL}$ & $<\mathrm{MDL}$ \\
\hline & & $7 / 12 / 04$ & 0 & 0 & 10.50 & .1 & $<\mathrm{MDL}$ & $<\mathrm{MDL}$ \\
\hline & & $8 / 9 / 04$ & 0 & 0 & 10.50 & .1 & $<\mathrm{MDL}$ & $<\mathrm{MDL}$ \\
\hline & & $9 / 14 / 04$ & 0 & 0 & 11.00 & .1 & $<\mathrm{MDL}$ & $<\mathrm{MDL}$ \\
\hline \multirow[t]{14}{*}{410315096190101} & Raw water & $10 / 15 / 02$ & -- & -- & -- & -- & -- & -- \\
\hline & & $11 / 20 / 02$ & 0 & 0 & 5.50 & .2 & $<\mathrm{MDL}$ & $<\mathrm{MDL}$ \\
\hline & & $12 / 9 / 02$ & -- & -- & -- & -- & -- & -- \\
\hline & & $5 / 27 / 03$ & 0 & 0 & 10.50 & .1 & $<\mathrm{MDL}$ & $<\mathrm{MDL}$ \\
\hline & & $6 / 17 / 03$ & 0 & 0 & 10.50 & .1 & $<\mathrm{MDL}$ & $<\mathrm{MDL}$ \\
\hline & & $6 / 30 / 03$ & 0 & 0 & 10.50 & .1 & $<\mathrm{MDL}$ & $<\mathrm{MDL}$ \\
\hline & & $8 / 19 / 03$ & 0 & 0 & 10.00 & .1 & $<\mathrm{MDL}$ & $<\mathrm{MDL}$ \\
\hline & & $9 / 16 / 03$ & -- & -- & -- & -- & -- & -- \\
\hline & & $10 / 21 / 03$ & -- & -- & -- & -- & -- & -- \\
\hline & & $11 / 11 / 03$ & 0 & 0 & 11.00 & .1 & $<\mathrm{MDL}$ & $<\mathrm{MDL}$ \\
\hline & & $12 / 16 / 03$ & -- & -- & -- & -- & -- & -- \\
\hline & & $1 / 13 / 04$ & -- & -- & -- & -- & -- & -- \\
\hline & & $2 / 10 / 04$ & -- & -- & -- & -- & -- & -- \\
\hline & & $3 / 16 / 04$ & -- & -- & -- & -- & -- & -- \\
\hline
\end{tabular}


28 Riverbank Filtration Study, Platte River, Nebraska, 2002 to 2004

Table 5. Cryptosporidium and Giardia concentrations in samples collected during the riverbank filtration study, Platte River, Nebraska.-Continued

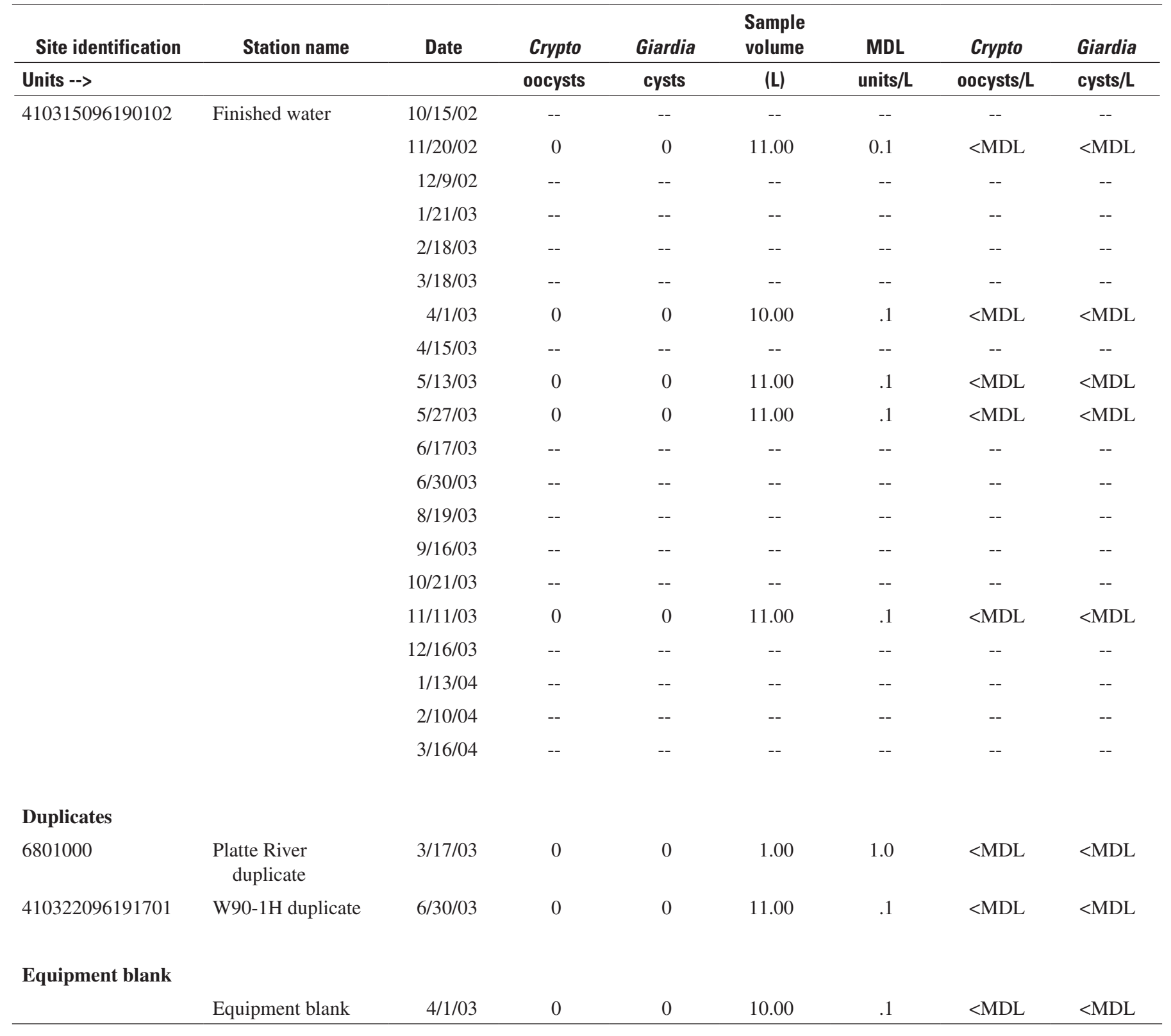


Table 6. Cryptosporidium and Giardia recovery efficiencies from analysis of samples during the riverbank filtration study, Platte River, Nebraska.

[Crypto, Cryptosporidia; CV, coefficient of variation; --, no comments]

\begin{tabular}{|c|c|c|c|}
\hline \multirow[b]{2}{*}{ Date } & \multicolumn{2}{|c|}{ Recovery efficiency } & \multirow[b]{2}{*}{ Comments } \\
\hline & $\begin{array}{c}\text { Crypto } \\
\text { (percent) }\end{array}$ & $\begin{array}{c}\text { Giardia } \\
\text { (percent) }\end{array}$ & \\
\hline $10 / 15 / 02$ & 52 & 45 & -- \\
\hline $11 / 19 / 02$ & 46 & 38 & -- \\
\hline $11 / 19 / 02$ & 29 & 25 & W90-1H matrix spike \\
\hline $12 / 9 / 02$ & 43 & 50 & - \\
\hline $12 / 9 / 02$ & 33 & 60 & Platte River matrix spike \\
\hline $1 / 21 / 03$ & 49 & 29 & -- \\
\hline $2 / 18 / 03$ & 35 & 25 & -- \\
\hline $3 / 17 / 03$ & 27 & 15 & -- \\
\hline $4 / 1 / 04$ & 39 & 14 & -- \\
\hline $4 / 14 / 03$ & 55 & 31 & -- \\
\hline $5 / 12 / 03$ & 27 & 34 & -- \\
\hline $5 / 12 / 03$ & 20 & 17 & Raw water matrix spike \\
\hline $5 / 20 / 03$ & 26 & 24 & -- \\
\hline $6 / 16 / 03$ & 24 & 65 & -- \\
\hline $6 / 29 / 03$ & 45 & 39 & -- \\
\hline $8 / 18 / 03$ & 58 & 64 & -- \\
\hline $9 / 15 / 03$ & 57 & 49 & -- \\
\hline $10 / 20 / 03$ & 10 & 19 & -- \\
\hline $11 / 5 / 03$ & 66 & 57 & -- \\
\hline $12 / 15 / 03$ & 66 & 57 & -- \\
\hline $1 / 12 / 04$ & 12 & 28 & -- \\
\hline 2/9/04 & 53 & 55 & -- \\
\hline $3 / 15 / 04$ & 46 & 28 & -- \\
\hline 4/19/04 & 53 & 41 & -- \\
\hline $5 / 10 / 04$ & 48 & 53 & -- \\
\hline $6 / 14 / 04$ & 60 & 46 & -- \\
\hline $7 / 12 / 04$ & 43 & 39 & -- \\
\hline 8/9/04 & 38 & 40 & -- \\
\hline $9 / 14 / 04$ & 56 & 52 & -- \\
\hline Mean & 42 & 39 & -- \\
\hline CV (percent) & 36.5 & 38.7 & -- \\
\hline
\end{tabular}


Table 7. Total coliform, E. coli, male-specific and somatic coliphage, aerobic spore, and enterococci concentrations in samples collected during the riverbank filtration study, Platte River, Nebraska.

[cfu, colony forming units; $\mathrm{mL}$, milliliter; pfu, plaque forming units; mpn, most probable number; <, less than; >, greater than; --, not measured; E, estimated; NA, not applicable]

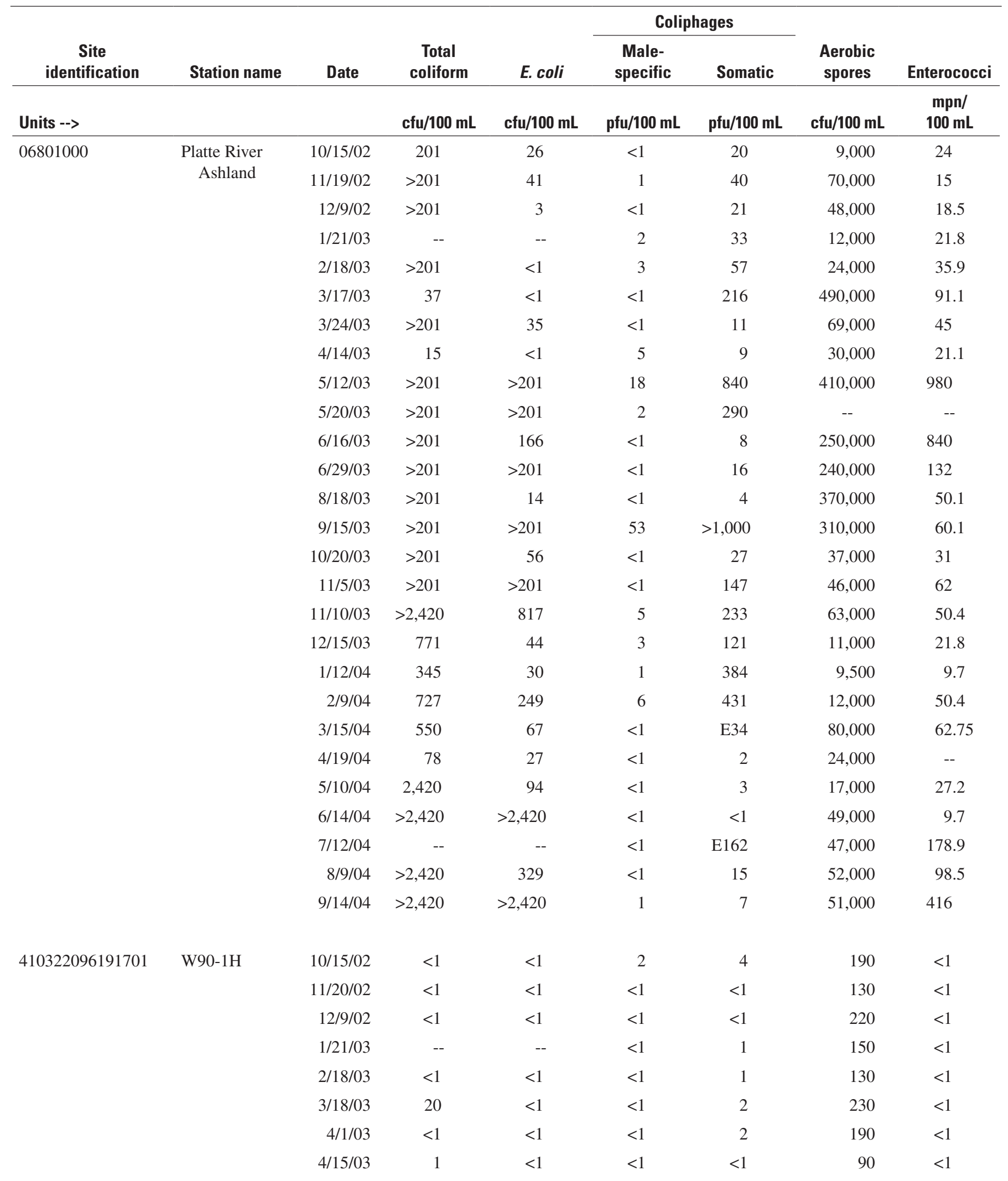


Table 7. Total coliform, E. coli, male-specific and somatic coliphage, aerobic spore, and enterococci concentrations in samples collected during the riverbank filtration study, Platte River, Nebraska.-Continued

\begin{tabular}{|c|c|c|c|c|c|c|c|c|}
\hline \multirow[b]{2}{*}{$\begin{array}{c}\text { Site } \\
\text { identification }\end{array}$} & \multirow[b]{2}{*}{ Station name } & \multirow[b]{2}{*}{ Date } & \multirow[b]{2}{*}{$\begin{array}{c}\text { Total } \\
\text { coliform }\end{array}$} & \multirow[b]{2}{*}{ E. coli } & \multicolumn{2}{|c|}{ Coliphages } & \multirow[b]{2}{*}{$\begin{array}{c}\text { Aerobic } \\
\text { spores }\end{array}$} & \multirow[b]{2}{*}{ Enterococci } \\
\hline & & & & & $\begin{array}{c}\text { Male- } \\
\text { specific }\end{array}$ & Somatic & & \\
\hline \multirow[t]{14}{*}{410322096191701} & W90-1H & $5 / 13 / 03$ & 5 & $<1$ & $<1$ & $<1$ & 340 & $<1$ \\
\hline & & $6 / 30 / 03$ & 1 & $<1$ & $<1$ & $<1$ & 100 & $<1$ \\
\hline & & $8 / 19 / 03$ & $<1$ & $<1$ & $<1$ & $<1$ & 260 & $<1$ \\
\hline & & $9 / 16 / 03$ & $<1$ & $<1$ & $<1$ & $<1$ & 180 & $<1$ \\
\hline & & $10 / 21 / 03$ & $<1$ & $<1$ & $<1$ & $<1$ & 835 & $<1$ \\
\hline & & $1 / 13 / 04$ & $<1$ & $<1$ & $<1$ & $<1$ & 60 & $<1$ \\
\hline & & $2 / 10 / 04$ & $<1$ & $<1$ & $<1$ & $<1$ & 55 & $<1$ \\
\hline & & $3 / 16 / 04$ & 14 & 1 & 1 & 16 & 190 & $<1$ \\
\hline & & $4 / 20 / 04$ & 1 & $<1$ & $<1$ & $<1$ & 330 & -- \\
\hline & & $5 / 11 / 04$ & -- & -- & $<1$ & $<1$ & 80 & $<1$ \\
\hline & & $6 / 14 / 04$ & $<1$ & $<1$ & $<1$ & $<1$ & 77 & $<1$ \\
\hline & & $7 / 12 / 04$ & -- & -- & $<1$ & $<1$ & 52 & $<1$ \\
\hline & & $8 / 9 / 04$ & $<1$ & $<1$ & $<1$ & $<1$ & 175 & $<1$ \\
\hline & & $9 / 14 / 04$ & $<1$ & $<1$ & $<1$ & $<1$ & 140 & $<1$ \\
\hline \multirow{13}{*}{410315096190101} & & $2 / 18 / 03$ & $<1$ & $<1$ & -- & -- & 70 & $<1$ \\
\hline & & $3 / 18 / 03$ & 4 & $<1$ & 1 & 1 & 90 & $<1$ \\
\hline & & $4 / 1 / 03$ & 1 & $<1$ & $<1$ & $<1$ & 70 & $<1$ \\
\hline & & $4 / 15 / 03$ & $<1$ & $<1$ & -- & -- & 30 & $<1$ \\
\hline & & $5 / 13 / 03$ & $<1$ & $<1$ & $<1$ & $<1$ & 20 & $<1$ \\
\hline & & $5 / 27 / 03$ & $<1$ & $<1$ & $<1$ & $<1$ & -- & -- \\
\hline & & $6 / 17 / 03$ & $<1$ & $<1$ & -- & -- & 40 & $<1$ \\
\hline & & $6 / 30 / 03$ & $<1$ & $<1$ & $<1$ & $<1$ & 51 & $<1$ \\
\hline & & 8/19/03 & $<1$ & $<1$ & -- & -- & 65 & $<1$ \\
\hline & & $9 / 16 / 03$ & $<1$ & $<1$ & $<1$ & $<1$ & 930 & $<1$ \\
\hline & & $10 / 21 / 03$ & $<1$ & $<1$ & -- & -- & 6 & $<1$ \\
\hline & & $11 / 11 / 03$ & $<1$ & $<1$ & $<1$ & $<1$ & $<1$ & $<1$ \\
\hline & & $12 / 16 / 03$ & $<1$ & $<1$ & -- & -- & 40 & $<1$ \\
\hline
\end{tabular}


Table 7. Total coliform, E. coli, male-specific and somatic coliphage, aerobic spore, and enterococci concentrations in samples collected during the riverbank filtration study, Platte River, Nebraska.-Continued

\begin{tabular}{|c|c|c|c|c|c|c|c|c|}
\hline \multirow[b]{2}{*}{$\begin{array}{c}\text { Site } \\
\text { identification } \\
\end{array}$} & \multirow[b]{2}{*}{ Station name } & \multirow[b]{2}{*}{ Date } & \multirow[b]{2}{*}{$\begin{array}{c}\text { Total } \\
\text { coliform }\end{array}$} & \multirow[b]{2}{*}{ E. coli } & \multicolumn{2}{|c|}{ Coliphages } & \multirow[b]{2}{*}{$\begin{array}{c}\text { Aerobic } \\
\text { spores }\end{array}$} & \multirow[b]{2}{*}{ Enterococci } \\
\hline & & & & & $\begin{array}{l}\text { Male- } \\
\text { specific }\end{array}$ & Somatic & & \\
\hline Units --> & & & cfu/100 mL & cfu/100 mL & pfu/100 mL & pfu/100 mL & cfu/100 mL & $\begin{array}{c}\mathrm{mpn} / \\
100 \mathrm{~mL}\end{array}$ \\
\hline \multirow[t]{3}{*}{410315096190101} & \multirow[t]{3}{*}{ Raw water } & $1 / 13 / 04$ & $<1$ & $<1$ & $<1$ & $<1$ & 15 & $<1$ \\
\hline & & $2 / 10 / 04$ & $<1$ & $<1$ & -- & -- & 30 & $<1$ \\
\hline & & $3 / 16 / 04$ & 4 & $<1$ & $<1$ & 1 & 83 & 1 \\
\hline \multirow[t]{20}{*}{410315096190102} & \multirow[t]{20}{*}{ Finished water } & $10 / 15 / 02$ & $<1$ & $<1$ & -- & -- & 3 & $<1$ \\
\hline & & $11 / 20 / 02$ & $<1$ & $<1$ & $<1$ & $<1$ & $<1$ & $<1$ \\
\hline & & $12 / 9 / 02$ & $<1$ & $<1$ & -- & -- & $<1$ & $<1$ \\
\hline & & $1 / 21 / 03$ & -- & -- & 1 & $<1$ & $<1$ & $<1$ \\
\hline & & 2/18/03 & $<1$ & $<1$ & -- & -- & $<1$ & $<1$ \\
\hline & & $3 / 18 / 03$ & $<1$ & $<1$ & $<1$ & $<1$ & 3 & $<1$ \\
\hline & & $4 / 1 / 03$ & $<1$ & $<1$ & 1 & 1 & $<1$ & $<1$ \\
\hline & & $4 / 15 / 03$ & $<1$ & $<1$ & -- & -- & 4 & $<1$ \\
\hline & & $5 / 13 / 03$ & $<1$ & $<1$ & $<1$ & $<1$ & $<1$ & $<1$ \\
\hline & & $5 / 27 / 03$ & $<1$ & $<1$ & $<1$ & $<1$ & -- & -- \\
\hline & & $6 / 17 / 03$ & $<1$ & $<1$ & -- & -- & 3 & $<1$ \\
\hline & & 6/30/03 & $<1$ & $<1$ & $<1$ & $<1$ & $<1$ & $<1$ \\
\hline & & $8 / 19 / 03$ & $<1$ & $<1$ & -- & -- & $<1$ & $<1$ \\
\hline & & $9 / 16 / 03$ & $<1$ & $<1$ & $<1$ & $<1$ & $<1$ & $<1$ \\
\hline & & $10 / 21 / 03$ & $<1$ & $<1$ & -- & -- & $<1$ & $<1$ \\
\hline & & $11 / 11 / 03$ & $<1$ & $<1$ & $<1$ & $<1$ & $<1$ & $<1$ \\
\hline & & $12 / 16 / 03$ & $<1$ & $<1$ & -- & -- & $<1$ & $<1$ \\
\hline & & $1 / 13 / 04$ & $<1$ & $<1$ & $<1$ & $<1$ & $<1$ & $<1$ \\
\hline & & $2 / 10 / 04$ & $<1$ & $<1$ & -- & -- & $<1$ & $<1$ \\
\hline & & $3 / 16 / 04$ & $<1$ & $<1$ & $<1$ & $<1$ & $<1$ & $<1$ \\
\hline \multicolumn{9}{|l|}{ Duplicates } \\
\hline 06801000 & $\begin{array}{r}\text { Platte River } \\
\text { duplicate }\end{array}$ & $10 / 20 / 03$ & -- & -- & $<1$ & 27 & -- & -- \\
\hline \multirow[t]{2}{*}{410322096191701} & \multirow{2}{*}{$\begin{array}{l}\text { W90-1H } \\
\text { duplicate }\end{array}$} & $4 / 15 / 03$ & -- & -- & $<1$ & $<1$ & -- & -- \\
\hline & & $3 / 16 / 04$ & -- & -- & $<1$ & 9 & -- & -- \\
\hline \multirow[t]{2}{*}{410315096190101} & \multirow{2}{*}{$\begin{array}{l}\text { Raw water } \\
\text { duplicate }\end{array}$} & $5 / 13 / 03$ & -- & -- & $<1$ & $<1$ & -- & -- \\
\hline & & $1 / 13 / 04$ & -- & -- & $<1$ & $<1$ & -- & -- \\
\hline 410315096190102 & $\begin{array}{l}\text { Finished water } \\
\text { duplicate }\end{array}$ & $9 / 16 / 03$ & -- & -- & $<1$ & $<1$ & -- & -- \\
\hline \multicolumn{9}{|l|}{ Equipment blank } \\
\hline NA & $\begin{array}{l}\text { Equipment } \\
\text { blank }\end{array}$ & $6 / 18 / 03$ & -- & -- & $<1$ & $<1$ & -- & -- \\
\hline
\end{tabular}


Table 8. Summary statistics of microscopic particulate analysis concentrations in samples collected during riverbank filtration study, Platte River, Nebraska.

[Summary statistics are based on quantified concentrations; MDL, method detection limit; units are in organisms per 100 liters; $\mathrm{n}$, number of samples; det, number of detections; max, maximum; med, median; std. dev., standard deviation; na, not applicable; x.xeyy, x.x times 10 raised to the yy power, for example, $2.5 \mathrm{e} 10$ is 2.5 times $10^{10}$ ]

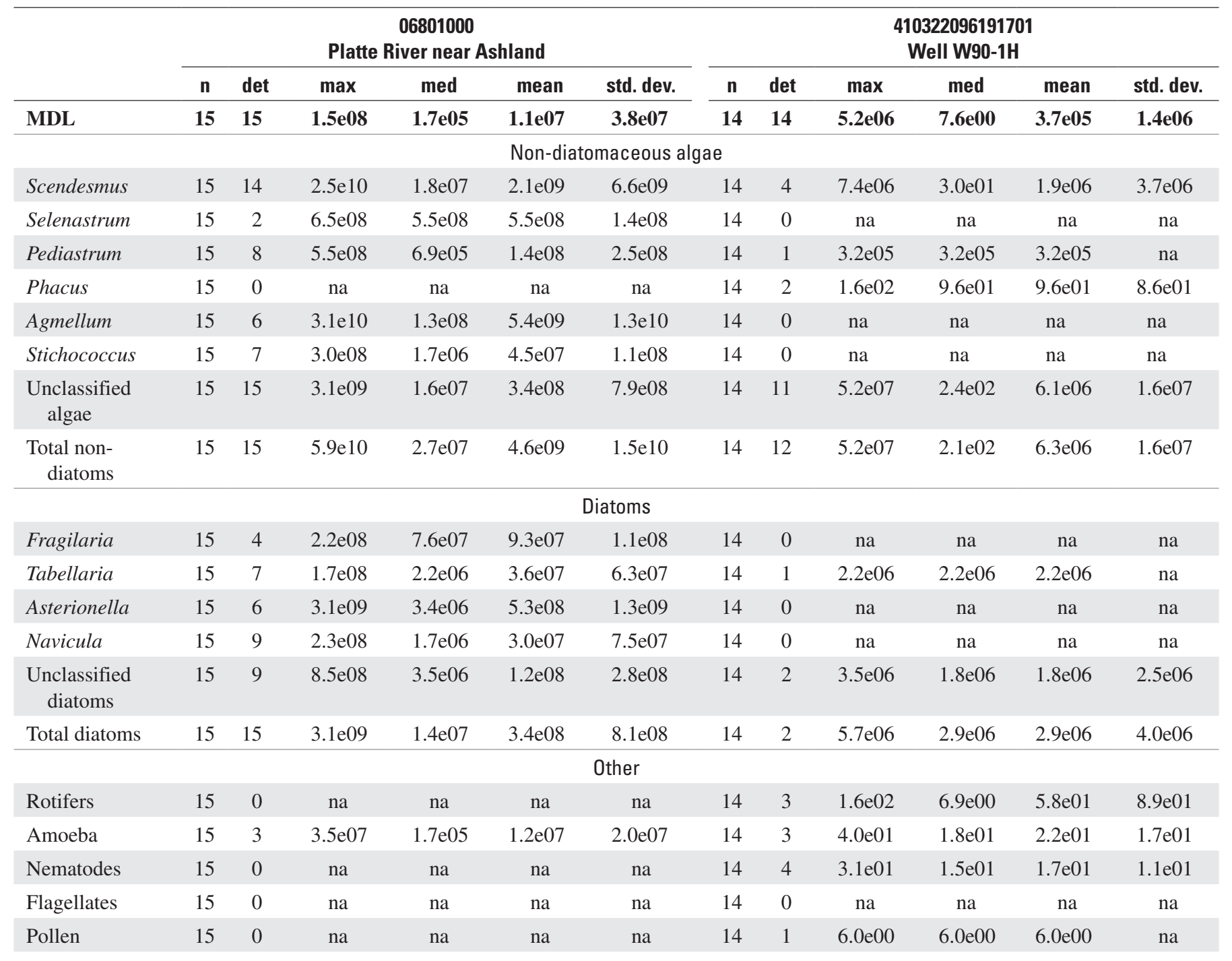


Table 8. Summary statistics of microscopic particulate analysis concentrations in samples collected during riverbank filtration study, Platte River, Nebraska.-Continued

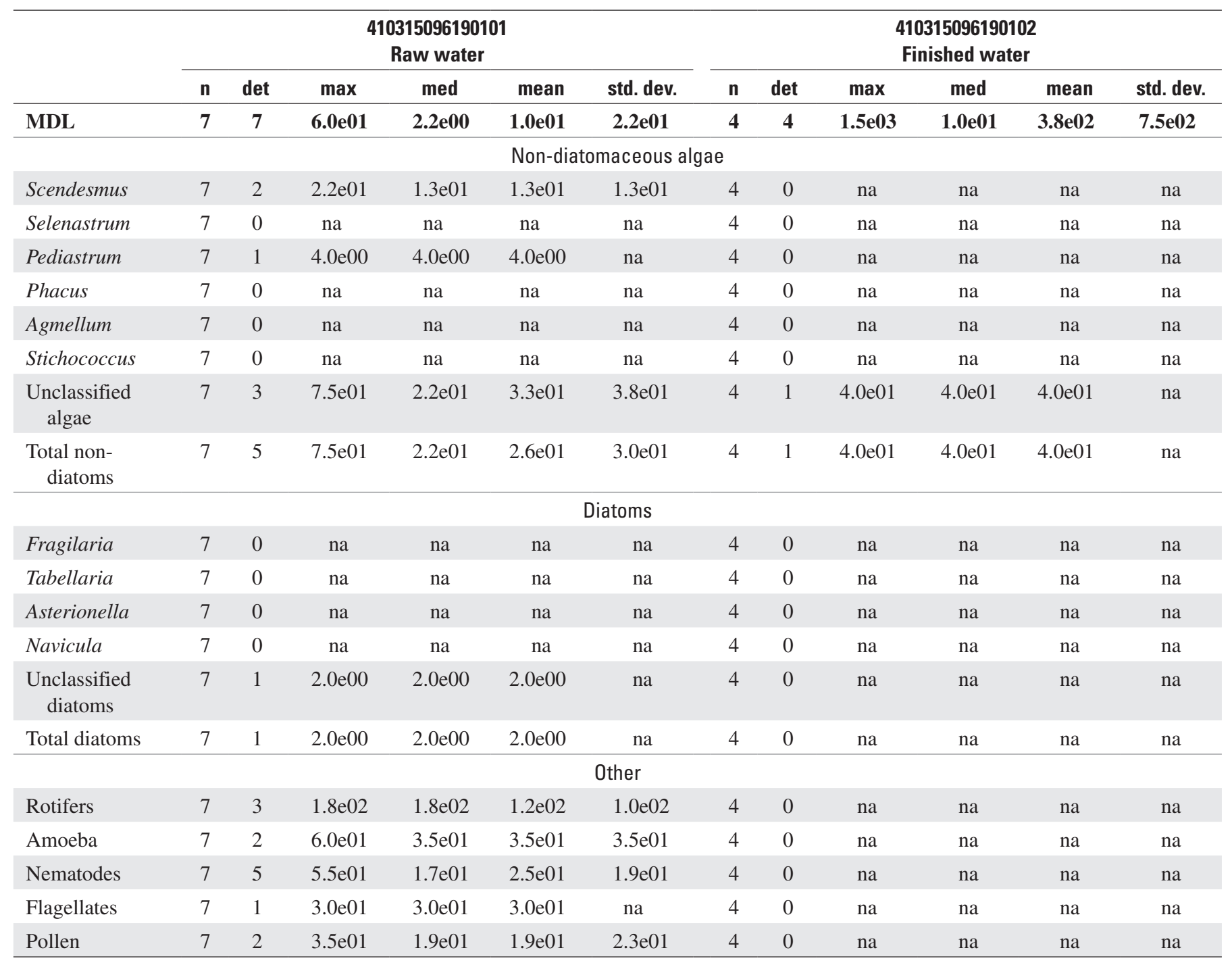


Table 9. Microscopic particulate analysis concentrations in samples collected during the riverbank filtration study, Platte River, Nebraska.

[MDL, method detection limit; L, liter; unclass., unclassified; --, not measured or not applicable; <, less than; m, organism detected but not quantified; large amorphous debris is greater than 5 micrometers in diameter; fine amorphous debris is 1 to 5 micrometers in diameter; NA, not applicable; - , no comments; $\mathrm{x} . \mathrm{xE}+\mathrm{y}, \mathrm{x} . \mathrm{x}$ times 10 raised to the y power, for example, $2.0 \mathrm{E}+1$ is 2.0 times $10^{1}$ ]

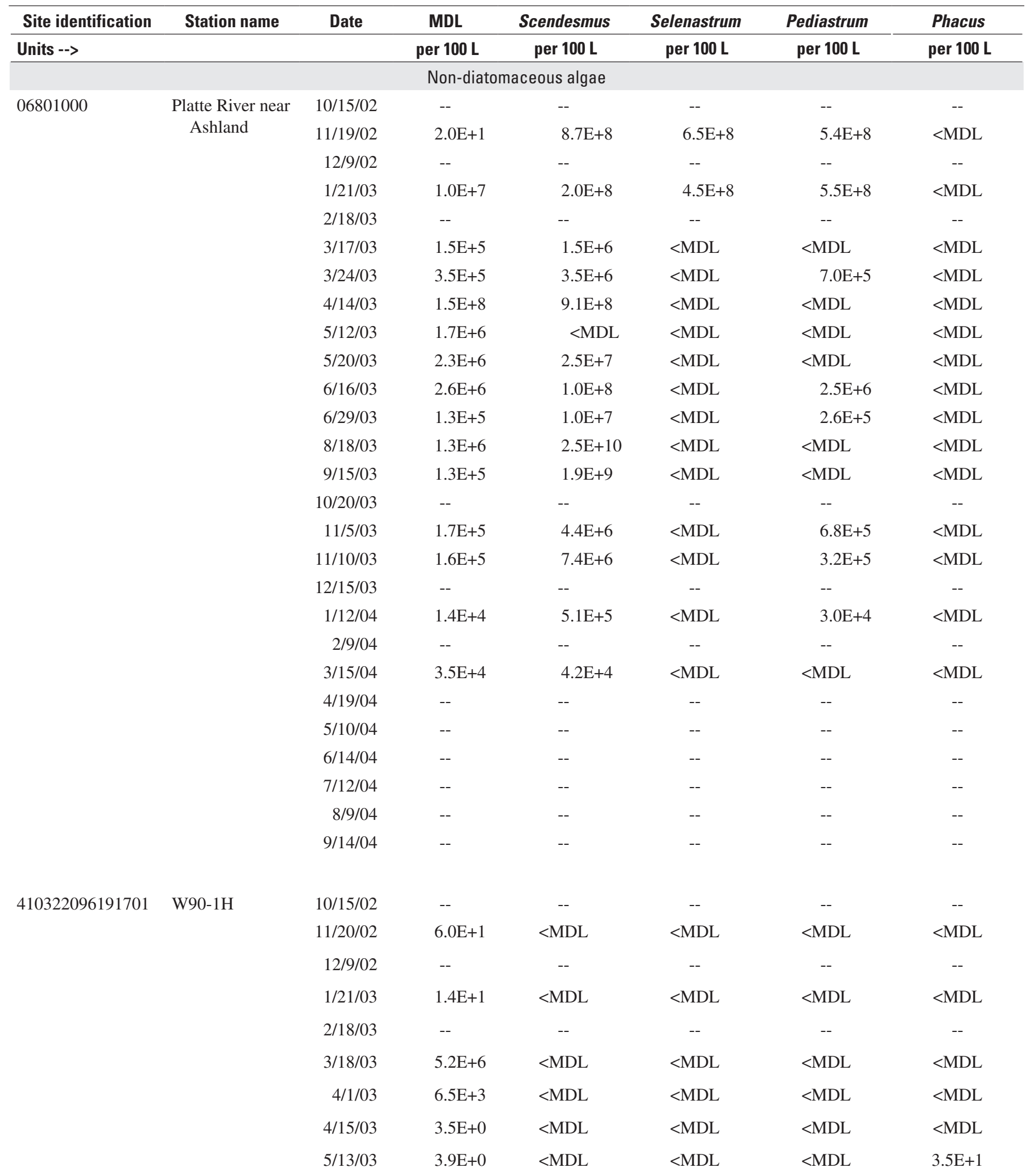


Table 9. Microscopic particulate analysis concentrations in samples collected during the riverbank filtration study, Platte River, Nebraska.-Continued

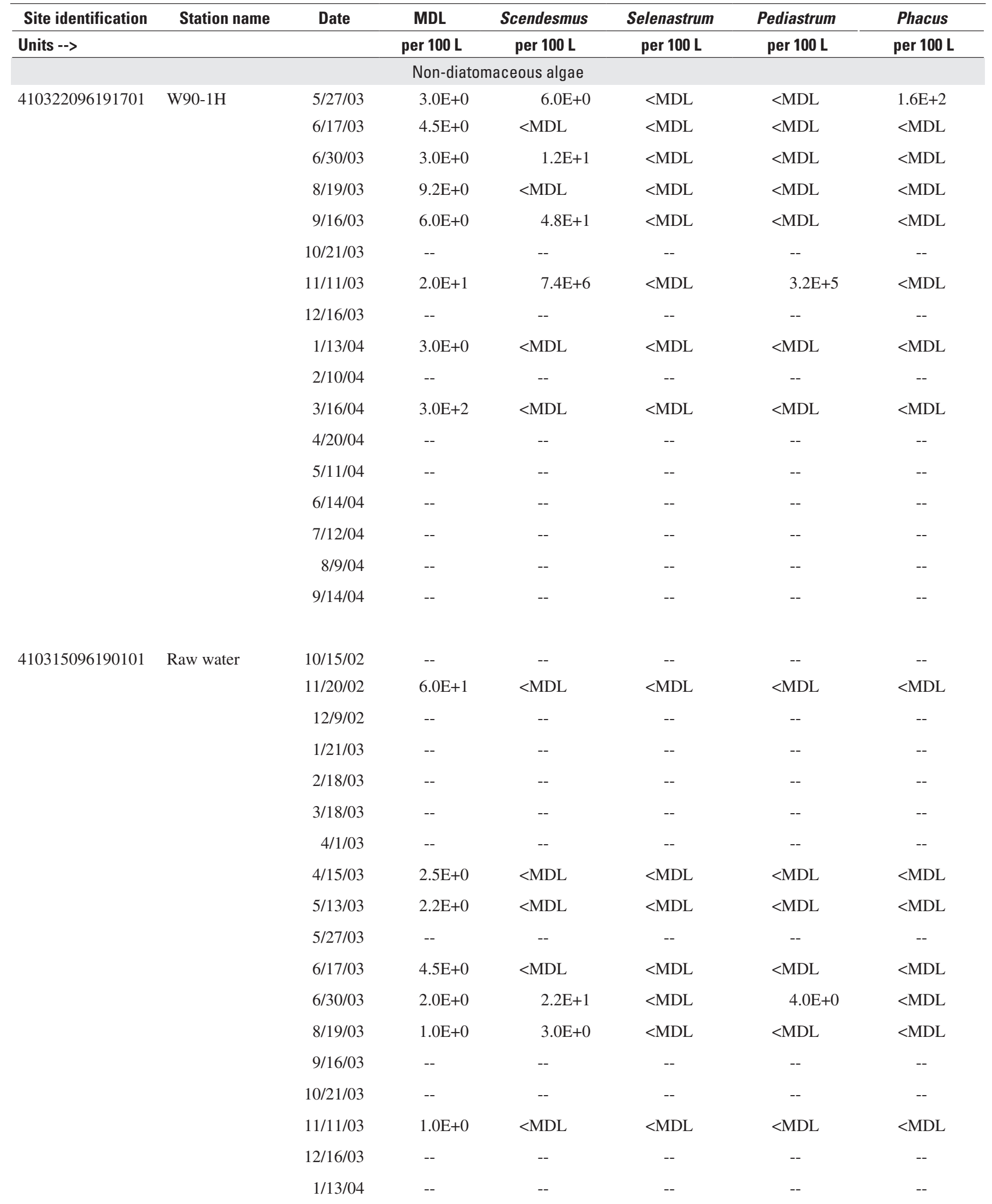


Table 9. Microscopic particulate analysis concentrations in samples collected during the riverbank filtration study, Platte River, Nebraska.-Continued

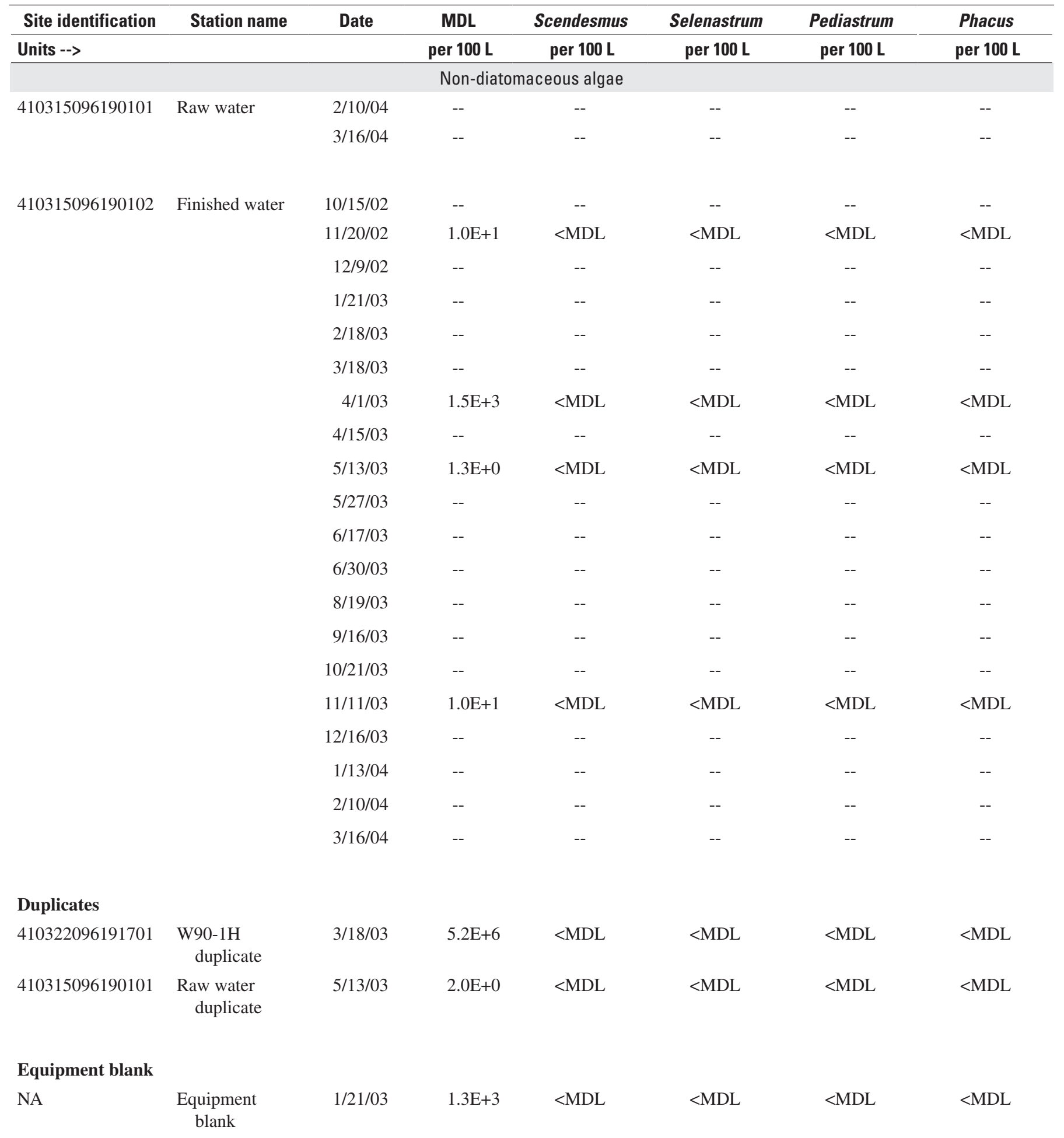


Table 9. Microscopic particulate analysis concentrations in samples collected during the riverbank filtration study, Platte River, Nebraska.-Continued

\begin{tabular}{|c|c|c|c|c|c|c|}
\hline Site identification & Station name & Date & Agmellum & Stichococcus & $\begin{array}{c}\text { Unclassified } \\
\text { algae }\end{array}$ & $\begin{array}{c}\text { Total non- } \\
\text { diatoms }\end{array}$ \\
\hline Units --> & & & per $100 \mathrm{~L}$ & per $100 \mathrm{~L}$ & per $100 \mathrm{~L}$ & per $100 \mathrm{~L}$ \\
\hline \multicolumn{7}{|c|}{ Non-diatomaceous algae } \\
\hline \multirow[t]{27}{*}{06801000} & Platte River near & $10 / 15 / 02$ & -- & -- & -- & -- \\
\hline & Ashland & $11 / 19 / 02$ & $<\mathrm{MDL}$ & $<\mathrm{MDL}$ & $5.4 \mathrm{E}+8$ & $2.6 \mathrm{E}+9$ \\
\hline & & $12 / 9 / 02$ & -- & -- & -- & -- \\
\hline & & $1 / 21 / 03$ & $2.5 \mathrm{E}+8$ & $<\mathrm{MDL}$ & $5.5 \mathrm{E}+8$ & $2.0 \mathrm{E}+9$ \\
\hline & & $2 / 18 / 03$ & -- & -- & -- & -- \\
\hline & & $3 / 17 / 03$ & $4.5 \mathrm{E}+5$ & $4.5 \mathrm{E}+5$ & $6.0 \mathrm{E}+6$ & $8.4 \mathrm{E}+6$ \\
\hline & & $3 / 24 / 03$ & $<\mathrm{MDL}$ & $7.0 \mathrm{E}+5$ & $6.6 \mathrm{E}+6$ & $1.2 \mathrm{E}+7$ \\
\hline & & $4 / 14 / 03$ & $<\mathrm{MDL}$ & $3.0 \mathrm{E}+8$ & $3.0 \mathrm{E}+8$ & $1.5 \mathrm{E}+9$ \\
\hline & & $5 / 12 / 03$ & $<\mathrm{MDL}$ & $<\mathrm{MDL}$ & $3.4 \mathrm{E}+6$ & $3.4 \mathrm{E}+6$ \\
\hline & & $5 / 20 / 03$ & $<\mathrm{MDL}$ & $6.9 \mathrm{E}+6$ & $4.4 \mathrm{E}+7$ & $7.6 \mathrm{E}+7$ \\
\hline & & $6 / 16 / 03$ & $<\mathrm{MDL}$ & $5.0 \mathrm{E}+6$ & $3.3 \mathrm{E}+8$ & $4.4 \mathrm{E}+8$ \\
\hline & & $6 / 29 / 03$ & $<\mathrm{MDL}$ & $1.0 \mathrm{E}+6$ & $1.6 \mathrm{E}+7$ & $2.7 \mathrm{E}+7$ \\
\hline & & $8 / 18 / 03$ & $3.1 \mathrm{E}+10$ & $<\mathrm{MDL}$ & $3.1 \mathrm{E}+9$ & $5.9 \mathrm{E}+10$ \\
\hline & & $9 / 15 / 03$ & $8.9 \mathrm{E}+8$ & $<\mathrm{MDL}$ & $1.9 \mathrm{E}+8$ & $3.0 \mathrm{E}+9$ \\
\hline & & $10 / 20 / 03$ & -- & -- & -- & -- \\
\hline & & $11 / 5 / 03$ & $<\mathrm{MDL}$ & $1.7 \mathrm{E}+6$ & $5.1 \mathrm{E}+6$ & $1.2 \mathrm{E}+7$ \\
\hline & & $11 / 10 / 03$ & $<\mathrm{MDL}$ & $<\mathrm{MDL}$ & $1.5 \mathrm{E}+7$ & $2.3 \mathrm{E}+7$ \\
\hline & & $12 / 15 / 03$ & -- & -- & -- & -- \\
\hline & & $1 / 12 / 04$ & $3.0 \mathrm{E}+4$ & $<\mathrm{MDL}$ & $6.9 \mathrm{E}+5$ & $1.3 \mathrm{E}+6$ \\
\hline & & $2 / 9 / 04$ & -- & -- & -- & -- \\
\hline & & $3 / 15 / 04$ & $7.0 \mathrm{E}+4$ & $<\mathrm{MDL}$ & $3.5 \mathrm{E}+5$ & $4.6 \mathrm{E}+5$ \\
\hline & & $4 / 19 / 04$ & -- & -- & -- & -- \\
\hline & & $5 / 10 / 04$ & -- & -- & -- & -- \\
\hline & & $6 / 14 / 04$ & -- & -- & -- & -- \\
\hline & & $7 / 12 / 04$ & -- & -- & -- & -- \\
\hline & & $8 / 9 / 04$ & -- & -- & -- & -- \\
\hline & & $9 / 14 / 04$ & -- & -- & -- & -- \\
\hline \multirow[t]{9}{*}{410322096191701} & W90-1H & $10 / 15 / 02$ & -- & -- & -- & -- \\
\hline & & $11 / 20 / 02$ & $<\mathrm{MDL}$ & $<\mathrm{MDL}$ & $<\mathrm{MDL}$ & $<\mathrm{MDL}$ \\
\hline & & $12 / 9 / 02$ & -- & -- & -- & -- \\
\hline & & $1 / 21 / 03$ & $<\mathrm{MDL}$ & $<\mathrm{MDL}$ & $<\mathrm{MDL}$ & $<\mathrm{MDL}$ \\
\hline & & $2 / 18 / 03$ & -- & -- & -- & -- \\
\hline & & $3 / 18 / 03$ & $<\mathrm{MDL}$ & $<\mathrm{MDL}$ & $5.2 \mathrm{E}+7$ & $5.2 \mathrm{E}+7$ \\
\hline & & $4 / 1 / 03$ & $<\mathrm{MDL}$ & $<\mathrm{MDL}$ & $5.6 \mathrm{E}+5$ & $5.6 \mathrm{E}+5$ \\
\hline & & 4/15/03 & $<\mathrm{MDL}$ & $<\mathrm{MDL}$ & $1.9 \mathrm{E}+2$ & $1.9 \mathrm{E}+2$ \\
\hline & & $5 / 13 / 03$ & $<\mathrm{MDL}$ & $<\mathrm{MDL}$ & $5.9 \mathrm{E}+1$ & $9.4 \mathrm{E}+1$ \\
\hline
\end{tabular}


Table 9. Microscopic particulate analysis concentrations in samples collected during the riverbank filtration study, Platte River, Nebraska.-Continued

\begin{tabular}{|c|c|c|c|c|c|c|}
\hline Site identification & Station name & Date & Agmellum & Stichococcus & $\begin{array}{c}\text { Unclassified } \\
\text { algae }\end{array}$ & $\begin{array}{c}\text { Total non- } \\
\text { diatoms }\end{array}$ \\
\hline Units --> & & & per $100 \mathrm{~L}$ & per $100 \mathrm{~L}$ & per $100 \mathrm{~L}$ & per $100 \mathrm{~L}$ \\
\hline \multicolumn{7}{|c|}{ Non-diatomaceous algae } \\
\hline \multirow[t]{17}{*}{410322096191701} & W90-1H & $5 / 27 / 03$ & $<\mathrm{MDL}$ & $<\mathrm{MDL}$ & $4.5 \mathrm{E}+2$ & $6.2 \mathrm{E}+2$ \\
\hline & & $6 / 17 / 03$ & $<\mathrm{MDL}$ & $<\mathrm{MDL}$ & $9.0 \mathrm{E}+0$ & $9.0 \mathrm{E}+0$ \\
\hline & & $6 / 30 / 03$ & $<\mathrm{MDL}$ & $<\mathrm{MDL}$ & $3.6 \mathrm{E}+1$ & $4.8 \mathrm{E}+1$ \\
\hline & & $8 / 19 / 03$ & $<\mathrm{MDL}$ & $<\mathrm{MDL}$ & $2.4 \mathrm{E}+2$ & $2.4 \mathrm{E}+2$ \\
\hline & & $9 / 16 / 03$ & $<\mathrm{MDL}$ & $<\mathrm{MDL}$ & $<\mathrm{MDL}$ & $4.8 \mathrm{E}+1$ \\
\hline & & $10 / 21 / 03$ & -- & -- & -- & -- \\
\hline & & $11 / 11 / 03$ & $<\mathrm{MDL}$ & $<\mathrm{MDL}$ & $1.5 \mathrm{E}+7$ & $2.3 \mathrm{E}+7$ \\
\hline & & $12 / 16 / 03$ & -- & -- & -- & -- \\
\hline & & $1 / 13 / 04$ & $<\mathrm{MDL}$ & $<\mathrm{MDL}$ & $3.0 \mathrm{E}+0$ & $3.0 \mathrm{E}+0$ \\
\hline & & $2 / 10 / 04$ & -- & -- & -- & -- \\
\hline & & $3 / 16 / 04$ & $<\mathrm{MDL}$ & $<\mathrm{MDL}$ & $3.0 \mathrm{E}+4$ & $3.0 \mathrm{E}+4$ \\
\hline & & $4 / 20 / 04$ & -- & -- & -- & -- \\
\hline & & $5 / 11 / 04$ & -- & -- & -- & -- \\
\hline & & $6 / 14 / 04$ & -- & -- & -- & -- \\
\hline & & $7 / 12 / 04$ & -- & -- & -- & -- \\
\hline & & $8 / 9 / 04$ & -- & -- & -- & -- \\
\hline & & $9 / 14 / 04$ & -- & -- & -- & -- \\
\hline \multirow[t]{17}{*}{410315096190101} & Raw water & $10 / 15 / 02$ & $<\mathrm{MDL}$ & -- & -- & -- \\
\hline & & $11 / 20 / 02$ & -- & $<\mathrm{MDL}$ & $<\mathrm{MDL}$ & $<\mathrm{MDL}$ \\
\hline & & $12 / 9 / 02$ & -- & -- & -- & -- \\
\hline & & $1 / 21 / 03$ & -- & -- & -- & -- \\
\hline & & $2 / 18 / 03$ & -- & -- & -- & -- \\
\hline & & $3 / 18 / 03$ & -- & -- & -- & -- \\
\hline & & $4 / 1 / 03$ & $<\mathrm{MDL}$ & -- & -- & -- \\
\hline & & $4 / 15 / 03$ & $<\mathrm{MDL}$ & $<\mathrm{MDL}$ & $7.5 \mathrm{E}+1$ & $7.5 \mathrm{E}+1$ \\
\hline & & $5 / 13 / 03$ & -- & $<\mathrm{MDL}$ & $2.2 \mathrm{E}+1$ & $2.2 \mathrm{E}+1$ \\
\hline & & $5 / 27 / 03$ & $<\mathrm{MDL}$ & -- & -- & -- \\
\hline & & $6 / 17 / 03$ & $<\mathrm{MDL}$ & $<\mathrm{MDL}$ & $<\mathrm{MDL}$ & $<\mathrm{MDL}$ \\
\hline & & $6 / 30 / 03$ & $<\mathrm{MDL}$ & $<\mathrm{MDL}$ & $<\mathrm{MDL}$ & $2.6 \mathrm{E}+1$ \\
\hline & & $8 / 19 / 03$ & -- & $<\mathrm{MDL}$ & $<\mathrm{MDL}$ & $3.0 \mathrm{E}+0$ \\
\hline & & $9 / 16 / 03$ & -- & -- & -- & -- \\
\hline & & $10 / 21 / 03$ & $<\mathrm{MDL}$ & -- & -- & -- \\
\hline & & $11 / 11 / 03$ & -- & $<\mathrm{MDL}$ & $2.0 \mathrm{E}+0$ & $2.0 \mathrm{E}+0$ \\
\hline & & $12 / 16 / 03$ & -- & -- & -- & -- \\
\hline
\end{tabular}


Table 9. Microscopic particulate analysis concentrations in samples collected during the riverbank filtration study, Platte River, Nebraska.-Continued

\begin{tabular}{|c|c|c|c|c|c|c|}
\hline Site identification & Station name & Date & Agmellum & Stichococcus & $\begin{array}{c}\text { Unclassified } \\
\text { algae }\end{array}$ & $\begin{array}{c}\text { Total non- } \\
\text { diatoms }\end{array}$ \\
\hline Units --> & & & per $100 \mathrm{~L}$ & per $100 \mathrm{~L}$ & per $100 \mathrm{~L}$ & per $100 \mathrm{~L}$ \\
\hline \multicolumn{7}{|c|}{ Non-diatomaceous algae } \\
\hline \multirow[t]{3}{*}{410315096190101} & Raw water & $1 / 13 / 04$ & & -- & -- & -- \\
\hline & & $2 / 10 / 04$ & -- & -- & -- & -- \\
\hline & & $3 / 16 / 04$ & -- & -- & -- & -- \\
\hline \multirow[t]{20}{*}{410315096190102} & Finished water & $10 / 15 / 02$ & -- & -- & -- & -- \\
\hline & & $11 / 20 / 02$ & $<\mathrm{MDL}$ & $<\mathrm{MDL}$ & $4.0 \mathrm{E}+1$ & $4.0 \mathrm{E}+1$ \\
\hline & & $12 / 9 / 02$ & -- & -- & -- & -- \\
\hline & & $1 / 21 / 03$ & -- & -- & -- & -- \\
\hline & & $2 / 18 / 03$ & -- & -- & -- & -- \\
\hline & & $3 / 18 / 03$ & -- & -- & -- & -- \\
\hline & & $4 / 1 / 03$ & $<\mathrm{MDL}$ & $<\mathrm{MDL}$ & $<\mathrm{MDL}$ & $<\mathrm{MDL}$ \\
\hline & & $4 / 15 / 03$ & -- & -- & -- & -- \\
\hline & & $5 / 13 / 03$ & $<\mathrm{MDL}$ & $<\mathrm{MDL}$ & $<\mathrm{MDL}$ & $<\mathrm{MDL}$ \\
\hline & & $5 / 27 / 03$ & -- & -- & -- & -- \\
\hline & & $6 / 17 / 03$ & -- & -- & -- & -- \\
\hline & & 6/30/03 & -- & -- & -- & -- \\
\hline & & 8/19/03 & -- & -- & -- & -- \\
\hline & & $9 / 16 / 03$ & -- & -- & -- & -- \\
\hline & & $10 / 21 / 03$ & -- & -- & -- & -- \\
\hline & & $11 / 11 / 03$ & $<\mathrm{MDL}$ & $<\mathrm{MDL}$ & $<\mathrm{MDL}$ & $<\mathrm{MDL}$ \\
\hline & & $12 / 16 / 03$ & -- & -- & -- & -- \\
\hline & & $1 / 13 / 04$ & -- & -- & -- & -- \\
\hline & & $2 / 10 / 04$ & -- & -- & -- & -- \\
\hline & & $3 / 16 / 04$ & -- & -- & -- & -- \\
\hline \multicolumn{7}{|l|}{ Duplicates } \\
\hline 410322096191701 & $\begin{array}{l}\text { W90-1H } \\
\text { duplicate }\end{array}$ & $3 / 18 / 03$ & $<\mathrm{MDL}$ & $<\mathrm{MDL}$ & $3.8 \mathrm{E}+05$ & $3.8 \mathrm{E}+05$ \\
\hline 410315096190101 & $\begin{array}{l}\text { Raw water } \\
\text { duplicate }\end{array}$ & $5 / 13 / 03$ & $<\mathrm{MDL}$ & $<\mathrm{MDL}$ & $1.1 \mathrm{E}+02$ & $1.1 \mathrm{E}+02$ \\
\hline \multicolumn{7}{|l|}{ Equipment blank } \\
\hline NA & $\begin{array}{l}\text { Equipment } \\
\text { blank }\end{array}$ & $1 / 21 / 03$ & $<\mathrm{MDL}$ & $<\mathrm{MDL}$ & $<\mathrm{MDL}$ & $0.0 \mathrm{E}+00$ \\
\hline
\end{tabular}


Table 9. Microscopic particulate analysis concentrations in samples collected during the riverbank filtration study, Platte River, Nebraska.-Continued

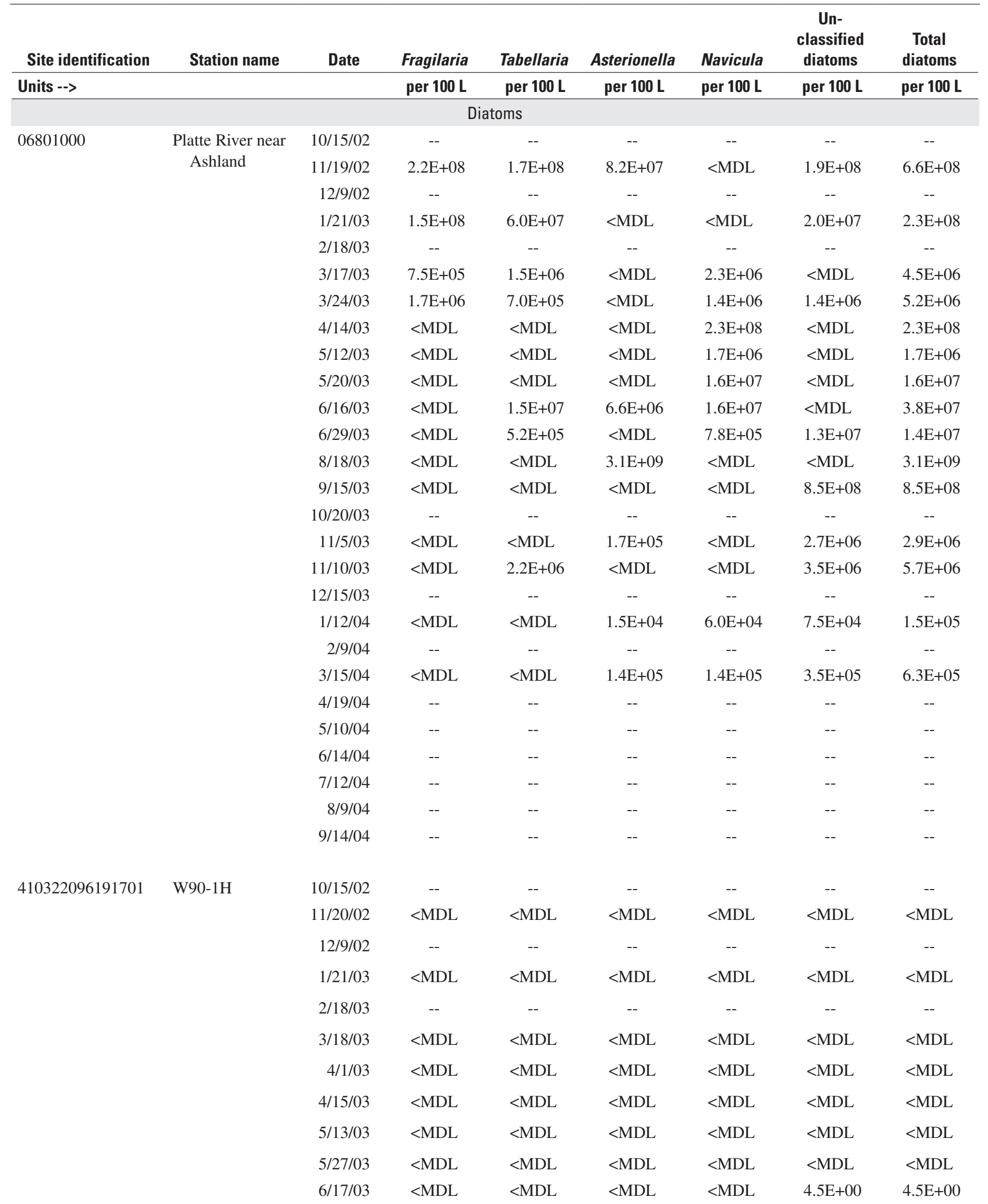




\section{Riverbank Filtration Study, Platte River, Nebraska, 2002 to 2004}

Table 9. Microscopic particulate analysis concentrations in samples collected during the riverbank filtration study, Platte River, Nebraska.-Continued

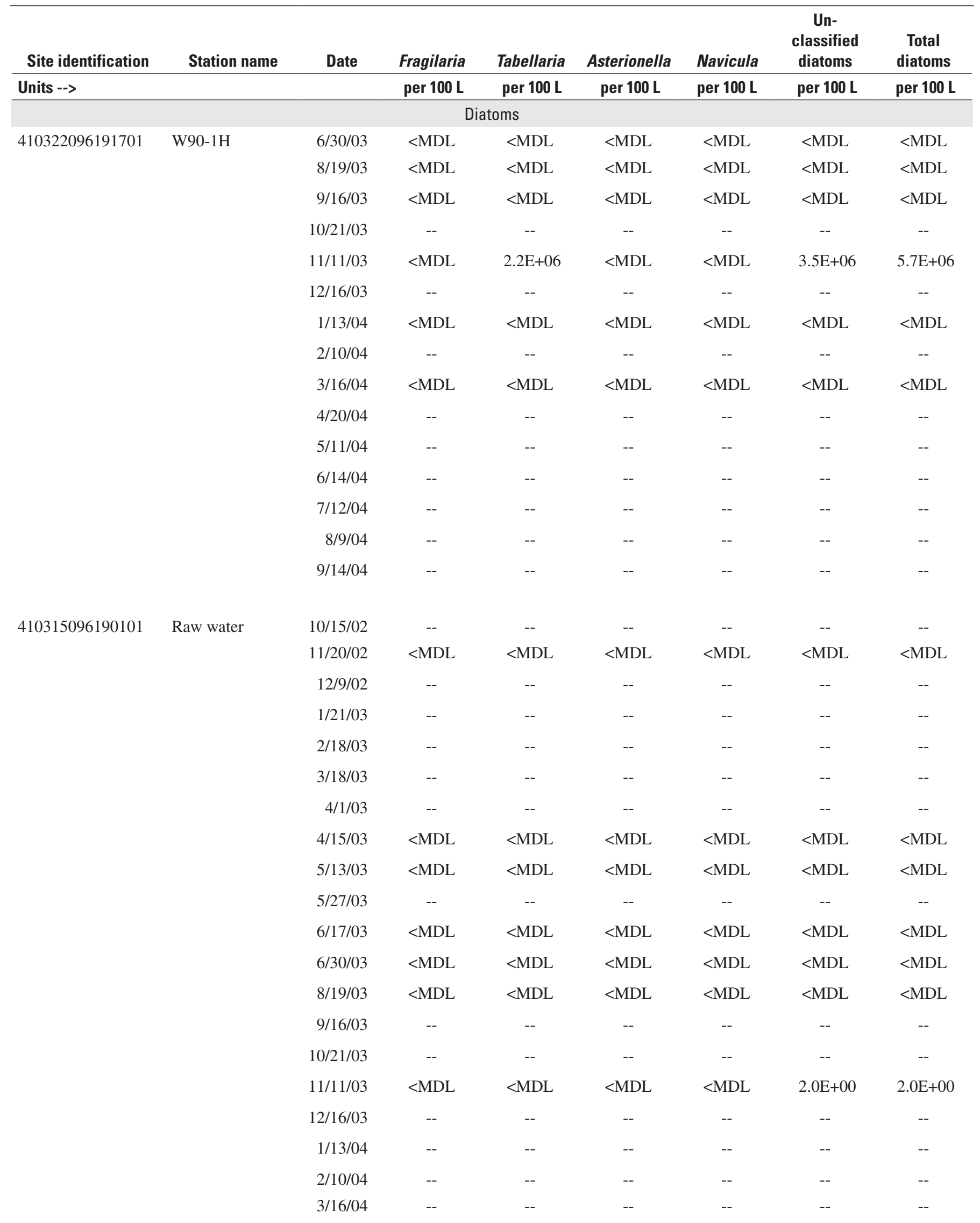


Table 9. Microscopic particulate analysis concentrations in samples collected during the riverbank filtration study, Platte River, Nebraska.-Continued

\begin{tabular}{|c|c|c|c|c|c|c|c|c|}
\hline Site identification & Station name & Date & Fragilaria & Tabellaria & Asterionella & Navicula & $\begin{array}{c}\text { Un- } \\
\text { classified } \\
\text { diatoms }\end{array}$ & $\begin{array}{c}\text { Total } \\
\text { diatoms }\end{array}$ \\
\hline Units --> & & & per $100 \mathrm{~L}$ & per $100 \mathrm{~L}$ & per $100 \mathrm{~L}$ & per $100 \mathrm{~L}$ & per $100 \mathrm{~L}$ & per $100 \mathrm{~L}$ \\
\hline \multicolumn{9}{|c|}{ Diatoms } \\
\hline \multirow[t]{20}{*}{410315096190102} & Finished water & $10 / 15 / 02$ & -- & -- & -- & -- & -- & -- \\
\hline & & $11 / 20 / 02$ & $<\mathrm{MDL}$ & $<\mathrm{MDL}$ & $<\mathrm{MDL}$ & $<\mathrm{MDL}$ & $<\mathrm{MDL}$ & $<\mathrm{MDL}$ \\
\hline & & $12 / 9 / 02$ & -- & -- & -- & -- & -- & -- \\
\hline & & $1 / 21 / 03$ & -- & -- & -- & -- & -- & -- \\
\hline & & $2 / 18 / 03$ & -- & -- & -- & -- & -- & -- \\
\hline & & $3 / 18 / 03$ & -- & -- & -- & -- & -- & -- \\
\hline & & $4 / 1 / 03$ & $<\mathrm{MDL}$ & $<\mathrm{MDL}$ & $<\mathrm{MDL}$ & $<\mathrm{MDL}$ & $<\mathrm{MDL}$ & $<\mathrm{MDL}$ \\
\hline & & $4 / 15 / 03$ & -- & -- & -- & -- & -- & -- \\
\hline & & $5 / 13 / 03$ & $<\mathrm{MDL}$ & $<\mathrm{MDL}$ & $<\mathrm{MDL}$ & $<\mathrm{MDL}$ & $<\mathrm{MDL}$ & $<\mathrm{MDL}$ \\
\hline & & $5 / 27 / 03$ & -- & -- & -- & -- & -- & -- \\
\hline & & $6 / 17 / 03$ & -- & -- & -- & -- & -- & -- \\
\hline & & $6 / 30 / 03$ & -- & -- & -- & -- & -- & -- \\
\hline & & $8 / 19 / 03$ & -- & -- & -- & -- & -- & -- \\
\hline & & $9 / 16 / 03$ & -- & -- & -- & -- & -- & -- \\
\hline & & $10 / 21 / 03$ & -- & -- & -- & -- & -- & -- \\
\hline & & $11 / 11 / 03$ & $<\mathrm{MDL}$ & $<\mathrm{MDL}$ & $<\mathrm{MDL}$ & $<\mathrm{MDL}$ & $<\mathrm{MDL}$ & $<\mathrm{MDL}$ \\
\hline & & $12 / 16 / 03$ & -- & -- & -- & -- & -- & -- \\
\hline & & $1 / 13 / 04$ & -- & -- & -- & -- & -- & -- \\
\hline & & $2 / 10 / 04$ & -- & -- & -- & -- & -- & -- \\
\hline & & $3 / 16 / 04$ & -- & -- & -- & -- & -- & -- \\
\hline \multicolumn{9}{|l|}{ Duplicates } \\
\hline 410322096191701 & $\begin{array}{l}\text { W90-1H } \\
\text { duplicate }\end{array}$ & $3 / 18 / 03$ & $<\mathrm{MDL}$ & $<\mathrm{MDL}$ & $<\mathrm{MDL}$ & $<\mathrm{MDL}$ & $<\mathrm{MDL}$ & $<\mathrm{MDL}$ \\
\hline 410315096190101 & $\begin{array}{l}\text { Raw water } \\
\text { duplicate }\end{array}$ & $5 / 13 / 03$ & $<\mathrm{MDL}$ & $<\mathrm{MDL}$ & $<\mathrm{MDL}$ & $<\mathrm{MDL}$ & $<\mathrm{MDL}$ & $<\mathrm{MDL}$ \\
\hline \multicolumn{9}{|l|}{ Equipment blank } \\
\hline NA & Equipment blank & $1 / 21 / 03$ & $<\mathrm{MDL}$ & $<\mathrm{MDL}$ & $<\mathrm{MDL}$ & $<\mathrm{MDL}$ & $<\mathrm{MDL}$ & $<\mathrm{MDL}$ \\
\hline
\end{tabular}




\section{Riverbank Filtration Study, Platte River, Nebraska, 2002 to 2004}

Table 9. Microscopic particulate analysis concentrations in samples collected during the riverbank filtration study, Platte River, Nebraska.-Continued

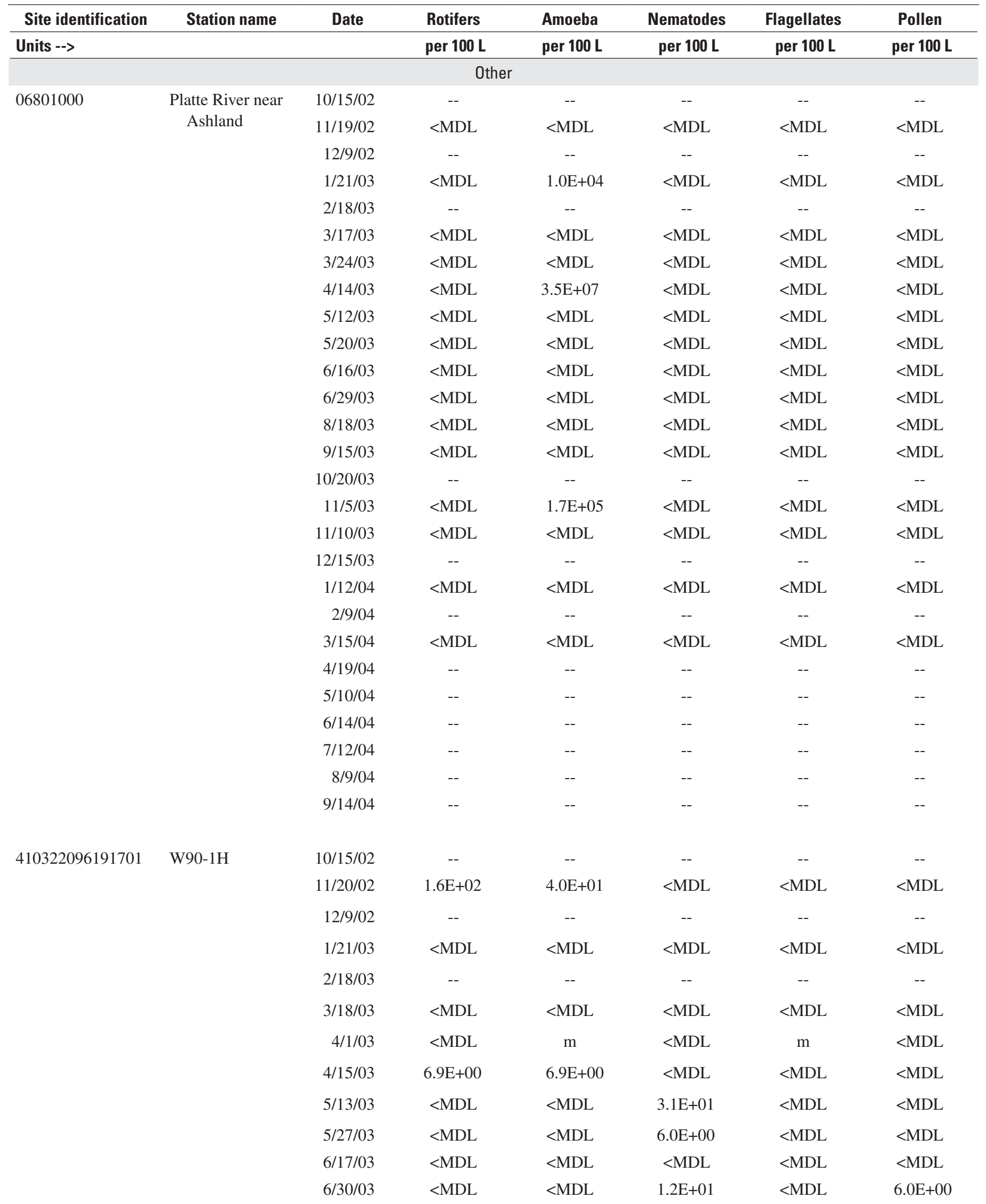


Table 9. Microscopic particulate analysis concentrations in samples collected during the riverbank filtration study, Platte River, Nebraska.-Continued

\begin{tabular}{|c|c|c|c|c|c|c|c|}
\hline Site identification & Station name & Date & Rotifers & Amoeba & Nematodes & Flagellates & Pollen \\
\hline Units --> & & & per $100 \mathrm{~L}$ & per $100 \mathrm{~L}$ & per $100 \mathrm{~L}$ & per $100 \mathrm{~L}$ & per $100 \mathrm{~L}$ \\
\hline \multirow[t]{10}{*}{410322096191701} & W90-1H & $8 / 19 / 03$ & $<\mathrm{MDL}$ & $1.8 \mathrm{E}+01$ & $1.8 \mathrm{E}+01$ & $<\mathrm{MDL}$ & $<\mathrm{MDL}$ \\
\hline & & $10 / 21 / 03$ & -- & -- & -- & -- & -- \\
\hline & & $11 / 11 / 03$ & $<\mathrm{MDL}$ & $<\mathrm{MDL}$ & $<\mathrm{MDL}$ & $<\mathrm{MDL}$ & $<\mathrm{MDL}$ \\
\hline & & $1 / 13 / 04$ & $6.0 \mathrm{E}+00$ & $<\mathrm{MDL}$ & $<\mathrm{MDL}$ & $<\mathrm{MDL}$ & $<\mathrm{MDL}$ \\
\hline & & $2 / 10 / 04$ & -- & -- & -- & -- & -- \\
\hline & & $3 / 16 / 04$ & $<\mathrm{MDL}$ & $<\mathrm{MDL}$ & $<\mathrm{MDL}$ & $<\mathrm{MDL}$ & $<\mathrm{MDL}$ \\
\hline & & $4 / 20 / 04$ & -- & -- & -- & -- & -- \\
\hline & & $7 / 12 / 04$ & -- & -- & -- & -- & -- \\
\hline & & $8 / 9 / 04$ & -- & -- & -- & -- & -- \\
\hline & & $9 / 14 / 04$ & -- & -- & -- & -- & -- \\
\hline \multirow[t]{15}{*}{410315096190101} & Raw water & $10 / 15 / 02$ & -- & -- & -- & -- & -- \\
\hline & & $11 / 20 / 02$ & $1.8 \mathrm{E}+02$ & $6.0 \mathrm{E}+01$ & $3.0 \mathrm{E}+01$ & $3.0 \mathrm{E}+01$ & $<\mathrm{MDL}$ \\
\hline & & $12 / 9 / 02$ & -- & -- & -- & -- & -- \\
\hline & & $1 / 21 / 03$ & -- & -- & -- & -- & -- \\
\hline & & $5 / 27 / 03$ & -- & -- & -- & -- & -- \\
\hline & & $6 / 17 / 03$ & $<\mathrm{MDL}$ & $<\mathrm{MDL}$ & $<\mathrm{MDL}$ & $<\mathrm{MDL}$ & $<\mathrm{MDL}$ \\
\hline & & $6 / 30 / 03$ & $<\mathrm{MDL}$ & $<\mathrm{MDL}$ & $<\mathrm{MDL}$ & $<\mathrm{MDL}$ & $<\mathrm{MDL}$ \\
\hline & & 8/19/03 & $<\mathrm{MDL}$ & $<\mathrm{MDL}$ & $1.6 \mathrm{E}+01$ & $<\mathrm{MDL}$ & $3.0 \mathrm{E}+00$ \\
\hline & & $9 / 16 / 03$ & -- & -- & -- & -- & -- \\
\hline & & $10 / 21 / 03$ & -- & -- & -- & -- & -- \\
\hline & & $11 / 11 / 03$ & $2.0 \mathrm{E}+00$ & $<\mathrm{MDL}$ & $6.0 \mathrm{E}+00$ & $<\mathrm{MDL}$ & $<\mathrm{MDL}$ \\
\hline & & $12 / 16 / 03$ & -- & -- & -- & -- & -- \\
\hline & & $1 / 13 / 04$ & -- & -- & -- & -- & -- \\
\hline & & $2 / 10 / 04$ & -- & -- & -- & -- & -- \\
\hline & & $3 / 16 / 04$ & -- & -- & -- & -- & -- \\
\hline
\end{tabular}


Table 9. Microscopic particulate analysis concentrations in samples collected during the riverbank filtration study, Platte River, Nebraska.-Continued

\begin{tabular}{|c|c|c|c|c|c|c|c|}
\hline Site identification & Station name & Date & Rotifers & Amoeba & Nematodes & Flagellates & Pollen \\
\hline Units --> & & & per $100 \mathrm{~L}$ & per $100 \mathrm{~L}$ & per $100 \mathrm{~L}$ & per $100 \mathrm{~L}$ & per $100 \mathrm{~L}$ \\
\hline \multirow[t]{15}{*}{410315096190102} & Finished water & $10 / 15 / 02$ & -- & -- & -- & -- & -- \\
\hline & & $12 / 9 / 02$ & -- & -- & -- & -- & -- \\
\hline & & $1 / 21 / 03$ & -- & -- & -- & -- & -- \\
\hline & & $3 / 18 / 03$ & -- & -- & -- & -- & -- \\
\hline & & $4 / 1 / 03$ & $<\mathrm{MDL}$ & $<\mathrm{MDL}$ & $<\mathrm{MDL}$ & $<\mathrm{MDL}$ & $<\mathrm{MDL}$ \\
\hline & & $4 / 15 / 03$ & -- & -- & -- & -- & -- \\
\hline & & $5 / 13 / 03$ & $<\mathrm{MDL}$ & $<\mathrm{MDL}$ & $<\mathrm{MDL}$ & $<\mathrm{MDL}$ & $<\mathrm{MDL}$ \\
\hline & & $6 / 30 / 03$ & -- & -- & -- & -- & -- \\
\hline & & $8 / 19 / 03$ & -- & -- & -- & -- & -- \\
\hline & & $9 / 16 / 03$ & -- & -- & -- & -- & -- \\
\hline & & $10 / 21 / 03$ & -- & -- & -- & -- & -- \\
\hline & & $11 / 11 / 03$ & $<\mathrm{MDL}$ & $<\mathrm{MDL}$ & $<\mathrm{MDL}$ & $<\mathrm{MDL}$ & $<\mathrm{MDL}$ \\
\hline & & $12 / 16 / 03$ & -- & -- & -- & -- & -- \\
\hline & & $1 / 13 / 04$ & -- & -- & -- & -- & -- \\
\hline & & $2 / 10 / 04$ & -- & -- & -- & -- & -- \\
\hline 410315096190101 & $\begin{array}{l}\text { Raw water } \\
\text { duplicate }\end{array}$ & $5 / 13 / 03$ & $1.6 \mathrm{E}+02$ & $<\mathrm{MDL}$ & $3.0 \mathrm{E}+01$ & $<\mathrm{MDL}$ & $<\mathrm{MDL}$ \\
\hline \multicolumn{8}{|l|}{ Equipment blank } \\
\hline NA & Equipment blank & $1 / 21 / 03$ & $<\mathrm{MDL}$ & $<\mathrm{MDL}$ & $<\mathrm{MDL}$ & $<\mathrm{MDL}$ & $<\mathrm{MDL}$ \\
\hline
\end{tabular}


Table 9. Microscopic particulate analysis concentrations in samples collected during the riverbank filtration study, Platte River, Nebraska.-Continued

\begin{tabular}{|c|c|c|c|}
\hline Site identification & Station name & Date & Comments \\
\hline \multirow[t]{19}{*}{06801000} & Platte River near & $10 / 15 / 02$ & - \\
\hline & Ashland & $11 / 19 / 02$ & No other bioindicators indicated \\
\hline & & $1 / 21 / 03$ & Unclassified algae were coccoid \\
\hline & & $2 / 18 / 03$ & - \\
\hline & & $3 / 24 / 03$ & $\begin{array}{l}\text { Unclassified algea were coccoid green algae; large number of non-intact diatoms } \\
\text { were present, but not counted as they didn't meet the criteria. }\end{array}$ \\
\hline & & $4 / 14 / 03$ & Unclassified algae were coccoid; no other bioindicators indicated \\
\hline & & $5 / 12 / 03$ & $\begin{array}{l}\text { Unclassified algae were coccoid; large amounts of fine and coarse amorphous } \\
\text { debris present }\end{array}$ \\
\hline & & $6 / 29 / 03$ & $\begin{array}{l}\text { Unclassifed algae were coccoid; large amounts of fine and coarse amorphous } \\
\text { debris present }\end{array}$ \\
\hline & & $8 / 18 / 03$ & $\begin{array}{l}\text { Unclassifed algae were coccoid; large amounts of fine and coarse amorphous } \\
\text { debris present }\end{array}$ \\
\hline & & $9 / 15 / 03$ & $\begin{array}{l}\text { Unclassifed algae were coccoid; large amounts of fine and coarse amorphous } \\
\text { debris present }\end{array}$ \\
\hline & & $10 / 20 / 03$ & - \\
\hline & & $11 / 5 / 03$ & $\begin{array}{l}\text { Unclassified algae were coccoid; large amounts of fine and coarse amorphous } \\
\text { debris present }\end{array}$ \\
\hline & & $3 / 15 / 04$ & $\begin{array}{l}\text { Unclassifed algae were coccoid; large amounts of fine and coarse amorphous } \\
\text { debris present }\end{array}$ \\
\hline & & $4 / 19 / 04$ & - \\
\hline & & $5 / 10 / 04$ & - \\
\hline & & $6 / 14 / 04$ & - \\
\hline & & $7 / 12 / 04$ & - \\
\hline & & $8 / 9 / 04$ & - \\
\hline & & $9 / 14 / 04$ & - \\
\hline \multirow[t]{5}{*}{410322096191701} & W90-1H & $10 / 15 / 02$ & - \\
\hline & & $11 / 20 / 02$ & No other bioindicators were identified \\
\hline & & $12 / 9 / 02$ & - \\
\hline & & $1 / 21 / 03$ & Iron-related bacteria were present in high numbers \\
\hline & & $2 / 18 / 03$ & - \\
\hline
\end{tabular}




\section{Riverbank Filtration Study, Platte River, Nebraska, 2002 to 2004}

Table 9. Microscopic particulate analysis concentrations in samples collected during the riverbank filtration study, Platte River, Nebraska.-Continued

\begin{tabular}{|c|c|c|c|}
\hline Site identification & Station name & Date & Comments \\
\hline \multirow[t]{12}{*}{410322096191701} & W90-1H & $3 / 18 / 03$ & Unclassified algae were green coccoid; large amounts of iron present \\
\hline & & $4 / 1 / 03$ & Iron debris was present \\
\hline & & $5 / 13 / 03$ & Unclassified algae were coccoid \\
\hline & & $5 / 27 / 03$ & Unclassified algae were coccoid \\
\hline & & $6 / 30 / 03$ & $\begin{array}{l}\text { Unclassified algae were coccoid; plant pollen is pine; large amounts of fine and } \\
\text { coarse amorphous debris present }\end{array}$ \\
\hline & & $8 / 19 / 03$ & $\begin{array}{l}\text { Large number of non-intact diatoms were present, but not counted as they didn't } \\
\text { meet the criteria. }\end{array}$ \\
\hline & & $11 / 11 / 03$ & $\begin{array}{l}\text { Large amounts of fine and coarse amorphous debris were present; filamentous } \\
\text { (sulfur/iron) bacteria present in large numbers; no bioindicators detected }\end{array}$ \\
\hline & & $12 / 16 / 03$ & - \\
\hline & & $1 / 13 / 04$ & $\begin{array}{l}\text { Unclassified algae were coccoid; large amounts of amorphous debris present and } \\
\text { ferric minerals; many undeveloped/hibernating rotifers }\end{array}$ \\
\hline & & $2 / 10 / 04$ & - \\
\hline & & $3 / 16 / 04$ & $\begin{array}{l}\text { Unclassified algae are coccoid; large amounts of amorphous debris present and } \\
\text { ferric minerals }\end{array}$ \\
\hline & & $4 / 20 / 04$ & - \\
\hline \multirow[t]{11}{*}{410315096190101} & Raw water & $10 / 15 / 02$ & - \\
\hline & & $11 / 20 / 02$ & $\begin{array}{l}\text { Unclassified algae were coccoid green algae }(6-8 \mathrm{~mm}) \text {; high number of iron- } \\
\text { related bacteria and iron debris were present }\end{array}$ \\
\hline & & $12 / 9 / 02$ & - \\
\hline & & $1 / 21 / 03$ & - \\
\hline & & $2 / 18 / 03$ & - \\
\hline & & $3 / 18 / 03$ & - \\
\hline & & $4 / 1 / 03$ & - \\
\hline & & $4 / 15 / 03$ & Unclassified algae were coccoid; iron debris present in low levels \\
\hline & & $5 / 13 / 03$ & Unclassified algae were green coccoid; iron debris was present at low levels \\
\hline & & $5 / 27 / 03$ & - \\
\hline & & $6 / 17 / 03$ & $\begin{array}{l}\text { Large amounts of iron debris, dead filamentous algae and sulfate-reducing } \\
\text { bacteria; no bioindicators detected }\end{array}$ \\
\hline
\end{tabular}


Table 9. Microscopic particulate analysis concentrations in samples collected during the riverbank filtration study, Platte River, Nebraska.-Continued

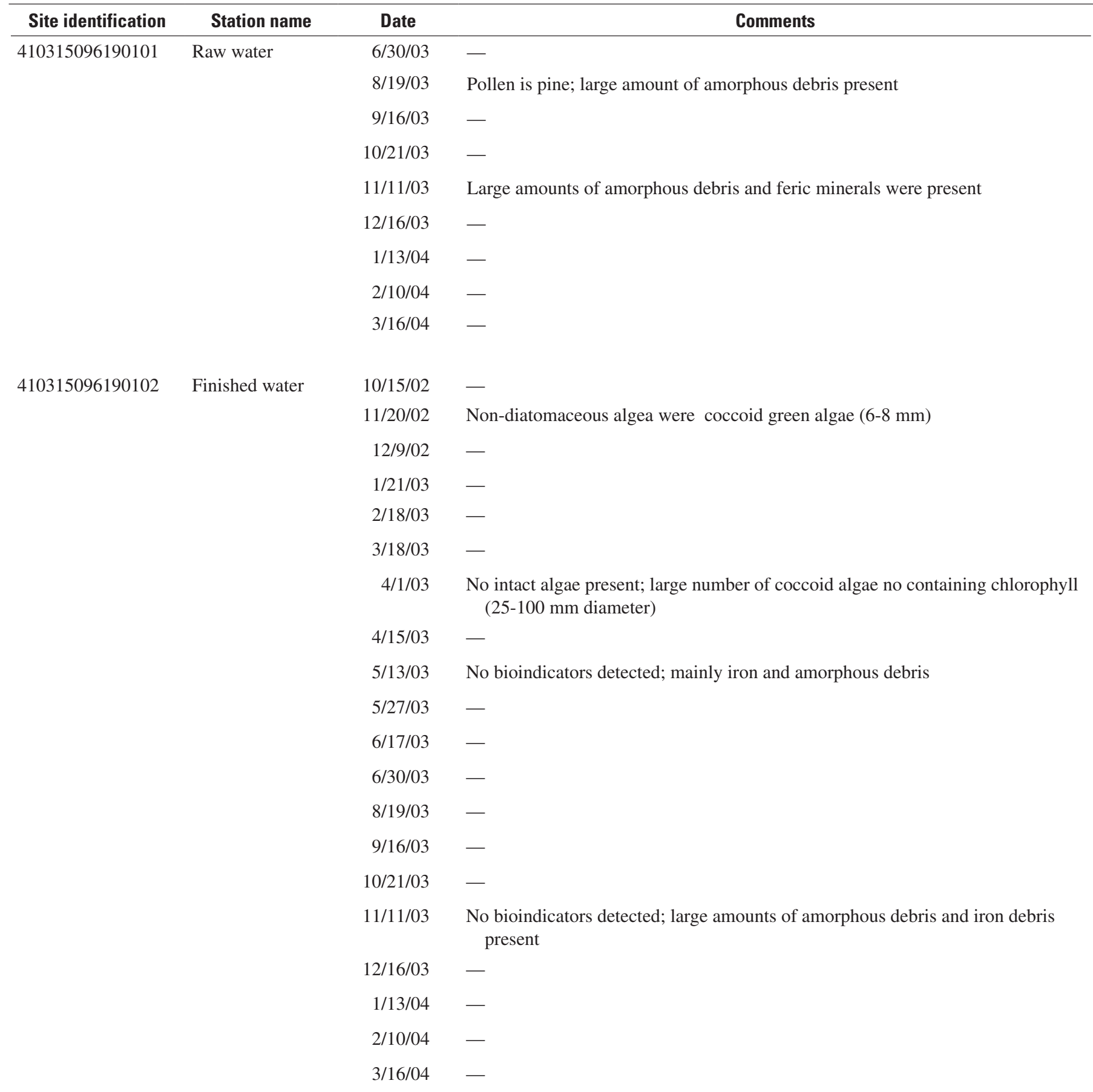

\section{Duplicates}

$\begin{array}{cccc}410322096191701 & \begin{array}{c}\text { W90-1H } \\ \text { duplicate }\end{array} & 3 / 18 / 03 & \text { No other bioindicators detected; no iron particulates present } \\ 410315096190101 & \begin{array}{c}\text { Raw water } \\ \text { duplicate }\end{array} & 5 / 13 / 03 & \text { Unclassified algae were coccoid; Iron debris present in low levels }\end{array}$

Equipment blank

NA 
Table 10. Summary statistics of laser particle counts in samples collected during riverbank filtration study, Platte River, Nebraska.

[Units are counts per 100 milliliters; n, number of samples; med, median; max, maximum; std. dev. , standard deviation; $\mu$ m, micrometers; na, not applicable; $>$, greater than; M, one or more samples measured but not quantified, these samples not included in summary statistics; $x . x$ eyy, x.x times 10 raised to the yy power, for example, $1.8 \mathrm{e} 08$ is 1.8 times $10^{8}$ ]

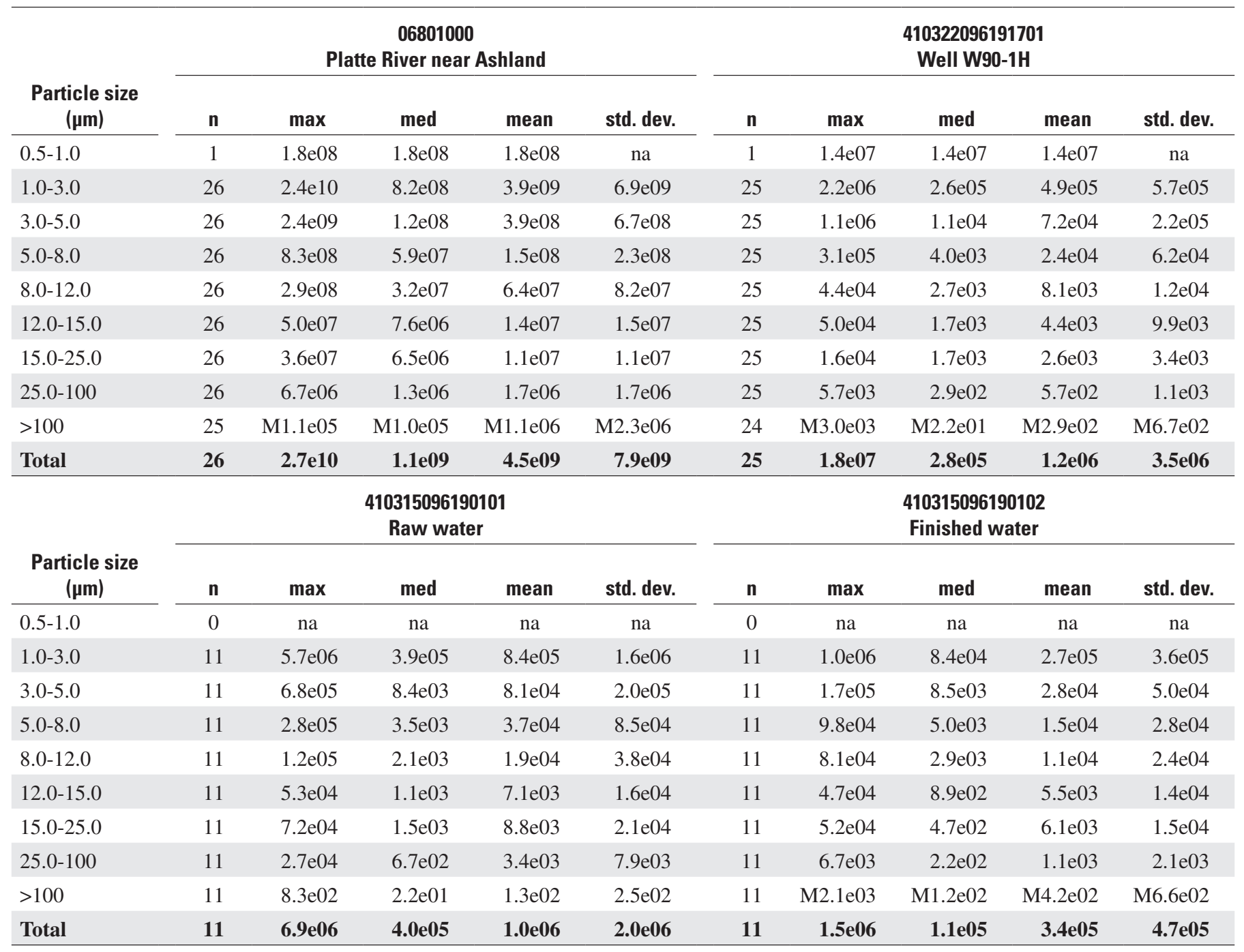




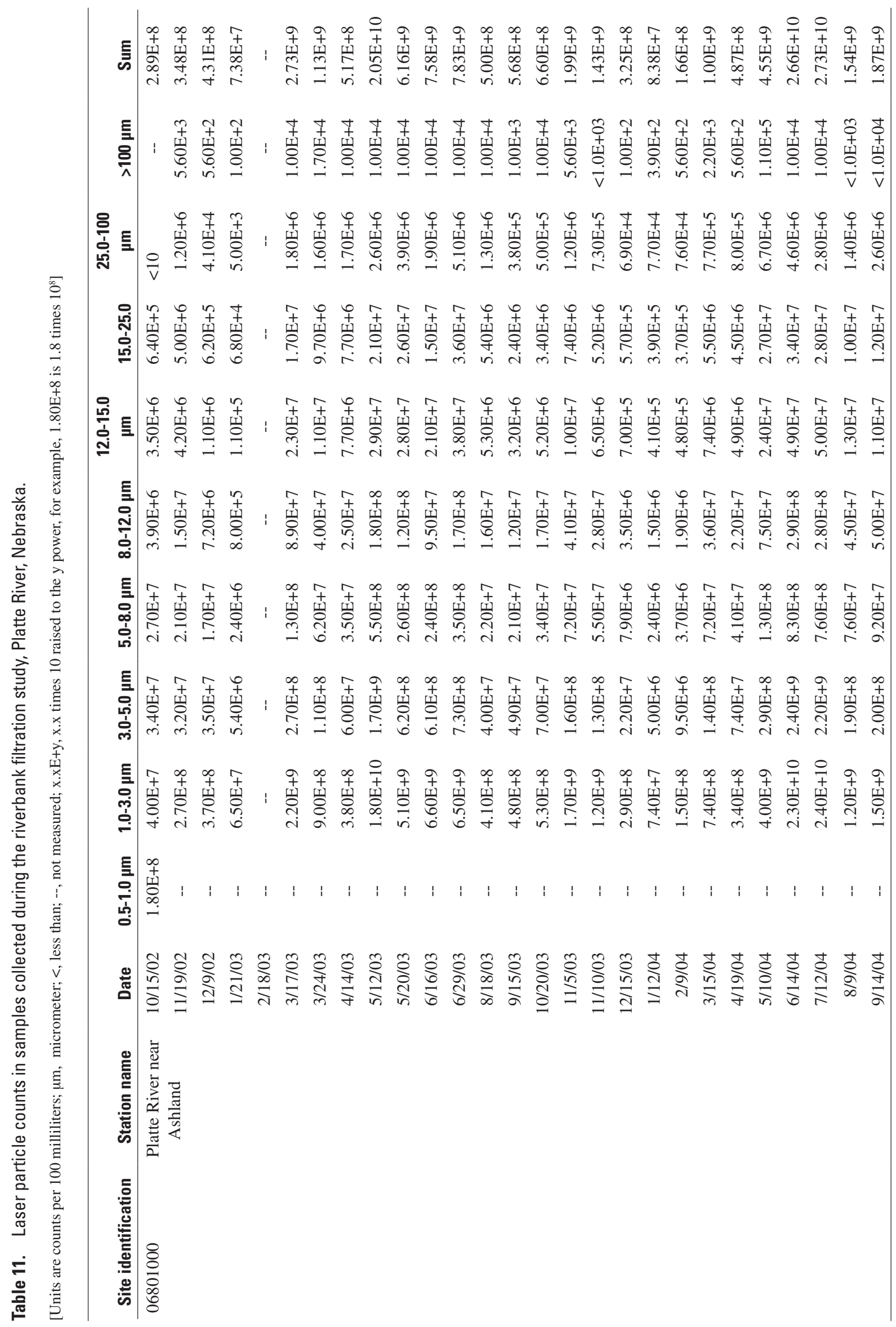




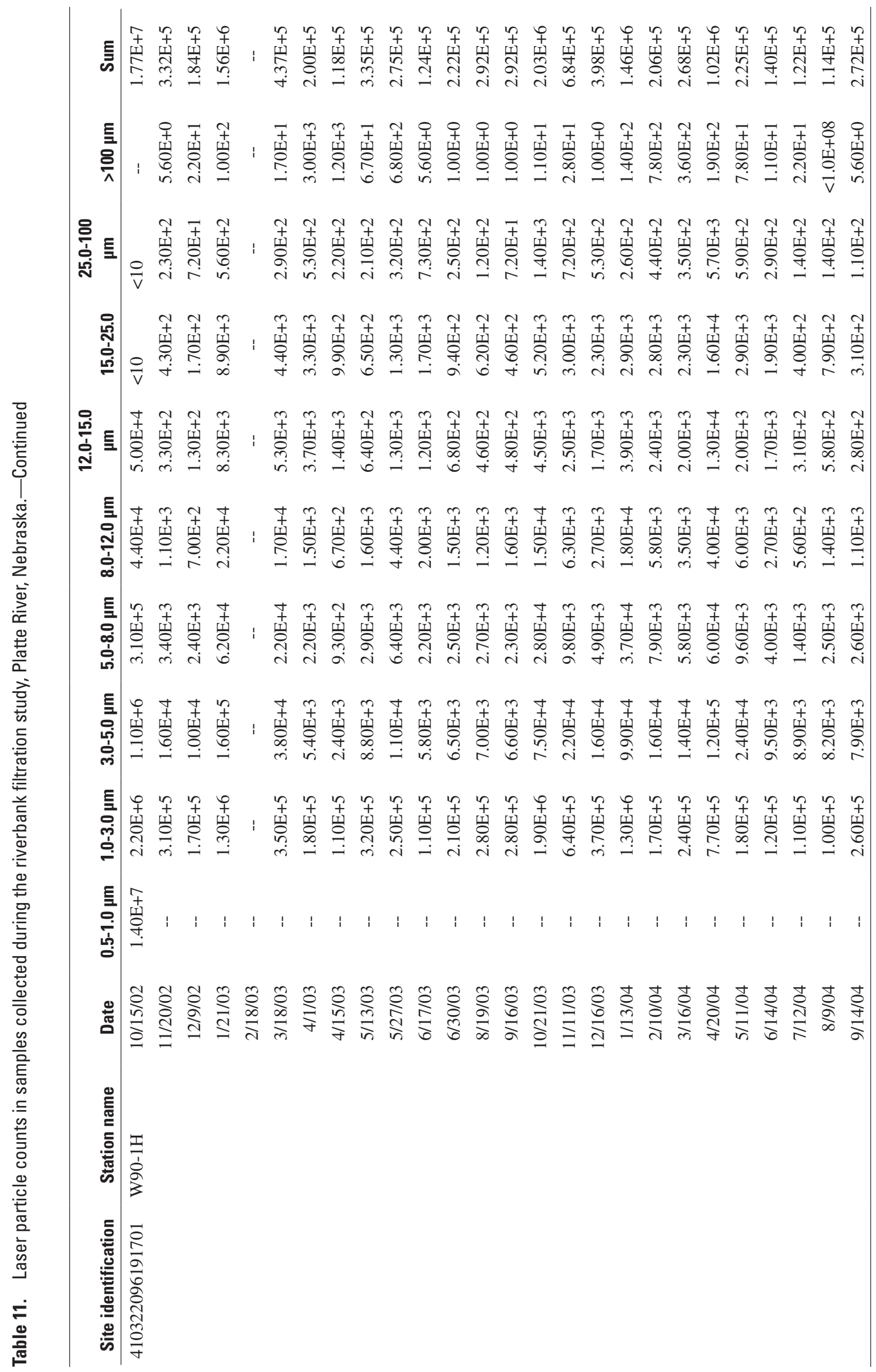




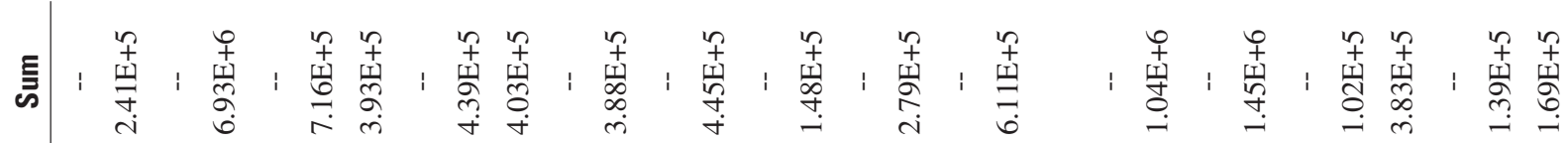

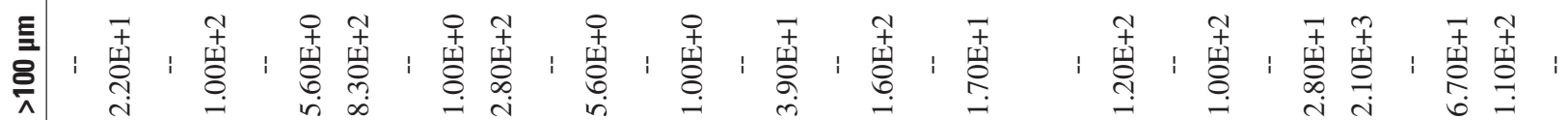

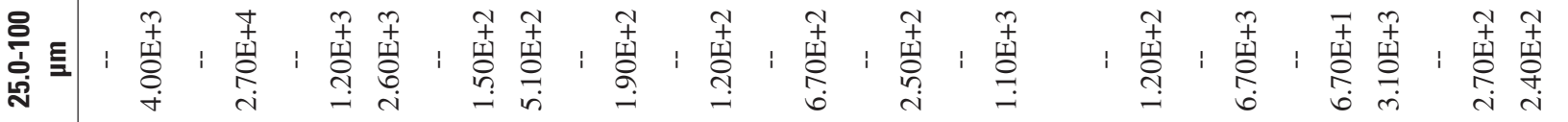

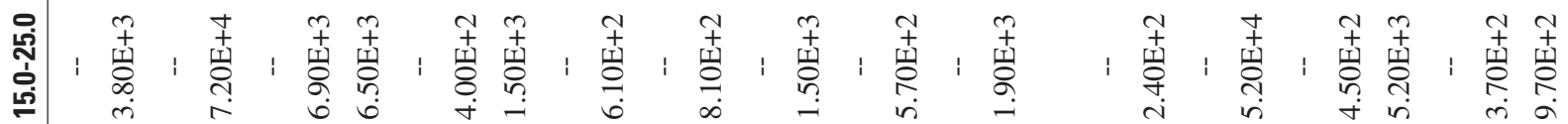

皇

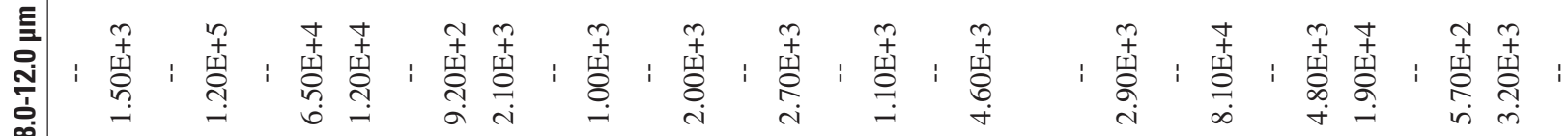

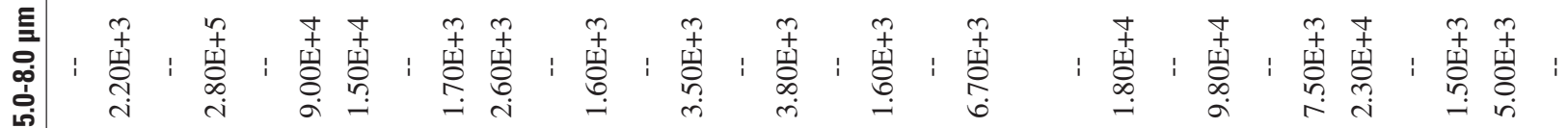

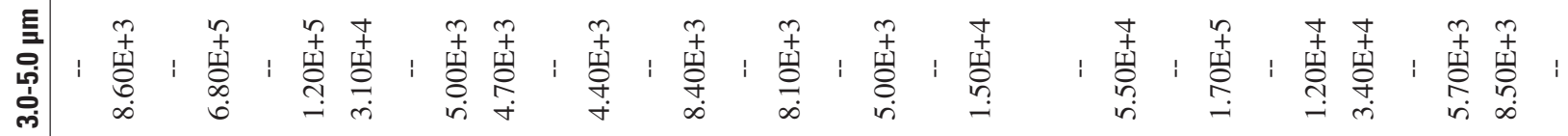

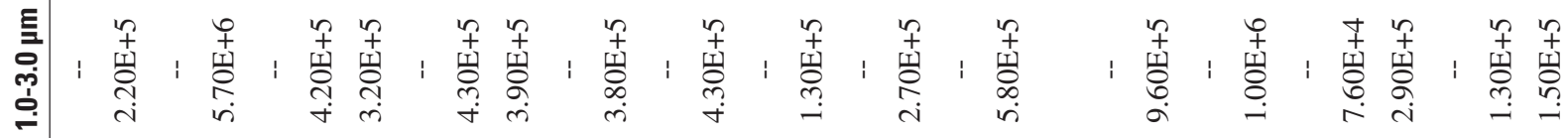

恶

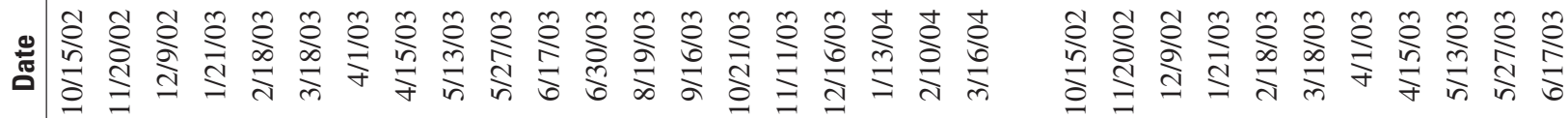




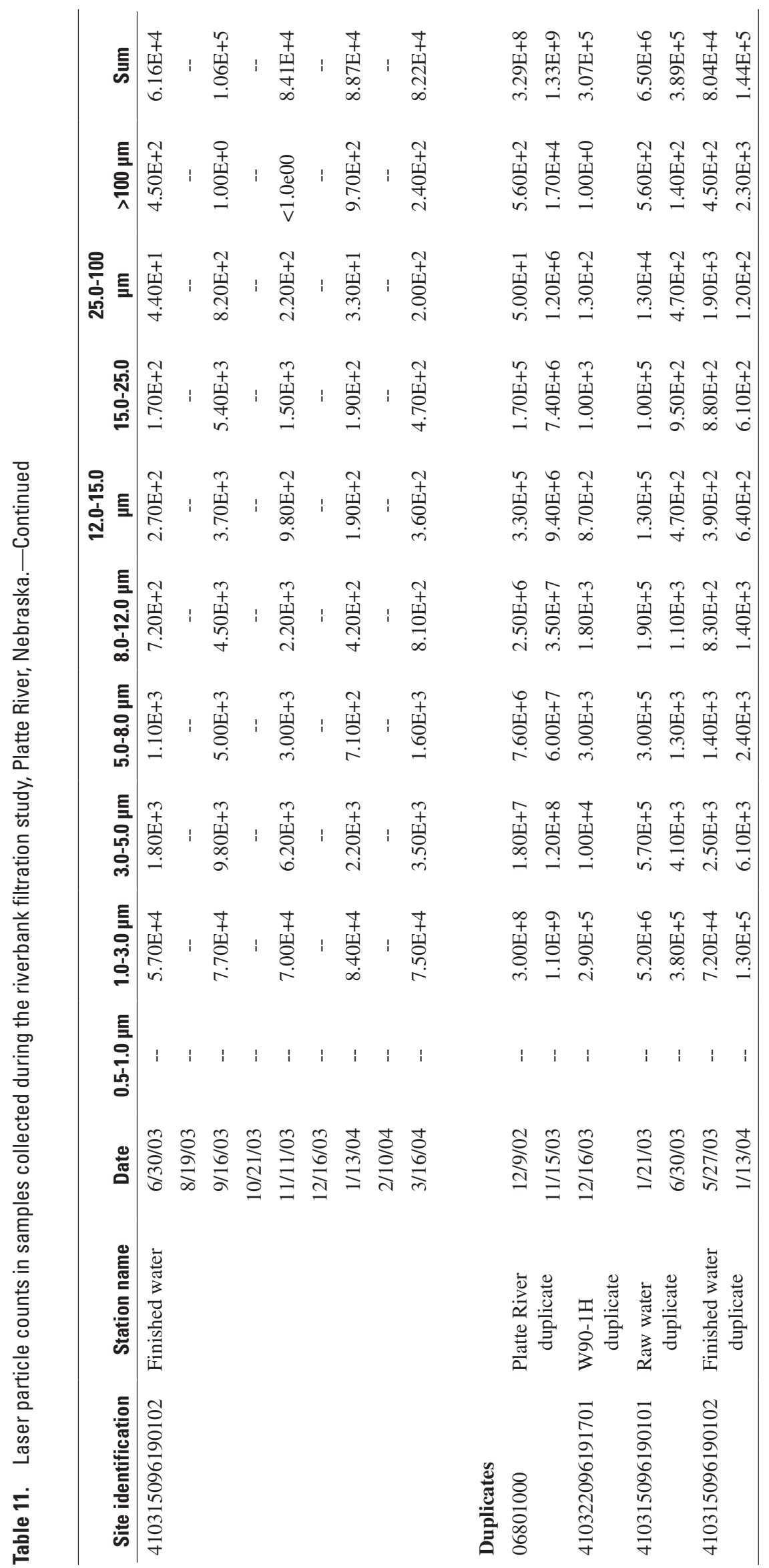




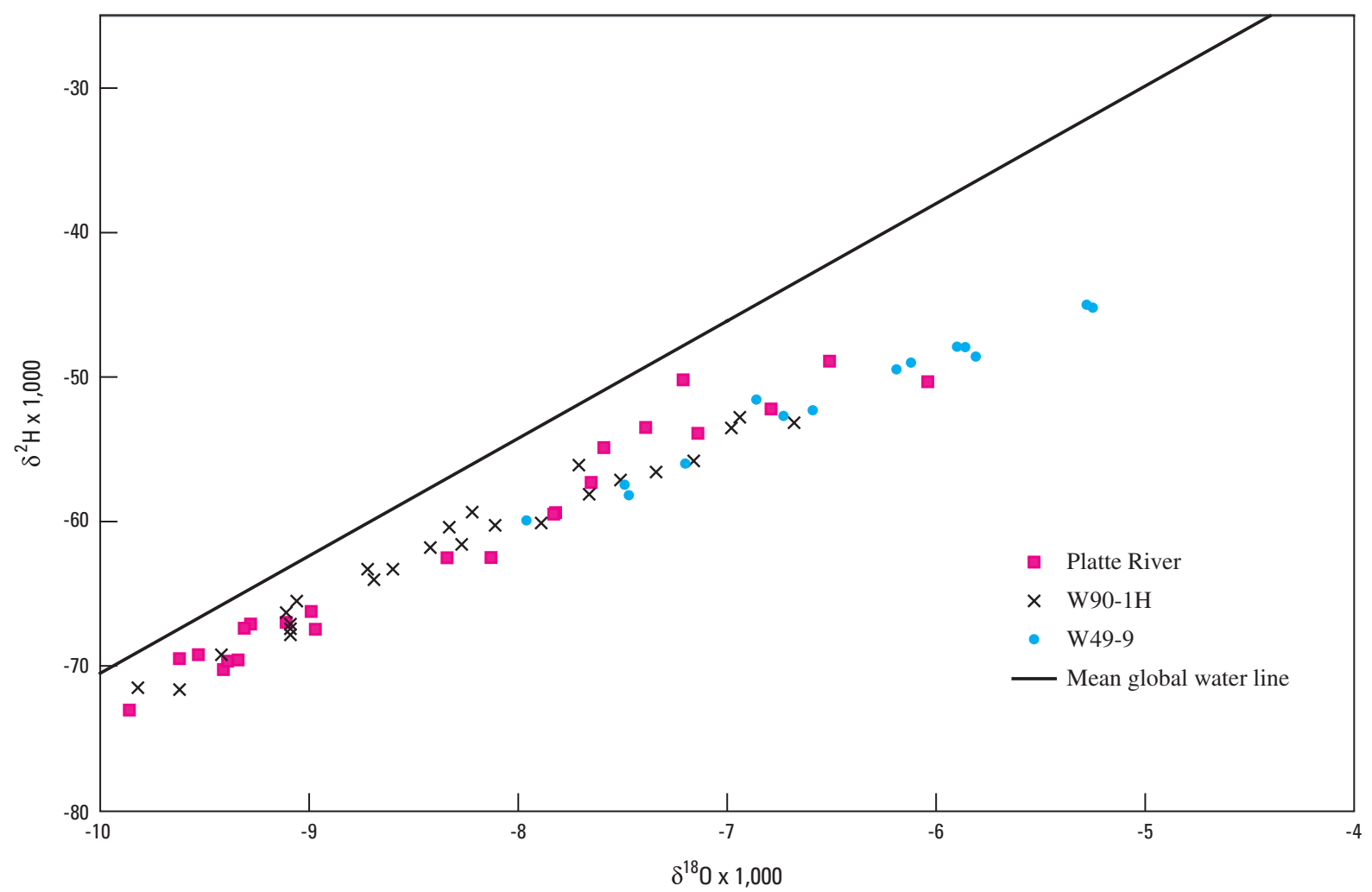

Figure 8. Stable hydrogen and oxygen isotope ratios in samples from the Platte River and the well field during the riverbank filtration study, Platte River, Nebraska. 
Table 12. Stable hydrogen and oxygen isotope ratios in samples collected during the riverbank filtration study, Platte River, Nebraska.

[per mill; per thousand; --, not measured]

\begin{tabular}{|c|c|c|c|c|}
\hline Site identification & Station name & Date & $\begin{array}{l}\text { Hydrogen ratio } \\
\text { (per mill) }\end{array}$ & $\begin{array}{l}\text { Oxygen ratio } \\
\text { (per mill) }\end{array}$ \\
\hline \multirow[t]{27}{*}{06801000} & \multirow[t]{27}{*}{ Platte River near Ashland } & $10 / 15 / 02$ & -59.4 & -7.82 \\
\hline & & $11 / 19 / 02$ & -67.0 & -9.11 \\
\hline & & $12 / 9 / 02$ & -70.3 & -9.41 \\
\hline & & $1 / 21 / 03$ & -69.6 & -9.34 \\
\hline & & $2 / 18 / 03$ & -73.1 & -9.86 \\
\hline & & $3 / 17 / 03$ & -69.7 & -9.39 \\
\hline & & $3 / 24 / 03$ & -67.5 & -8.97 \\
\hline & & $4 / 14 / 03$ & -62.5 & -8.34 \\
\hline & & $5 / 12 / 03$ & -54.9 & -7.59 \\
\hline & & $5 / 20 / 03$ & -57.3 & -7.65 \\
\hline & & $6 / 16 / 03$ & -62.5 & -8.13 \\
\hline & & $6 / 29 / 03$ & -52.2 & -6.79 \\
\hline & & $8 / 18 / 03$ & -50.3 & -6.04 \\
\hline & & $9 / 15 / 03$ & broken sample & broken sample \\
\hline & & $10 / 20 / 03$ & broken sample & broken sample \\
\hline & & $11 / 5 / 03$ & broken sample & broken sample \\
\hline & & $11 / 10 / 03$ & -66.2 & -8.99 \\
\hline & & $12 / 15 / 03$ & -69.2 & -9.53 \\
\hline & & $1 / 12 / 04$ & -67.1 & -9.28 \\
\hline & & $2 / 9 / 04$ & -69.5 & -9.62 \\
\hline & & $3 / 15 / 04$ & -67.4 & -9.31 \\
\hline & & $4 / 19 / 04$ & -59.5 & -7.83 \\
\hline & & $5 / 10 / 04$ & -53.9 & -7.14 \\
\hline & & $6 / 14 / 04$ & -53.5 & -7.39 \\
\hline & & $7 / 12 / 04$ & -50.2 & -7.21 \\
\hline & & $8 / 9 / 04$ & -48.9 & -6.51 \\
\hline & & $9 / 14 / 04$ & -48.7 & -6.09 \\
\hline \multirow[t]{10}{*}{410322096191701} & \multirow[t]{10}{*}{ W90-1H } & $10 / 15 / 02$ & -52.8 & -6.94 \\
\hline & & $11 / 20 / 02$ & -57.1 & -7.51 \\
\hline & & $12 / 9 / 02$ & -60.1 & -7.89 \\
\hline & & $1 / 21 / 03$ & -64.0 & -8.69 \\
\hline & & $2 / 18 / 03$ & -67.1 & -9.09 \\
\hline & & $3 / 18 / 03$ & -71.6 & -9.62 \\
\hline & & $4 / 1 / 03$ & -69.2 & -9.42 \\
\hline & & $4 / 15 / 03$ & -67.4 & -9.09 \\
\hline & & $5 / 13 / 03$ & -67.8 & -9.09 \\
\hline & & $5 / 27 / 03$ & -59.4 & -8.22 \\
\hline
\end{tabular}


Table 12. Stable hydrogen and oxygen isotope ratios in samples collected during the riverbank filtration study, Platte River, Nebraska.-Continued

\begin{tabular}{|c|c|c|c|c|}
\hline Site identification & Station name & Date & $\begin{array}{l}\text { Hydrogen ratio } \\
\text { (per mill) }\end{array}$ & $\begin{array}{c}\text { Oxygen ratio } \\
\text { (per mill) }\end{array}$ \\
\hline \multirow[t]{16}{*}{410322096191701} & W90-1H & $6 / 17 / 03$ & -61.6 & -8.27 \\
\hline & & $6 / 30 / 03$ & -60.3 & -8.11 \\
\hline & & $8 / 19 / 03$ & -53.5 & -6.98 \\
\hline & & $9 / 16 / 03$ & -53.2 & -6.68 \\
\hline & & $10 / 21 / 03$ & -56.6 & -7.34 \\
\hline & & $11 / 11 / 03$ & -55.8 & -7.16 \\
\hline & & $12 / 16 / 03$ & -58.1 & -7.66 \\
\hline & & $1 / 13 / 04$ & -61.8 & -8.42 \\
\hline & & $2 / 10 / 04$ & -65.5 & -9.06 \\
\hline & & $3 / 16 / 04$ & -71.5 & -9.82 \\
\hline & & $4 / 20 / 04$ & -66.3 & -9.11 \\
\hline & & $5 / 11 / 04$ & -63.3 & -8.72 \\
\hline & & $6 / 14 / 04$ & -63.3 & -8.60 \\
\hline & & $7 / 12 / 04$ & -60.4 & -8.33 \\
\hline & & $8 / 9 / 04$ & -56.1 & -7.71 \\
\hline & & $9 / 14 / 04$ & -54.0 & -7.06 \\
\hline \multirow[t]{16}{*}{410349096202101} & W49-9 & $6 / 17 / 03$ & -48.6 & -5.81 \\
\hline & & $6 / 30 / 03$ & -47.9 & -5.86 \\
\hline & & $8 / 19 / 03$ & -49.5 & -6.19 \\
\hline & & $9 / 16 / 03$ & -51.6 & -6.86 \\
\hline & & $10 / 21 / 03$ & -57.5 & -7.49 \\
\hline & & $11 / 12 / 03$ & -59.9 & -7.96 \\
\hline & & $12 / 16 / 03$ & -58.2 & -7.47 \\
\hline & & $1 / 13 / 04$ & -56.0 & -7.20 \\
\hline & & $2 / 10 / 04$ & -52.3 & -6.59 \\
\hline & & $3 / 16 / 04$ & -52.7 & -6.73 \\
\hline & & $4 / 20 / 04$ & -47.9 & -5.90 \\
\hline & & $5 / 11 / 04$ & -49.0 & -6.12 \\
\hline & & $6 / 14 / 04$ & -- & -- \\
\hline & & $7 / 12 / 04$ & -45.0 & -5.28 \\
\hline & & $8 / 9 / 04$ & -45.2 & -5.25 \\
\hline & & $9 / 14 / 04$ & -51.4 & -6.35 \\
\hline
\end{tabular}




\section{References}

Aboytes, Ramon, Di Giovanni, G.D., Abrams, F.A., Rheinecker, Corey, McElroy, Wyndi, Shaw, Nancy, and LeChevallier, M.W., 2004, Detection of infectious Cryptosporidium in filtered drinking water: Journal of the American Water Works Association, v. 96, no. 9, p. 88-98.

Akin, E.W, and Jakubowski, Walter, 1986, Drinking water transmission of giardiasis in the United States: Water Science and Technology, v. 18, no. 10, p. 219-226.

Alm, E.W., Burke, Janice, and Spain, Anne, 2003, Fecal indicator bacteria are abundant in wet sand at freshwater beaches: Water Research, v. 37, no. 16, p. 3978-3982.

Arrowood, M.J., 1997, Diagnosis, in Fayer, Ronald (ed.), Cryptosporidium and Cryptosporidiosis: Boca Raton, Fla., CRC Press LLC, p. 43-64.

Baxter-Potter, W.R., and Gilliland, M.W., 1988, Bacterial pollution in runoff from agricultural lands: Journal of Environmental Quality, v. 17, no. 1, p. 27-34.

Berk, S.G., and Gunderson, J.H., 1993, Wastewater organisms-A color atlas: Boca Raton, Fla., Lewis Publishers, 25 p., 210 figs.

Borst, Michael, and Selvakumar, Ariamalar, 2003, Particleassociated microorganisms in stormwater runoff: Water Research, v. 37, no. 1, p. 215-223.

Boyer, D.G., and Kuczynska, Eva, 2003, Storm and seasonal distributions of fecal coliforms and Cryptosporidium in a spring: Journal of the American Water Resources Association, v. 39, no. 6, p. 1449-1456.

Brenton, R.W., and Arnett, T.L., 1993, Methods of analysis by the U.S. Geological Survey National Water Quality Laboratory-Determination of dissolved organic carbon by UVpromoted persulfate oxidation and infrared spectrometry: U. S. Geological Survey Open-File Report 92-0480, 12 p.

Chauret, C.P., Radziminski, C.Z., Lepuil, Michael, Creason, Robin, and Andrews, R.C., 2001, Chlorine dioxide inactivation of Cryptosporidium parvum oocysts and bacterial spore indicators: Applied and Environmental Microbiology, v. 67, no. 7, p. 2993-3001.

Chauret, Christian, Springthorpe, Susan, and Sattar, Syed, 1999, Fate of Cryptosporidium oocysts, Giardia cysts, and microbial indicators during wastewater treatment and anaerobic sludge digestion: Canadian Journal of Microbiology, v. 45 , no. 3 , p. $257-262$.
Christensen, V.G., Rasmussen, P.P, and Ziegler, A.C., 2001, Real-time water-quality monitoring and regression analysis to estimate nutrient and bacteria concentrations in Kansas streams: U.S. Geological Survey, online report, accessed April 22, 2005, at http://ks.water.usgs.gov/Kansas/pubs/ reports/vgc.0610.html

Chin, D.A., and Qi, Xing, 2000, Ground water under direct influence of surface water: Journal of Environmental Engineering-American Society of Civil Engineers, v. 126, no. 6, p. 501-508.

Cohen, Judith, and Shuval, H.I., 1973, Coliforms, fecal coliforms and fecal streptococci as indicators of water pollution: Water, Air, and Soil Pollution, v. 2, no. 1, p. 85.

Coplen, T.B., 1996, New guidelines for the reporting of stable hydrogen, carbon, and oxygen isotope ratio data: Geochemica et Cosmochimica Acta, v. 60, p. 3359.

Coplen, T.B., Wildman, J.D., and Chen, Julie, 1991. Improvements in the gaseous hydrogen-water equilibration technique for hydrogen isotope ratio analysis: Analytical Chemistry, v. 63, p. 910-912.

Craik, S.A., Smith, D.W., Belosevic, Mike, and Chandrakanth, M.S., 2002, Use of Bacillus subtilis spores as model microorganisms for ozonation of Cryptosporidium parvum in drinking water treatment: Journal of Environmental Engineering Science, v. 1, p. 173-186.

Crane, S.R., Moore, J.A., Grismer, M.E., and Miner, J.R., 1983, Bacterial pollution from agricultural sources-A review: Transactions of the American Society of Agricultural Engineers, v. 26, no. 3, p. 858-866.

Davies-Colley, R.J, Bell, R.J., and Donnison, A.M., 1994, Sunlight inactivation of enterococci and fecal coliforms in sewage diluted seawater: Applied Environmental Microbiology, v. 60, no. 6, p. 2049-2058.

Davis, R. K., 1992, The waters edge: Hydrochemical interactions between the Platte River and the Lincoln Municipal Well Field, Ashland, Nebraska: Lincoln, Nebr., University of Nebraska, Ph.D. dissertation, 245 p., 58 figs.

DiGiorgio, C.L., Gonzalez, D.A., and Huitt, C.C., 2002, Cryptosporidium and Giardia recoveries in natural waters using Environmental Protection Agency Method 1623: Applied and Environmental Microbiology, v. 68, no. 12, p. $5952-5955$.

Edberg, S.C., LeClerc, Henri, and Robertson, John, 1997, Natural protection of spring and well drinking water against surface microbial contamination. II. Indicators and monitoring parameters for parasites: Critical Reviews in Microbiology, v. 23 , no. 2 , p. 179-206. 
Ehrlich, Aline, 1995, Atlas of the inland-water diatom flora of Israel: Jerusalem, Geological Survey of Israel, Israel Academy of Sciences and Humanities, 166 p., 60 plates.

Epstein, Samue, and Mayeda, Toshiko, 1953, Variation of ${ }^{18} \mathrm{O}$ content of water from natural sources: Geochemica Cosmochimica Acta, v. 4, p. 213-224.

Facile, Nathalie, Barbeau, Benoit, Prévost, Michèle, and Koudjonou, Boniface, 2000, Evaluating bacterial aerobic spores as a surrogate of Giardia and Cryptosporidium inactivation by ozone: Water Research, v. 34, no. 12, p. 3238-3246.

Francy, D.S., Myers, D.N., and Metzker, K.D., 1994, Escherichia coli and fecal-coliform bacteria as indicators of recreational water quality: U.S. Geological Survey WaterResources Investigations Report 93-4083, 34 p.

Fujioka, R.S., and Yoneyama, B.S., 2001, Assessing the vulnerability of groundwater sources to fecal contamination: Journal of the American Water Works Association, v. 93, no. 8 , p. $62-71$.

Gollnitz, W.D., Clancy, J.L., and Garner, S.C., 1997, Reduction of microscopic particulates by aquifers: Journal of the American Water Works Association, v. 89, no. 11, p. 84-93.

Greeson, P.E., 1982, An annotated key to the identification of coumonly occurring and dominant genera of algae observed in the phytoplankton of the United States: U.S. Geological Survey Water-Supply Paper 2079, 138 p.

Griffin, D.W., Gibson, C.J. III, Lipp, E.K., Riley, Kelley, Paul, J.H. III, and Rose, J.B., 1999, Detection of viral pathogens by reverse transcriptase PCR and of microbial indicators by standard methods in the canals of the Florida Keys: Applied and Environmental Microbiology, v. 65, no. 9, p. 4118-4125.

Haack, S.K., Fogarty, L.R., and Wright, Christopher, 2003, Escherichia coli and enterococci at beaches in the Grand Traverse Bay, Lake Michigan-Sources, characteristics, and environmental pathways: Environmental Science and Technology, v. 37, no. 15, p. 3275-3282.

Hargesheimer, E.E., Lewis, C.M., and Yentsh, C.M., 1992, Evaluation of particle counting as a measure of treatment plant performance, in Proceedings of the American Water Works Association meeting, 1992, Denver, Colo., no. 90595 .
Heberer, Thomas, Verstraeten, I.M., Meyer, M.T., Mechlinski, Andy, and Reddersen, Kirsten, 2001, Occurrence and fate of pharmaceuticals during bank filtration-Preliminary results from investigations in Germany and United States, in R.W. Masters, Pharmaceuticals and endocrine disrupting chemicals - Emerging contaminants in drinking water: National Ground Water Association, 2d International Conference on Pharmaceuticals and Endocrine Disrupting Chemicals in Water, Minneapolis, Minnesota, October 9-11, 2001, Water Resources Update, The University Council on Water Resources, p. 4-17.

Hirose, Hiroyuki, and Yamagishi, Takaaki, eds., 1977, Illustrations of the Japanese fresh-water algae: Tokyo. Uchidarokakuho Publishers, 933 p.

Holt, J.G., Krieg, N.R., Sneath, P.H.A., Staley, J.T., and Williams, S.T., 1994, Bergey's manual of determinative bacteriology (9th ed.): Philadelphia, Pa., Lippincott Williams and Wilkins, $787 \mathrm{p}$.

Huck, P.M., Coffey, B.M., Emelko, M.B., Maurizio, D.D., Slawson, R.M., Anderson, W.B., Van den Oever, John, Douglas, I.P., and O'Melia, C.R., 2002, Effects of filter operation on Cryptosporidium removal: Journal of the American Water Works Association, v. 94, no. 6, p. 97-110.

International Association for Water Pollution Research and Control Study Group on Health Related Water Microbiology, 1991, Bacteriophages as model viruses in water quality control: Water Research, v. 25, no. 5, p. 529-545.

Kistemann, Thomas, Claßen, Thomas, Koch, Christoph, Dangendorf, Frederike, Fischeder, Regine, Gebel, Juergen, Vacata, V., and Exner, Martin, 2002, Microbial load of drinking water reservoir tributaries during extreme rainfall and runoff: Applied and Environmental Microbiology, v. 68, no. 5 , p. 2188-2197.

Kudo, R.R., 1966, Protozoology (5th ed.): Springfield, Illinois, Charles C. Thomas Publisher, 1,172 p.

Larson, M.A., and Mariñas, B.J., 2003, Inactivation of Bacillus subtilis spores with ozone and monochloramine: Water Research, v. 37, no. 4, p. 833-844.

LeChevallier, M.W., and Norton, W.D., 1992, Examining relationships between particle counts and Giardia, Cryptosporidium, and turbidity: Journal of the American Water Works Association, v. 84, no. 12, p. 54-60.

LeChevallier, M.W., Norton, W.D., and Lee, R.G., 1991a, Occurrence of Giardia and Cryptosporidium in surface water supplies: Applied and Environmental Microbiology, v. 57 , no. 9 , p. $2610-2616$. 
LeChevallier, M.W., Norton, W.D., and Lee, R.G., 1991b, Giardia and Cryptosporidium spp. in filtered drinking water supplies: Applied and Environmental Microbiology, v. 57, no. 9 , p. 2617-2621.

Lee, J.J., Hutner, S.H., and Bovee, E.C., eds., 1985, An illustrated guide to the protozoa: Lawrence, Kansas, Society of Protozoologists, 629 p.

Lewis, A.D., and Manz, D.H., 1991, Light-scatter particle counting-Improving filtered-water quality: Journal of Environmental Engineering-American Society of Civil Engineers, v. 117, no. 2, p. 209-223.

Mau, D.P., and Pope, L.M., 1999, Occurrence of fecal coliform bacteria in the Cheney Reservoir watershed, southcentral Kansas, 1996-98: U.S. Geological Survey Fact Sheet 170-99, 4 p.

Medema, G.J., Bahar, M., and Schets, F.M., 1997, Survival of Cryptosporidium parvum, Escherichia coli, faecal enterococci and Clostridium perfringens in river waterInfluence of temperature and autochthonous microorganisms: Water Science and Technology, v. 35, no. 11-12, p. 249-252.

National Agricultural Statistics Service, 2004, Nebraska agricultural rank and agribusiness facts: Lincoln, Nebraska, U.S. Department of Agriculture, $4 \mathrm{p}$.

Nieminski, E.C., and Ongerth, J.E., 1995, Removing Giardia and Cryptosporidium by conventional treatment and direct filtration: Journal of the American Water Works Association, v. 87 , no. 9 , p. 96-106.

Nnadi, F.N., and Fulkerson, Mark, 2002, Assessment of groundwater under direct influence of surface water: Journal of Environmental Science and Health, Part A-Toxic/ Hazardous Substances and Environmental Engineering, v. A37, no. 7, p. 1209-1222.

O’Shaughnessy, P.T., Barsotti, M.G., Fay, J.W., and Tighe, S.W., 1997, Evaluating particle counters: Journal or the American Water Works Association, v. 89, no. 12, p. 60-70.

Page, F.C., 1976, An illustrated key to freshwater and soil amoebae: The Ferry House, Ambleside, United Kingdom, Freshwater Biology Association Scientific Publication No. 34, 155 p.

Pirkey, K.D., and Glodt, S.R., 1998, Quality control at the U.S. Geological Survey National Water Quality Laboratory: U.S. Geological Survey Fact Sheet 026-98, accessed September 17, 2004, at http://nwql.usgs.gov/Public/pubs/ QC_Fact/text.html

Prescott, G.W., 1978, How to know the freshwater algae: Dubuque, Iowa, Wm. C. Brown Company Publishers, 293 p.
Protist Information Server, 2005a, Selenastrum: Protist Information Server, accessed June 2, 2005, at http://protist. i.hosei.ac.jp/PDB/Images/Chlorophyta/Selenastrum/

Protist Information Server, 2005b, Phacus: Protist Information Server, accessed June 2, 2005, at http://protist.i.hosei. ac.jp/PDB/Images/Mastigophora/Phacus/index.html

Protist Information Server, 2005c, Tabellaria: Protist Information Server, accessed June 1, 2005, at http://protist.i.hosei. ac.jp/PDB/Images/Heterokontophyta/Araphidineae/Tabellaria/index.html

Protist Information Server, 2005d, Chlorogonium: Protist Information Server, accessed June 1, 2005, at http://protist. i.hosei.ac.jp/PDB/Images/Chlorophyta/Chlorogonium/

Protist Information Server, 2005e, Euglena: Protist Information Server, accessed June 1, 2005, at http://protist.i.hosei. ac.jp/PDB/Images/Mastigophora/Euglena/

Rice, E.W., Fox, K.R., Miltner, R.J., Lytle, D.A., and Johnson, C.J., 1996, Evaluating plant performance with endospores: Journal of the American Water Works Association, v. 88, p. $122-130$.

Rose, J.B., Darbin, Hamid, and Gerba, C.P., 1988, Correlations of the protozoa, Cryptosporidium and Giardia, with water quality variables in a watershed: Water Science and Technology, v. 20, no. 11/12, p. 271-276.

Schulmeyer, P.M., 1994, Effect of the Cedar River on the quality of the ground-water supply for Cedar Rapids, Iowa: U.S. Geological Survey Water-Resources Investigations Report 94-4211, 68 p.

Sinton, L.W., Davies-Colley, R.G., and Bell, R.G., 1994, Inactivation of enterococci and fecal coliforms from sewage and meatworks effluents in seawater chambers: Applied Environmental Microbiology, v. 60, no. 6, p. 2040-2048.

Sobsey, M.D., Amanti, Adam, and Handzel, T.R., 1995, Detection and occurrence of coliphage indicator viruses in water, in 1995 Proceedings of the Water Quality Technology Conference, American Water Works Association, November 1995, New Orleans, La., p. 2087-2097.

Thompson, J.E., and Blatchley, E.R. III, 2000, Gauma irradiation for inactivation of C. parvum, E. coli, and coliphage MS-2: Journal of Environmental Engineering-American Society of Civil Engineering, v. 126, no. 8, p. 761-768.

Trimboli, Peter, Lozier, J.C, and Johnson, Warren, 2001, Demonstrating the integrity of a large scale microfiltration plant using a Bacillus spore challenge test: Water Science and Technology_-Water Supply, v. 1, no. 5/6, p. 1-12. 
U.S. Environmental Protection Agency, 1992, Consensus method for determining groundwaters under the direct influence of surface water using microscopic particulate analysis (MPA): Washington D.C., U.S. Environmental Protection Agency, EPA 910/9-92-029, 60 p.

U.S. Environmental Protection Agency, 2001a, Method 1623 - Cryptosporidium and Giardia in Water by Filtration/ IMS/FA: Washington D.C., U.S. Environmental Protection Agency, EPA-821-R-01-025, 30 p.

U.S. Environmental Protection Agency, 2001b, Method 1602 - Male-specific $(\mathrm{F}+)$ and somatic coliphage in water by single agar layer (SAL) procedure: Washington D.C., U.S. Environmental Protection Agency, EPA 821-R-01-029, $30 \mathrm{p}$.

U.S. Environmental Protection Agency, 2002, Long Term 1 Enhanced Surface Water Treatment Rule-A quick reference guide: Washington D.C., U.S. Environmental Protection Agency, EPA 816-F-02-001, 2 p.

U.S. Geological Survey, 1997-2004, National field manual for the collection of water-quality data: U.S. Geological Survey Techniques of Water-Resources Investigations, book 9, chaps. A1-A9, accessed September 17, 2004, at http://pubs. water.usgs.gov/twri9A. Chapters were originally published during 1997-1999; updates and revisions are ongoing and are suumarized at http://water.usgs.gov/owq/FieldManual/ mastererrata.html

U.S. Geological Survey, 2004, Organic blind sample project, method performance data for organic analyses: U.S. Geological Survey National Water Quality Laboratory, accessed September 17, 2004, at http://bqs.usgs.gov/OBSP/intro.html

Verstraeten, I.M., Atkeson, R.L., and Stanton, C.P., 1998, Selected surface-water, ground-water, and tracer data from the Elkhorn and Platte Rivers and the alluvium near Ashland, Eastern Nebraska, 1991-1997: U.S. Geological Survey Open-File Report 98-396, 65 p.

Verstraeten, I.M., Carr, J.D., Steele, G.V., Thurman, E.M., Meyer, M.T., and Dormedy, D.F., 1999, Surface-water/ ground-water interaction-Herbicide transport into municipal collector wells: Journal of Environmental Quality, v. 28, no. 5 , p. 1396-1405.

Verstraeten, I.M., and Heberer, Thomas, 2002, Organic chemical removal issues, in Ray, Chittaranjan, Melin, Gina, and Linsky, R.B., eds., 2002, Riverbank filtration - Improving source water quality: Dordrecht, The Netherlands, Kluwer Academic Publishers, p. 321-330.
Verstraeten, I.M., Heberer, Thomas, and Scheytt, Traugott, 2002, Occurrence, transport, and fate of pesticides, pharmaceuticals, industrial products, and personal care products at river bank filtration sites, in Ray, Chittaranjan, Melin, Gina, and Linsky, R.B., eds., Riverbank filtration - Improving source water quality: Dordrecht, The Netherlands, Kluwer Academic Publishers, p. 175-227.

Verstraeten, I.M., Thurman, E.M., Lee, E.C., and Smith, R.D., 2002, Changes in concentrations of triazine and acetamide herbicides by bank filtration, ozonation, and chlorination in a public water supply: Journal of Hydrology, v. 266, no. 3-4, p. 190-208.

Verstraeten, I.M., Heberer, Thomas, Vogel, J.R., Speth, Thomas, Zuehlke, Sebastian, and Duennbier, Uwe, 2003, Overview of occurrence of endocrine-disrupting and other wastewater compounds during water treatment with case studies from Lincoln, Nebraska (USA), and Berlin, Germany, in Adams, Craig, and Bhandari, Alok, eds., 2003, Endocrine disrupting chemicals in the environment, American Society of Civil Engineers, Practice Periodical of Hazardous, Toxic, and Radioactive Waste Management, v. 7 , no. 4 , p. 253-263.

Vilanova, X., Manero, A., Cerdà-Cuéllar, M., and Blanch, A.R., 2002, The effect of a sewage treatment plant effluent on the faecal coliforms and enterococci populations of the reception river waters: Journal of Applied Microbiology, v. 92 , no. 2 , p. 210-214.

Vogel, J.R., Verstraeten, I.M., Coplen, T.B., Furlong, E.T., Meyer, M.T., and Barber, L.B., 2005, Occurrence of selected pharmaceutical and non-pharmaceutical compounds and stable hydrogen and oxygen isotope ratios in a riverbank filtration study, Platte River, Nebraska, 2001 to 2003, Volume 1: U.S. Geological Survey Data Series 117, $64 \mathrm{p}$.

Weiss, W.J., Bouwer, E.J, Ball, W.P., O’Melia, C.R., LeChevallier, M.W., Arora, Harish, and Speth, T.F., 2003, Riverbank filtration - Fate of DBP precursors and selected microorganisms: Journal of the American Water Works Association, v. 95, no. 10, p. 68-81. 


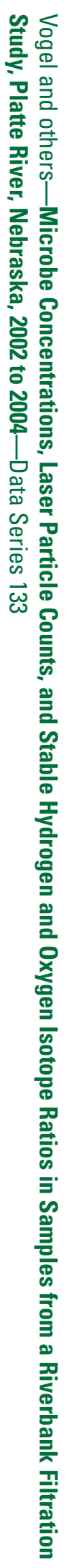

8 Printed on recycled paper 